\author{
Божо Б. ЋОРИЋ \\ Филолошки факултет \\ Универзитета у Београд
}

\title{
НОВИ ПРИЛОГ БИБЛИОГРАФИЈИ ТВОРБЕ РЕЧИ
}

\section{1. Увод}

Код Срба се писано стваралаштво, које се може пратити од краја дванаестог века, одвијало у виду диглосије (српскословенски и српски народни језик до 18. века), а касније и триглосије (рускословенски, српски народни језик и тзв. славеносрпски, нека врста лингвоамалгама) у 18. и првој половини 19. века. Оваква језичка ситуација разрешена је тако што је рускословенски задржан као сакрални језик, славеносрпски је сасвим истиснут, а функцију књижевног језика добија српски народни језик. Ову својеврсну језичку револуцију, као што је познато, извео је Вук Стефановић Караџић.

Да би свој тип језика што боље позиционирао у односу на друга два споменута конкурента, Вук је публиковао, у кратком року, граматику (исп. Вук Стефановић, Писменица сербскога језика по говору простога народа, Беч, 1814) и речник, са преко 26000 одредница (исп. Вук Стефановић, Српски рјечник истолкован њемачким и латинским ријечима, Беч, 1818). Ова лексичка грађа, која првенствено потиче из ауторовог завичајног дијалекта, послужиће као база за једну од првих дериватолошких студија српског језика: у њој су представљене суфиксална и композициона творба именица и придева (исп. Вук Стефановић Караџић, Главна свршивања суштествителни и прилагателни имена у српском језику, Даница, Беч, 1828, 1-135), по узору на чешке граматике Јозефа Добровског (Josef Dobrovský). Грађа истог типа, али знатно обогаћена, са преко 47000 одредница (исп. Вук Стефановић Караџић, Српски рјечник истумачен њемачкијем и латинскијем ријечима, Беч, 1852), служиће, током 19. и 20. века, као база за граматичке, а у тим оквирима и творбене описе српског (српскохрватског) језика.

*coricbozo@gmail.com

** Ово је знатно проширена и обогаћена верзија библиографије објављене пре седам година. Исп. Ћорић Б. Божо, Прилог библиографији творбе речи, НССВД 42/3, 2013, 173-253. 
Током 19. века, у складу са оновременим трендом лингвистичке науке, предност су имала проучавања речи дијахроном методологијом, са главним циљем да се утврде основе и корени српског језика (Даничић 1876; Новаковић 1894).

На самом крају 19. века појавиће се граматика са опширним поглављем насловљеним творба речи: био је је то, до тада, најкомплетнији, могло би се рећи, синхрони опис творбе речи, базиран на корпусу Вука Стефановића Караџића (Maretić 1899). Исти корпус је, добрим делом, и у основи описа граматичког система српскохрватског језика на немачком језику: творба није описана скупно, већ посебно за именске речи (именице и придеве), посебно за глаголске (Leskien 1914). Први пут ће се у форми засебне књиге (као део универзитетских предавања из граматике), творба речи појавити у првој половини прошлог века: најпре слагање и деривација именица и придева (Белић 1931), а затим слагање и деривација готово свих врста речи (Белић 1949). Пола века након Лескинове граматике излази нова велика граматика, са опширним делом о творби речи, на бази свежије лексичке грађе (Стевановић 1964). И школске граматике садрже део о творби речи (исп. Brabec et al. 1952, Стевановић 1971, Barić et al. 1979, Barić et al. 2005, Silić, Pranjković

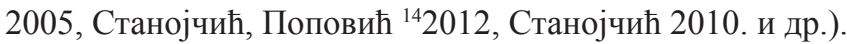

У 20. и 21. веку публиковано је више дериватолошких дела монографског карактера. Прве монографије биле су компаративно-историјски оријентисане (Белић 1901. и 1904; Бошковић 1936). Значајан део Бошковиће студије посвећен је тзв. именичкој моцији у јужнословенским језицима (суфиксалном начину творбе назива за бића женског пола према одговарајућим мушким еквивалентима). Управо та тема је касније, на грађи историјског речника, обрађена у посебној монографији (Ћорић 1982). У оквиру лингвоконтактологије описана је творба речи у српскохрватском језику под утицајем немачког (Rammelmeyer 1975). Крајем прошлог и почетком овог века излази неколико монографија у којима су предмет расправе, поред осталог, одређене творбено-семантичке категорије, као што су имена места, имена вршилаца радњи и имена оруђа (Киршова 1998. и 1999), поједини творбени начини у оквиру одређене врсте речи, као што је непрефиксална и несуфиксална творба именица (Barić 1980), префиксација код именица (Тешић 2002), разни аспекти творбе именица (Ћорић 2008), именички суфикси турског порекла (Радић 2001) и сл.

За проучавање творбе речи од великог значаја су лексикографска дела објављена током 20. и почетком 21. века, као што су: Речник српскохрватскога књижевног језика, I-VI (Нови Сад/Загреб, 1967, I-II; Нови Сад - Загреб, 1969, III; Нови Сад, 1971, IV; Нови Сад, 1973, V; Нови Сад, 1976, VI) и Речник српскохрватског књижевног и народног језика, 1-18, Београд, 1959-2010 (израда у току), етимолошки речник (Skok 1971-1974), једнотомни Речник српскога језика, Нови Сад 2007, атерго речници (Маtešić 1965-1967, Николић 2000), те речник творбених морфема (Шипка 2005) и др.

Значајно место у творби речи имају и две млађе синтетичке студије:

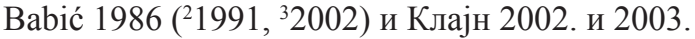


Публиковано је и више стотина већих или мањих студија, расправа и чланака у којима се обрађују различита теоретска и практична питања творбе речи.

\section{2. Библиографија}

Библиографија садржи научне и стручне радове о творби речи у временском распону од скоро два века (од 1828. године до наших дана). У њу су укључене монографије, студије, расправе, чланци, граматике, ситнији прилози, критике, прикази и сл. Главнина библиографских јединица прикупљена је из публикација са оног дела јужнословенског језичког простора који је у прошлости идентификован различитим глотонимима: српски језик, српскохрватски / хрватскосрпски језик, српски или хрватски, хрватски или српски, хрватски, и сл. Део података преузиман је и из публикација насталих ван тога простора, у разним славистичким центрима. Међу ауторима су, као што ће се видети, не само домаћи србисти (и/или сербокроатисти) већ и домаћи слависти других усмерења (русисти, полонисти, бохемисти, бугарсти и сл.), као и страни научници који су се бавили питањима српске, односно српскохрватске творбе речи. Библиографске јединице су поређане према азбучном реду презимена аутора (и онда кад је дело писано латиницом), а унутар тога према времену публиковања. Часописи који се јављају често дати су скраћено, ради уштеде у простору. У списку се налазе и све значајније граматике српског (и српскохрватског) језика у којима се творба (грађење) речи издваја као посебна целина (уз навођење пагинације). Нису изостављени ни радови контрастивне (конфронтативне) природе кад су у њима, у овом или оном обиму, аутори укључивали и феномене српске (српскохрватске) творбе речи. Библиографија садржи и радове у којима се анализира и грађа кајкавких и чакавских говора, уколико, по нашој процени, обрађена тематика има шири значај за проучавање творбе речи.

Библиографска грађа која следи од значаја је не само за српску науку о језику (којој је првенствено намењена), већ и за све друге научне центре који, у већој или мањој мери, баштине резултате истраживања у области творбе речи на централним јужнословенским просторима.

1. Аврамова Цветанка, Начини на назоваване на продукти от животински произход в българския и чешкия език (в съпоставка със сръбски),, ${ }^{1}$ CJ XIX, 2014, 307-315.

2. Ајџановић Милан, Синтагме с именицом типа потіna agentis као управним чланом, ППЈ 34, 2003, 51-80.

\footnotetext{
${ }^{1}$ Показује се да је суфиксална деривација продуката животињског порекла (кожа, месо/јело, мириси, фекалије) продуктивна у чешком и српском, а непродуктивна у бугарском. (Ауторка не даје потврде за прилике у српском језику, већ упућује на чланак: Ћорић Б. Божо, О дериватима са значењем производа животињског порекла у српском језику).
} 
3. Ајџановић Милан, Нови приступ именицама типа nomina agentis, ППЈ 36, 2005 , $157-171$

4. Ајџановић Милан, Семантичко-деривациона гнезда лексема селити, кћи, муж, син $u$ супруг, in: Гортан-Премк Даринка, Вера Васић и Рајна Драгићевић, Ceмантичко-деривачиони речник, св. 2, (Човек-унутрашњи органи и ткива, психофизиолошка стања, и радње, психофизичке особине, сродство), Филозофски факултет, Одсек за српски језик и лингвистику, Нови Сад, 2006.

5. Ајџановић, Милан, Корелативне предикације именица nomina attributiva, Лингвистичке свеске 6, Нови Сад, 2007, 72-83.

6. Ајџановић Милан, Корелативне предикаиије именииа nomina professionis, ППЈ 39, 2008, 211-218.

7. Ајџановић Милан, Функиионално оптерећење суфикса за обележавање особа, Нови Сад, 2008: Филозофски факултет.

8. Ајџановић Милан, Семантичко-деривациона анализа географских термина домаћег порекла, in: Зборник у част Гордани Вуковић. Лексикологија - Ономастика - Синтакса. Нови Сад: Филозофски факултет у Новом Саду, 2011, 319-330.

9. Ајџановић С. Милан, Деривациони потенцијал географских термина страног порекла, in: Творба речи и њени ресурси у словенским језицима, Зборник радова са четрнаесте међународне научне конференције Комисије за творбу речи при Међународном комитету слависта, Београд, 2012: Филолошки факултет, 437-451.

10. Ајџановић, Милан, Именице с обележјем [особа +$]$ у језику младих корисника интернета, in: Branko Tošović, Arno Wonisch (Hg.), Wortbildung und Internet: Institut für Slawistik der Karl-Franzens-Universität Graz, Kommission für Wortbildung beim Internationalen Slawistenkomitee, Graz, 2016, 13-26.

11. Ајџановић С. Милан, Семантичка дериваиија фитонима и зоонима у Ћопићевим делима, Зборник матице српске за књижевност и језик, LXIV/3, Нови Сад, 2016, 765-774.

12. Алановић Б. Миливој, Каузативно-манипулативни глаголи: деривационо мотивисане семантичке и аргументне варијащије, in: Творба речи и њени ресурси у словенским језицима, Зборник радова са четрнаесте међународне научне конференције Комисије за творбу речи при Међународном комитету слависта, Београд, 2012: Филолошки факултет, 453-467.

13. Албин Александар, Придевски суфикс -овит/-евит, ППЈ 7, 1971, 11-18.

14. Андрић Едита, Деривациони облищи речи nyelv/jезик, in: Граматика и лексика у словенским језицима (Зборник радова са научног симпозијума), Нови Сад - Београд, 2011, 339-350.

15. Андрић Ј. Едита, Деминутив у мађарском и српском језику, Зборник за језике и књижевности Филозофског факултета у Новом Саду, књ. I, Нови Сад, 2011, $11-26$.

16. Anić Vladimir, O pridjevima na -(a)n $i$-ljiv od istog korijena ili osnove, J VII, 1959, 111-113.

17. Анић Владимир, Род и спол у српскохрватском језику: разграничење, НССВД 13/1, 1984, 5-15.

18. Ančić Obradović Marija, Semantička i morfološka struktura imenica koje znače lica izvedenih pomoću sufiksa -ar, RFFS IV, 1966-1967, 207-228.

19. Ančić Obradović Marija, Izvedene imenice - I. Uključivanje značenja ili semantička kondenzacija, RFFS V, 1968-1969, 241-254.

20. Ančić Obradović Marija, Teorija tvorbe riječi i njena problematika, RFFS VII, 1973, $11-52$. 
21. Ančić Obradović Marija, Stvaralačke sposobnosti jezika u oblasti tvorbe riječi, KJ III/3-4, 1974, 47-57.

22. Анчић Обрадовић Марија, Суфиксална творба именица помоћу нулте суфиксаuије, KJ IV/1-2, 1975, 7-18.

23. Ančić Obradović Marija, Neki aspekti raščlanjivanja riječi, KJ IV/3-4, 1975, 7-15.

24. Ančić Obradović Marija, Položaj izvedenih imenica sa značenjem lica muškog roda u sistemu izvedenica sa značenjem predmeta, Radovi ANU BiH LV, 1975, 145-184.

25. Ančić Obradović Marija, Pitanja raščlanjivanja riječi s posebnim strukturnim karakteristikama, KJ V/1-2, 1976, 21-33.

26. Анчић Обрадовић Марија, Релативност појма мотивисаност - резултат комбинације обавезности и произвољности смисаоне везе између означитеља и означеног код изведених ријечи (Један аспекат односа између означитеља и означеног), KJ VI/2, 1977, 13-30.

27. Ančić Obradović Marija, Svojevrsna obaveznost veze između označitelja i označenog kod izvedenih riječi, KJ VII/3, 1978, 31-39.

28. Арсенијевић Нада, Један тип реификаиије у српском језику, ЗбМСФЛ LI/1-2, 2008, 67-74.

29. Arsenijević Boban, On two types of deadjectival nominal in Serbian, ${ }^{2}$ SL 70, 2010, 129-145.

30. Asbóth Oszkár, Magyar hatás horvát-szerb kutyanevekben?, Nyelvtudomány V, Budapest, 1915, 161-165. ${ }^{3}$

31. Auburger Leopold, Pregledna morfologija pravih glagolskih imenica hrvatskoga književnog jezika, J LXV/2-3, 59-75.

32. Бабић Биљана, Семантика префикса до- (као првог) у глаголском префиксалу, ППЈ 39, 2008, 275-315.

33. Бабић Биљана, Имениче изведене суфиксима турског поријекла у Андрићевим приповијеткама - грачки опус, in: Branko Tošović (ur.), Das Grazer opus von Ivo Andrić (1923-1924), Graz, 2010: Institut für Slavistik der Karl-Frasnzens-Universität Graz/Beogradska knjiga Beograd, 311-318.

34. Babić Vladimir, Vlastelin i njegove izvedenice, J IX/ 5, 1961-1962, 133-137.

35. Babić Vlado, Staje za stoku i živinu, HJ III, 1935, 176-180.

36. Бабић Милица, Nomina agentis изведена суфиксом -ло, HJ XVI, 1967, 84-92.

37. Babić Stjepan, Neka pitanja u vezi s imenicama na -ost, J IV/5, 1956/57, 145-148.

38. Babić Stjepan, ,Žigosani sufiks -telj”, J X/4, 1962-1963, 113-116.

39. Babić Stjepan, Pridjevski sufiks $i$-an $i$-anî, -en $i$-enî, J X/5, 1962-1963, 137-143.

40. Babić Stjepan, Pridjevi od imenice nafta, J XI/5, 1964, 157-159.

41. Babić Stjepan, Sufiksalna tvorba pridjeva u suvremenom hrvatskom ili srpskom književnom jeziku, Rad JAZU 344, 1966, 63-256.

42. Babić Stjepan, Sporni sufiks -telj, J XV/3, 1968, 69-76.

43. Babić Stjepan, Tvorba imenica na -ić, J XVII/3, 1970, 74-89; XVII/4, 1970, 112-121.

44. Babić Stjepan, Tvorba imenica na -če, КњJ XVII/2, 1970, 202-207.

45. Babić Stjepan, Tvorba imenica na -ač, RZSF 12, 1971, 13-20.

46. Babić Stjepan, Izvedenice sufiksom -ica od imeničkih osnova, J XIX/4-5, 1972, 109-123.

47. Babić Stjepan, Klima-uređaj, klima-postrojenje, J XX/2, 1972, 63.

48. Babić Stjepan, Sustav u tvorbi hrvatskih umanjenica, Slavistična revija XX, Ljubljana, 1972, 19-28.

\footnotetext{
${ }^{2} \mathrm{O}$ деадјективној номинализацији помоћу суфикса -ост.

${ }^{3}$ Оспорава Лескиново мишљење да је суфикс -ов у именима паса као гаров, белов, шаров мађарског порекла.
} 
49. Babić Stjepan, Tvorba imenica sufiksom -telj, J XXI/1, 1973, 6-12.

50. Babić Stjepan, Tvorba imenica sa završetkom -ica $i$-ice, RZSF 13, 1973, 37-60.

51. Babić Stjepan, Odnos izvedenica sa -telj $i$-lac, J XXI/3-4, 1974, 90-95.

52. Babić Stjepan, Suvremeni problemi tvorbe riječi, J XXIII/2, 1975, 41-47.

53. Babić Stjepan, Tvorba mjesnih imenica u suvremenom hrvatskom književnom jeziku, Zbornik Zagrebačke slavističke škole, II/ 2, Zegreb, 1974, 151-170.

54. Babić Stjepan, Prezimena, toponimi, etnici, ktetici u književnom jeziku, J XXIII/5, 1976, 139-144.

55. Babić Stjepan, Tvorba etnika u dijalektima i u hrvatskom književnom jeziku, Onomastica Jugoslavica 6, Zagreb, 1976, 145-185.

56. Babić Stjepan, Tvorba imenica sufiksima na -ak, RZSF 14, 1976, 69-77.

57. Babić Stjepan, Sustav u tvorbi imenica muškoga roda koje znače vršitelja radnje (nomina agentis), RZSF 15, 1977, 11-18.

58. Babić Stjepan, Mješovite tvorenice, J XXV, 5, 1978, 129-138.

59. Babić Stjepan, Tvorba imenica sufiksima na -(a)k, KJ VII/4, 1978, 19-26.

60. Бабић Сtјепан, Творба именица суфиксима на -(а)ц, НJ XXIII, 1978, 175-186.

61. Babić Stjepan, Granica između tvorbenih i netvorbenih (motiviranih i nemotiviranih) riječi, Prilozi - VIII međunarodni slavistički kongres, Zagreb, 1978, 7-14.

62. Babić Stjepan, Tvorba samostalnikov s priponskimi obrazili na -ka, SR XXVI/4, 1978, 391-402.

63. Babić Stjepan, Iterativizacija i srodne pojave u tvorbi glagola, F 8, 1978, 37-48.

64. Babić Stjepan, Rad na Rječniku naseljenih mjesta i njihovih etnika i ktetika, Bilten zavoda za lingvistiku 3, Zagreb, 1979, 38-40.

65. Babić Stjepan, Sufiksi s morfemskoga gledišta, J XXVII/1, 1979, 10-13.

66. Babić Stjepan, Tvorba imenica sufiksima na -stvo, F 9, 1979, 155-167.

67. Babić Stjepan, Kako se kaže kad je žena sudac?, J XXVII/2-3, 1979-1980, 86-87.

68. Babić Stjepan, Tvorba imenica sufiksima na -aš, J XXVIII/2, 1980, 33-44.

69. Babić Stjepan, Tvorba imenica sufiksima na -ar, F 10, 1980-1981, 141-150.

70. Babić Stjepan, Tvorba imenica nultim sufiksima, Bilten Zavoda za lingvistiku 4, Zagreb, 1981, 4-52.

71. Babić Stjepan, Koliko ima sufiksa u imeničkoj tvorbi?, J XXVIII/5, 1981, 146-148.

72. Babić Stjepan, Dieselov ili dizelski motor?, J XXIX/2, 1981, 61-62.

73. Babić Stjepan, Tvorba imenica sufiksima na -ina, Rad JAZU 388, 1981, 313-335.

74. Babić Stjepan, Sustav u mocijskoj tvorbi u suvremenom hrvatskom književnom jeziku, Slavica Helvetica, Bern, 1981, 16, 33-46.

75. Babić Stjepan, Njemačke prevedenice u hrvatskom ili srpskom jeziku, in: Лексикографија и лексикологија, Нови Сад-Београд, 1984: Матица српска, 9-14.

76. Babić Stjepan, Blatan, prašan ili blatnjav, prašnjav?, J XXXIII/2, 1985, 57-58.

77. Babić Stjepan, Tvorba riječi u hrvatskom književnom jeziku, Nacrt za gramatiku, Djela JAZU 62, Zagreb, 1986: JAZU - GLOBUS.

78. Babić Stjepan, Sustav u sufiksalnoj tvorbi glagola, KJ 15/2, 1986, 97-105.

79. Babić Stjepan, Vrste riječi i preobrazba, F 16, 1988, 25-33.

80. Babić Stjepan, Sinkronija i dijakronija u tvorbi riječi, J XXXVI/1, 1989, 1-9.

81. Babić Stjepan, Katolkinja ili katolikinja?, J XXXVII/2, 1989, 59-60.

82. Бабић Стјепан, Постанак нових назива, НССВД 18/1, 1990, 31-37. ${ }^{4}$

83. Babić Stjepan, Tvorba riječi u hrvatskom književnom jeziku, Nacrt za gramatiku, Djela JAZU 62, Zagreb, ${ }^{2}$ 1991: HAZU - GLOBUS.

\footnotetext{
${ }^{4}$ Између осталог и о настанку једночланих назива творбеним путем.
} 
84. Babić Stjepan, Sufiksalna tvorba uvećanica u hrvatskome književnome jeziku, SL 22, 1-2 (41-42), 1996, 11-20.

85. Babić Stjepan, Je li kuhar korijenita riječ?, J 44/4, 1997, 149-151.

86. Babić Stjepan, Dva tvorbena normativna problema i njihova rješenja, J 46/3, 1999, 104-112.

87. Babić Stjepan, Tip artistica kao normativni problem, J 46/4, 1999, 142-144.

88. Babić Stjepan, Ženska zanimanja u hrvatskome bibliografskome leksikonu, J 46/5, 1999, 191-193.

89. Babić Stjepan, Tvorba riječi u hrvatskome književnome jeziku, Velika hrvatska gramatika, knjiga druga, Zagreb, ${ }^{32} 2002$, HAZU - Nakladni zavod Globus.

90. Балтова Юлия, Улога творбеног значень код дефинисања изведених речи у једнојезичком описном речнику, НССВД 26/2, 1997, 339-342.

91. Балтова Миньова Юлия, За така наречените „неокласицизми” като ресурс в съвременното словообразуване, in: Творба речи и њени ресурси у словенским језицима, Зборник радова са четрнаесте међународне научне конференције Комисије за творбу речи при Међународном комитету слависта, Београд 2012: Филолошки факултет, 43-51.

92. Балтова Юлия, Признакът пол и неговото място в значениото и формата на производните nomina personalia, ${ }^{5}$ CJ XIX, 2014, 317-324.

93. Барако Татјана, Прилог познавању сложеница у српскословенском језику, ППЈ 30-32, 1999-2001, 71-76.

94. Barac Grum Vida, Patronimička prezimena u SRH, Onomastica Jugoslavica 10, Zagreb, 1982, 3-5.

95. Barac Grum Vida, Zečević Vesna, Tvorba prezimena u Gorskom kotaru, ČJOK, 217-224.

96. Barić Eugenija, Šivenje ili šivanje, J XXIII, 2, 1975, 59-60.

97. Barić Eugenija, Malić Dragica, O problemu polusloženica, Radovi III, Institut za jezik i književnost u Sarajevu, Odjeljenje za jezik, Sarajevo, 1976, 245-258.

98. Barić Eugenija, Malić Dragica, O problemu polusloženica, J XXIV, 3-4, 1976/7, 90-104.

99. Barić Eugenija, Dosadašnje proučavanje složenica u hrvatskom i srpskom jeziku, RZJ 4-5, 1979, 17-29.

100. Barić Eugenija et al., Priručna gramatika hrvatskoga književnog jezika, ${ }^{6}$ Zagreb, 1979: Školska knjiga.

101. Barić Eugenija, Imeničke složenice neprefiksalne i nesufiksalne tvorbe, Zagreb, 1980: Hrvatsko filološko društvo.

102. Barić Eugenija, Imeničke složenice s glagolskim prvim dijelom, RZJ 6-7, 1982, 17-30.

103. Barić Eugenija, Tvorenice s elementom sve-, RZJ 10-11, 1985, 55-64.

104. Барић Еугенија/Лукенда Марко, Придјевске творенице у вишечланих термина, KJ 15/2, 1986, 107-116.

105. Barić Eugenija, Mocijski parnjaci i njihova upotreba, RZJ 13, 1987, 9-18.

\footnotetext{
${ }^{5} \mathrm{O}$ проблему родно-полне рвноправности. Истичу се три аспекта истраживања: системскијезичко (творбена анализа), сочиолингвистички (проблем феминизације на друштвеном плану, језичка дискриминација), нормативно-кодификацијски. У центар пажње стављен је системскојезички аспект: проблеми повезани са афиксалним и аналитичким начином језичке номинације. Апострофира се потреба разграничења nomina personalia од тзв. „статусних” назива (титула, звања, професија, занимања и сл.). Нпр. реч лекар поседује обележје персоналност, а неутрална је с обзиром на пол, тј. изведеницу карактерише опити род. Nomina feminativa садржи обележје пол које је на језичком плану изражено формантом -ка. Обележје маскулативност нема свој формални израз, па се језичка структура представља као лекар-+Ø, тј. изведеница садржи нулти суфикс.

${ }^{6}$ Творба речи 219-303. Исп. и каснија издања (са коригованим насловима)
} 
106. Barić Eugenija, Kada sudac a kada sutkinja?, J XXXV/3, 1988, 85-88.

107. Barić Eugenija, Mocijska tvorba i pogledi Radosava Boškovića, Први лингвистички научни скуп у спомен на Радосава Бошковића, (Даниловград 1987), ЦАНУ књ. 17, Одјељење умјетности, књ. 6, Титоград, 1988, 157-164.

108. Barić Eugenija, Tvorbeni status ženskog mocijskog parnjaka, RZJ 14, 1988, 43-49.

109. Barić Eugenija, Ženski mocijski parnjak kao funkcionalna komunikacijska kategorija, J XXXVII/1, 1989, 12-21.

110. Barić Eugenija et al., Hrvatska gramatika, ${ }^{7}$ Zagreb, ${ }^{4} 2005$ : Školska knjiga.

111. Баук Снежана, Семантика и творбени елементи једне класе драгачевских онимa ${ }^{8}$ Пети лингвистички скуп „Бошковићеви дани”, Подгорица, 2003, 339-345.

112. Башановић Чечовић Јелена, Семантичке и творбене карактеристике глагола бастати у ирногорском језичком изразу, ${ }^{9}$ Осми лингвистички скуп „Бошковићеви дани", ЦАНУ, Подгорица 2012, 163-175.

113. Basić Nataša, Pridjevi na -ći glagolskog postanja u hrvatskim rječnicima,${ }^{10} \mathrm{~F} 30-31$, 1998, 155-170.

114. Beard Robert Earl, The Suffixation of Adjectives in Contemporary Literary SerboCroatian, PhD dissertation, The University of Michigen, Ann Arbor, 1966.

115. Belaj Branimir/Buljan Gabrijela, The polysemy of the Croatian verbal prefix od- ${ }^{11}$ Review of Cognitive Linguistics (1877-9751) 14/2 2016, 337-384.

116. Belić Alexander, Zur Entwicklungsgeschichte der slavischen Deminutiv- und Amplificativsuffixe, 1. Die Substantiva, Archiv für slavische Philologie XXIII, Berlin, 1901, 134-206. (Прештампано у преводу на српски: Александар Белић, O историјском развитку словенских деминутивних и амплификативних суфикса, 1. Именице, у: Уроредна словенска линgвистика 1, Изабрана дела Александра Белића, том 2, Завод за уџбенике и наставна средства, Београд, 2000, 9-54).

117. Belić Alexander, Zur Entwicklungsgeschichte der slavischen Deminutiv- und Amplificativsuffixe, 2. Die Adjectiva, Archiv für slavische Philologie XXVI, Berlin, 1904, 321-357. (Прештампано у преводу на српски: Александар Белић, O историјском развитку словенских деминутивних и амплификативних суфикса, 2. Придеви, у: Упоредна словенска лингвистика 1, Изабрана дела Александра Белића, том 2, Завод за уџбенике и наставна средства, Београд, 2000, 55-76).

118. Белић А[лександар], Двојица, неколицина и слична образоваға, ЈФ III, 1922/1923, 79-81. (Прештампано у: О различитим питањима савременог јези$\kappa a$, Изабрана дела Александра Белића, том 13, Београд, 2000: Завод за уџбенике и наставна средства, 136-138).

119. Белић Александар, Српски језик: образовање речи - сложенице и суфикси, ${ }^{12}$ Београд, 1931: Литографија.

120. Белић А[лександар], $O$,, частољубљу”, ${ }^{13} \mathrm{HJ} \mathrm{I}, 1933,12-15$.

121. Белић А[лександар], $O$ „,светогледу”, НJ I, 1933, 43-47.

122. Белић А[лександар], О стварану нових речи, НJ I, 1933, 72-76.

\footnotetext{
${ }^{7}$ Творба речи 285-389.

${ }^{8}$ На материјалу локалног говора анализирају се, поред осталог, изведени називи за овце, краве и козе типа Белица, Рогуща, Шарица и сл.

${ }^{9}$ Поред осталог и о дериватима са основом од глагола бастати.

${ }^{10} \mathrm{y}$ раду се расправља о двема скупинама девербалних придева на -ћu: у првој скупини пред суфиксалним -ћй су форманти -е- и -у-, а у другој је тамо формант -а-.

${ }^{11} \mathrm{O}$ полисемији префикса од- из перспективе когнитивне граматике.

12 Литографисана предавања о сложеницама и изведеницама.

${ }^{13}$ Мање о творбеном, више о лексичком значењу ове лексеме.
} 
123. Белић А[лександар], О грађењу глаголских именица на -ње $u$-ће, $\mathrm{Hj}$ I, 1933, 262-268.

124. Б[елић] А[лександар], О грађењу нових речи, HJ IV, 1936, 129-131, ${ }^{14} 161-165,{ }^{15}$ $193-197,{ }^{16} 225-232,{ }^{17} 257-264 .{ }^{18}$

125. Б[елић]А[лександар], Радосав Бошковић, Развитак суфикса у јужнословенској језичкој заједници, 1936, 1-155, ЈФ XV, 232-246.

126. Б[елић] А[лександар], Из живота речи, НJ VI/7-8, 1939, 177-201.

127. Белић Александар, Савремени српскохрватски књижевни језик II, Наука о грађењу речи, Београд, 1949: Народна књига. (Прештампано у: Универзитетска предавања из савременог српскохрватског језика/Библиографија радова Александра Белића, Изабрана дела Александра Белића, том 14, Београд, 1999: Завод за уџбенике и наставна средства, 93-213).

128. Белић Александар, „Депрефиксащија” у словенским језищима, ЈФ XVIII/1-4, 1950, 87-101. (Прештампано у: Упоредна словенска лингвистика, Изабрана дела Александра Белића, том 2, Београд, 2000: Завод за уџбенике и наставна средства, 493-503).

129. Белић А[лександар], О сложеницама, $\mathrm{Hj}$ I, 1950, 169-177. (Прештампано у: $O$ различитим питањима савременог језика, Изабрана дела Александра Белића, том 13, Београд, 2000: Завод за уџбенике и наставна средства, 252-257).

130. Белић Александар, $O$ префиксима и наставцима (предавање на лингвистичком састанку 12. XII 1952), Глас САНУ IV/2, 1952, 325-326. (Прештампано у: $O$ различитим питањима савременог језика, Изабрана дела Александра Белића, том 13, Београд, 2000: Завод за уџбенике и наставна средства, 251).

131. Белић Александар, Југославија и сродне изведене речи, НJ III, 1952, 287-290.

132. Белић А[лександар], Природа и происхождение существительных субъективной оченки, ЈФ XXII, 1957-1958, 131-139.

133. Белић Александар, О језичкој природи и језичком развитку (лингвистичка испитивања), І књига, Београд, 1958: Нолит.

134. Белић Александар, О језичкој природи и језичком развитку (лингвистичка испитивања), ІІ књига, Београд, 1960: Нолит.

135. Белић Александар, О историјском развитку словенских деминутивних и амплификативних суфикса. Природа и порекло именица субјективне оцене, ${ }^{19}$ Упоредна словенска лингвистика 1, Изабрана дела Александра Белића, Београд, 2000, 9-81.

136. Берисављевић Светлана, Језик и пол: титуле и занимања жене у бании, ППЈ 22 , 1986, 119-133.

137. Бечева Ничка, О дублетности код деминутива и аугментатива у савременом сриском језику, НССВД 29/1, 2000, 197-202.

138. Биговић Глушица Рајка, Специфични случајеви творбе придјева у језику ирногорских писаиа XIX вијека (придјеви на -ћu), Четврти лингвистички скуп „Бошковићеви дани", ЦАНУ, Подгорица, 1999, 89-96.

\footnotetext{
${ }^{14}$ Кратак критички осврт на студију Вука С. Караџића, Главна свршивања суштествителни и прилагателни имена у српском језику, Даница, Беч, 1828, 1-135.

${ }^{15}$ Сматра да су лоше начињене речи као водопад, дрворед, пароброд, градоначелник и сл.

${ }^{16}$ Позитивно оцењује изведенице на -ач, које је Вук С. Караџић начинио сам при преводу Новог завета.

${ }^{17} \mathrm{O}$ изведеницама на -лац (типа просилач) и -ач (викач).

${ }^{18}$ Говори се, са пуристичких позиција, о неким речима које је Вук С. Караџић сам начинио.

${ }^{19}$ Превод радова истог аутора објављених у часопису Archiv für slavische Philologie XXIII и Archiv für slavische Philologie XXVI.
} 
139. Bidwell Charles, Two Morpho-syntactic Patterns in Serbo - Croatian, Language 45/1, 1969, 31-34.

140. Birtić Matea, Unutarnja struktura odglagolskih imenica u hrvatskome jeziku, Zagreb, 2008: Institut za hrvatski jezik i jezikoslovlje.

141. Бјелаковић Г. Исидора, Однос ендоцентричних и егзочентричних именичких сложенииа у географској терминологији Срба 18. и 19. века (1783-1867), 3бМСФЛ ХІХ/2, 1976, 7-11.

142. Бјелаковић Г. Исидора, Именичке сложенице у предстандардној фази развоја српског језика (географска терминологија), in: Творба речи и њени ресурси у словенским језицима, Зборник радова са четрнаесте међународне научне конференције Комисије за творбу речи при Међународном комитету слависта, Београд, 2012: Филолошки факултет, 469-484.

143. Bjelanović Živko, Fonološka i morfološka uvjetovanost tvorbe etnika sufiksom -anac, J XXII/3, 1975, 72-80.

144. Bjelanović Živko, Imena stanovnika mjesta Bukovice, Split, 1978: Čakavski sabor.

145. Bjelanović Živko, Semantičke podudarnosti nadimaka na -onja $i$-ilo, ČJOK, 235-246.

146. Bjelanović Živko, Tvorba hipokoristika sufiksalne forme u jekavskim govorima sjeverne Dalmacije, Onomastica Jugoslavica 10, Zagreb, 1982, 7-15.

147. Bjelanović Živko, Tvorbeni prsten kao model opisa antroponomastičkih tvorenica, F 24/25, 1995, 61-68.

148. Bjelanović Živko, Antroponimija Bukovice, Split 1988: Književni krug.

149. Бјелановић Живко, О моделима описа презимена и обитељских надимака на -ић $u$-овић/-евић, НССВД 20/2, 381-390.

150. Bjelanović Živko, Tvorbeni i prozodemski sustav prezimena tipa Dragović, FOC 12-13, 2003/4, 75-90.

151. Bjelanović Živko, Hipokoristik kao oznaka za tvorbeni način i kao oznaka za vrstu riječi, FOC 15, 2006, 1-14.

152. Bjelanović Živko, Onomastičke teme, Zagreb, 2007: Hrvatska sveučilišna naklada.

153. Бјелетић Марта, О неким експресивним глаголским префиксима, in: Говори призренско-тимочке области и суседних дијалеката, Зборник са научног скупа, Ниш, 1994, 351-358.

154. Бјелетић Марта, Из експресивне префиксащије: кочоперити се, ЈФ LVI/1-2, 2000, 109-124.

155. Бјелетић Марта, Исковрнути глаголи: Типови експресивних превербалних форманата, Београд, 2006: ИСЈ САНУ.

156. Бјелетић Марта, Прилог проучавању придева типа боговетан, ЈФ LXV, 2009, 299-317.

157. Boryś Wiesław, Collectiva $w$ gwarach serbsko-chorwackih, Rocznik Slawistyczny XXXIII, 1972, 33-46.

158. Boryś Wiesław, Prasłowiańskie prefiksy imienne pa-, pra-, sọ-, ọ- w języku serbskochorwackim, Rocznik Slawistyczny XXXIV, 1973, 69-81.

159. Boryś Wiesław, Inovacijske tendencije tvorbe riječi u štokavskom narječju, Hrvatski dijalektološki zbornik VII/1, 1985, 51-58.

160. Boryś Wiesław, Из дериваиије именица у изворним средњовековним српским споменицима, НССВД 14/1, 1985, 129-135.

161. Boryś Wiesław, Hybrydalneformacjesłowotwórczew dialektachserbsko-horwackich, in: Formacje hybrydalne w językach słowiańskich, Rozsprawy Slawisticzne 1, UMCS, Lublin, 1986 [1987], 125-131.

162. Бошков Дана, Придевска негаџија префиксима (не-, а-, дис-, без-), НJ XXV, 1981, 63-67. 
163. Бошковић Радосав, Нешто о употреби наставка -ар у једној групи туђих речи, HJ I, 1933, 205-209.

164. Бошковић Радосав, Поводом чланка г. А. Паунова, НJ I, 1933, 275-278. ${ }^{20}$

165. Бошковић Радосав, Развитак суфикса у јужнословенској језичкој заједници, Библиотека Јужнословенског филолога 6, Београд, 1936. Прештампано у: Радосав Бошковић, Одабрани чланци и расправе, Титоград 1978, 49-175; Радосав Бошковић, Основи упоредне граматике словенских језика (фонетика, морфологија, грађење речи), Београд, 2000, 205-348.

166. Бошковић Радосав, Значај система „суфиксалности” за стварање изведених речu, in: Saopštenja i referati 1, III međunarodni kongres slavista, Beograd, 1939, 33. Прештампано у: Радосав Бошковић, Одабрани чланции и расправе, Титоград 1978, 185.

167. Бошковић Радосав, О придевима типа ораћи, НJ I, 1950, 116-131. Прештампано у: Радосав Бошковић, Одабрани чланци и расправе, Титоград 1978, 207-218.

168. Б[ошковић] Р[адосав], Протестни, азбестни итд.; телефонисткиња, пијанисткињ $а$ итд., НJ I, 1950, 285-294. Прештампано у: Радосав Бошковић, Одабрани чланци и расправе, Титоград 1978, 219-225.

169. Б[ошковић] Р[адосав], Око суфикса -икаст (-ичаст), НJ XIV, 1964, 156-158. Прештампано у: Радосав Бошковић, Одабрани чланции и расправе, Титоград 1978, 261-263.

170. Б[ошковић] Р[адосав], Око суфикса -ица, НJ XV, 1966, 58-61. Прештампано у: Радосав Бошковић, Одабрани чланичи и расправе, Титоград 1978, 273-275.

171. Bošković Radosav, Iz onomastičke derivacije i povodom nje, Onomastica Jugoslavica VI, 1976, 187-193. Прештампано у: Радосав Бошковић, Одабрани члании и расправе, Титоград 1978, 437-444.

172. Бошковић Радосав, Нека питања именичке мочије и прасловенске деривације, ЗбМСФЛ ХІХ/2, 1976, 7-11. Прештампано у: Радосав Бошковић, Одабрани члании и расправе, Титоград 1978, 455-459.

173. Бошковић Радосав, Лужичко tkalča - Weberin, in: Зборник радова о Александру Белићу, Посебна издања САНУ CDXCVIII, Београд, 1976, 339-345. Прештампано у: Радосав Бошковић, Одабрани чланияи и расправе, Титоград 1978, 445-450; Радосав Бошковић, Основи упоредне граматике словенских језика, Београд, 2000, 375-380.

174. Бошковић Радосав, Један половично објашњен суфикс српскохрватски, $\mathrm{Hj}$ XXII/1-2, 1976, 15-17. Прештампано у: Радосав Бошковић, Одабрани чланции и расправе, Титоград 1978, 429-431; Радосав Бошковић, Основи упоредне граматике словенских језика, Београд, 2000, 370-372.

175. Bošković Radosav, Iz onomastičke derivacije i povodom nje, Onomastica Jugoslavica 6, Zagreb, 1976, 187-194. Прештампано у: Радосав Бошковић, Одабрани члании и расправе, Титоград 1978, 437-444; Радосав Бошковић, Основи упоредне граматике словенских језика, Београд, 2000, 349-356.

176. Бошковић Радосав, И добри Даничић неки пут задрема, ${ }^{21}$ Прилози за књижевност, језик, историју и фолклор XLII, Београд, 1976, 333-335. Прештампано у: Радосав Бошковић, Одабрани чланщи и расправе, Титоград 1978, 471-473; Ра-

\footnotetext{
${ }^{20} \mathrm{O}$ именицама на -иште (типа гледиште), полемички и нормативно интониран чланак (реакција на прилог А. Паунова у истом броју НЈ).

${ }^{21} \mathrm{O}$ антропонимском хипокористичном суфиксу -е (Чаје $\leftarrow$ Часлав), и презименима од таквих хипокористика (ЧајевићєЧаје).
} 
досав Бошковић, Основи упоредне граматике словенских језика, Београд, 2000, 372-374.

177. Бошковић Радосав, Србљи и Срби, ЗбМСФЛ ХХІ/1, 1978, 23-25. Прештампано y: Радосав Бошковић, Основи упоредне граматике словенских језика, Београд, 2000, 415-418.

178. Бошковић Радосав, Категорија старих српскохрватских личних хипокористика типа Andre, Andreta (Andrete) у интерпретащији Даничића и других, in: Зборник о Ђури Даничићу, Београд-Загреб, 1981: САНУ/JАЗУ, 329-339.22 Поново објављено у: Радосав Бошковић, Одабрани чланци и расправе, Титоград 1978, 475-487; Радосав Бошковић, Основи упоредне граматике словенских језика, Београд, 2000, 398-412.

179. Bošnjak Tomislava, Gramatička i semantička kolebljivost dvosložnih imenica sa sufiksom -ež, ${ }^{23}$ Rasprave IHJJ 31, 2005, 1-18.

180. Brabec Ivan, Hraste Mate, Živković Sreten, Gramatika hrvatskoga ili srpskoga jezika, ${ }^{24}$ Zagreb, 1952: Školska knjiga.

181. Брборић Вељко, О неким неискоришћеним творбеним могућностима у српском језику, НССВД 26/2, 1997, 465-468.

182. Брборић Ж. Вељко, Творба речи и правопис-писање сложених детерминативних формација са првом страном компонентом, in: Творба речи и њени ресурси у словенским језицима, Зборник радова са четрнаесте међународне научне конференције Комисије за творбу речи при Међународном комитету слависта, Београд, 2012: Филолошки факултет, 485-496.

183. Brozović Dalibor, Neki etnici u novom izdanju pravopisa, J I, 1952/1953, 54-56.

184. Brozović Dalibor, Poljska knjiga iz hrvatskosrpske tvorbe, J X/1, 1962-1963, 28-31.

185. Brozović Dalibor, $O$ sufiksu -er/-or $u$ imeničkim i pridjevskim brojevima i njihovim izvedenicama, J XXI/5, 1974, 129-136.

186. Bugarski Nataša, O semantičkim i sociolingvističkim aspektima tvorbežargonizovanih reči u srpskom jeziku, ППЈ 30-32, 1999-2001, 311-316.

187. Бугарски Наташа, Деадјективна именица као средство номинализаиије (у публицистичком стилу стандардног српског језика), ${ }^{25}$ ЗбМСФЛ XLVII/1-2, 2004, 297-404.

188. Бугарски Ранко, Један жаргонизовани суфикс: сx. -ак, ЗбМСФЛ XXXVIII/2, 1995, 157-167.

189. Бугарски Ранко, Жаргонизачија у творби речи, НССВД 26/2, 1997, 301-308.

190. Бугарски Ранко, Неки аспекти жаргонизације у нашем данашъем језику, ЈФ LVI/1-2, 2000, 157-161.

191. Bugarski Ranko, Žargon, Biblioteka XX vek, Beograd, ${ }^{2} 2006$.

192. Bugarski D. Ranko, Slivenice kao pokazatelj promena u jeziku i društvu, in: Темe jeзикословне у србистици кроз дијахронију и синхринију (зборник у част Љиљани Суботић), Нови Сад, 2016, 511-529.

193. Будимир Милан, О двојезичним сложеницама таутолошког типа, HJ IV, 1936, $165-168$.

194. Budja Jurica, Kurtović Ivana, Afiksalna tvorba glagola u dijalektnim rječnicima, Hrvatski dijalektološki zbornik 14, Zagreb, 2008.

\footnotetext{
${ }^{22}$ Научна конференција поводом стопедесетогодишњице рођења Ђуре Даничића одржана је у Београду и Загребу 1975. године, а зборник реферата објављен је тек 1981. године.

${ }^{23} \mathrm{O}$ колебању у граматичком роду, а не о творби.

${ }^{24}$ Творба речи 129-164. Исп. и каснија издања (и са атрибутим хрватскосрпски у наслову).

25 Деадјективним именицама овде се приступа искључиво са синтаксичких позиција.
} 
195. Budja Jurica, O- kao fakultativni alomorf glagolskoga prefiksa od-, Rasprave IHJJ 35, 2009, 21-34.

196. Budja Jurica, Delimitativni glagolni po- $u$ hrvatskom $i$ ostalim štokavskim jezicima, Croatica et Slavica Iadertina, Zadar, 2010, 89-119.

197. Букумирић Милета, Прилог познавағу творбе именица у говору Гораждевияа, ППЈ 20, 1984, 153-156.

198. Булатова Р. В., Замятина Г. И., Общеее и спечифическое в механизме построения акиентных систем суффиксалных имен в сербохорватском и словенском, in: Теоретические и методологические проблемы сопоставительного изучения славянских языков, Москва 1994: Наука, 179 - 197. ${ }^{26}$

199. Булахов Г[апейович] $\mathrm{M}$ [ихайло], Сербско-хорватские имена прилагательные на -аст и их эквиваленты в русском и белорусском языках, ЈФ XXX/1-2, 1973, $65-72$.

200. Buljan Gabrijela, Ima li mjesta za preobrazbu u denominalnoj tvorbi hrvatskih glagola?, SL 82, 2016, 155-190.

201. Бурић Милена, $O$ суфиксу -(н)ик, Осми лингвистички скуп „Бошковићеви дани", ЦАНУ, Подгорица 2012, 101-107.

202. Vaillant André, La depreverbation, Revue des etudes slaves 22, 1946, 5-45.

203. Vaillant André, Grammaire comparée des langues slaves, Tom IV, La formation des noms, Paris, 1974: Ëditions Klincksieck.

204. Valković Josip, Pridevi od imenice komuna, J VI, 1957, 19-20.

205. Величкова Славка, За един словообразувателен тип в български и србъски език, ${ }^{27} \mathrm{~J} \Phi \mathrm{LVI} / 1-2,2000,187-192$.

206. Вељковић Станковић Драгана, Експресивне глаголске творенице и њихова улога у анализи књижевног лика, Књ L LI/1-2, 2004, 125-140.

207. Вељковић Станковић Драгана, О критеријумима класификасије глагола субјективне очене, НССВД 35/1, 2006, 383-394.

208. Вељковић Станковић Драгана, Прагматички, стилски и тумачењски потениијали интензифицираних речи субјективне оцене, СJ XI/1-2, 2006, 341-371.

209. Вељковић Станковић Драгана, Деноминални деминутиви и аугментативи: значење и творба, НССВД 36/1, 2007, 387-403.

210. Вељковић Станковић Драгана, Семантичка и прагматичка вредност умањеница мотивисаних именицама са значењем мерних јединица, НССВД 38/1, 2009, 363-380.

211. Вељковић Станковић Д. Драгана, Когнитивни аспекти деминуције глагола у српском језику, in: Творба речи и њени ресурси у словенским језицима, Зборник радова са четрнаесте међународне научне конференције Комисије за творбу речи при Међународном комитету слависта, Београд, 2012: Филолошки факултет, 497-514.

212. Вендина Ивановна Татьяна, Oпыт разработки модели сопоставительного описания словообразовательных систем русского и сербохорватского языков, ЗбМСФЛ ХХХІІ/2, 1989, 99-107.

213. Вендина Ивановна Татьяна, Дифференциация славянских язиков по данным словообразования, Москва, 1990: Академия наук СССР, Институт русского языка.

\footnotetext{
${ }^{26}$ Упоређују се акценатски системи изведених (суфиксалних) класа именица у два сродна јужнословенска језика - српскохрватском и словеначком, на фону руског као источнословенског. Анализа је вршена на материјалу деадјективних именица са суфиксима -ота и -ост.

${ }^{27}$ Ауторка анализира творбени тип са префиксом не- којим се граде називи за лица, у бугарском и српском.
} 
214. Vince Z[latko], Drugarica direktor, gospođa profesor ili drugarica direktorica, gospođa profesorica?, J III/4, 1954-1955, 113-118.

215. Витас М. Душко, Крстев Ј. Цветана, Творбени обрасци у електронском речнику српског језика, in: Творба речи и њени ресурси у словенским језицима, Зборник радова са четрнаесте међународне научне конференције Комисије за творбу речи при Међународном комитету слависта, Београд, 2012: Филолошки факултет, 515-525.

216. Вићентић Биљана, Синтакса именица nomina agentis у руском у поређењу са српским, C XIII, 2009, 137-149.

217. Vončina Josip, Nazivi za sportaše u našem jeziku, J V/3, 1957, 82-84.

218. Wrocławska Elźbieta, Род и број у систему творбе именица у српскохрватском језику XV-XVII века, НССВД 13/1, 1984, 203-211.

219. Wrocławska Elźbieta, Творба именица страног порекла као саставни и истовремено посебни део творбе именица у српском језику, НССВД 26/2, 1997, 287-290.

220. Vrcić Mataija Sanja, Grahovac Pražić Vesna, Osobitosti ličkih nadimaka, FOC 15, 2006, 241-252.

221. Vujičić Dragomir, Hidronimi antroponimskog (patronimičkog) porijekla u lijevom slivu Drine, Onomastica Jugoslavica 10, Zagreb, 1982, 263-267.

222. Вујовић Душанка, Конкуренција суфикса -ика/-ица, ЗбМСФЛ ХL/2, 1997, 41-47.

223. Вујовић С. Душанка, Семантичка и деривациона обележја глагола отежаног кретаға, in: Граматика и лексика у словенским језицима (Зборник радова са међународног симпозијуме), Нови Сад-Београд, 2011, 349-359.

224. Вујовић С. Душанка, Префиксални творбени обрасци глагола кретаға, in: Творба речи и њени ресурси у словенским језицима, Зборник радова са четрнаесте међународне научне конференције Комисије за творбу речи при Међународном комитету слависта, Београд, 2012: Филолошки факултет, 527-534.

225. Vujović S. Dušanka, Glagoli kretanja pomoću prevoznog sredstva - leksičkosemantičke i tvorbene karakteristike ${ }^{28}$ in: ПУТЕВИМА РЕЧИ, Зборник радова у част Даринки Гортан Премк, Уредник Рајна Драгићевић, Београд, 2017: Филолошки факултет у Београду, 399-414.

226. Вујовић Душанка, Основна значења и префиксална деривација глагола ићи $и$ ходати, ЗбМСФЛ 55/2, 2012, 85-92.

227. Вукићевић Душанка, О значену именичких сложеница, ЗбМСФЛ XXXVII, 1994, 145-149.

228. Вукићевић Душанка, Именичке сложенице у савременом српском књижевном језику, ЗбМСФЛ XXXVIII/1, 1995, 127-174.

229. Вукићевић Душанка, О лексикографској дефиницији именичких сложеница у речнииима српског језика, НССВД 26/2, 1997, 365-371.

230. Vuković Jovan, Glagolske imenice na -nje $i$-će, PSKJ I/1, 1949, 40-53.

231. Vuković Jovan, Glagolske imenice na -nje $i$-će, PSKJ II/2, 1950, 149-171.

232. Вуковић Гордана, Етници женског рода у епској поезији, ЈФ LVI/1-2, 2000, 241-248.

\footnotetext{
${ }^{28}$ У основи је лексиколошка анализа одређене групе глагола. У једном делу чланка ауторка говори о деривацији глагола помоћу префикса из-, од-, за-, no-, y-, до-, npu-, пре-, про-, на-, об-. Анализирана група глагола учествује и у деривацији nomina agentis и nomina loci, помоћу суфикса -ач,-ник, -аш, -лац, -ица, -ница, али и именица са значењем животиња помоћу суфикса -ач,-ер,

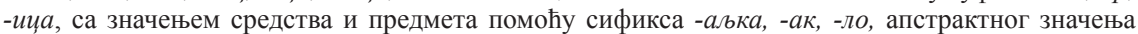
помоћу -ост, те глаголских именица на -ње.
} 
233. Вуковић Борислав, Семантичке карактеристике и однос неодређених заменица са постфиксом -нибудь и постфиксом -либо у руском и нихови еквиваленти у српскохрватском језику, ЗбМСФЛ ХХХІІ/2, 1989,121-132.

234. Вулетић Вера, Именице са суфиксом -шчина у руском и суфиксом-штина у српскохрватском, ГФФНС XV/2, 1972, 613-629.

235. Vulić Sanja, Sufiksalna tvorba imenica u gradišćanskohrvatskim kajkavskim govorima, in: Zbornik radova Riječki filološki dani 5, Filozofski fakultet, Rijeka, 2004, 585-598.

236. Vulić Sanja, Iz sufiksalne tvorbe imenica u vinišćarskom govoru, ČR 32/2, 2004, 191-201.

237. Vulić Sanja, Složeno-sufiksalna tvorba imenica u gradišćanskohrvatskim čakavskim govorima, Croatica et Slavica Iadertina I, Zadar, 2005, 47-60.

238. Vulić Sanja, Preobrazba kao rubni tvorbeni način pri tvorbi imenica u gradišćanskohrvatskim čakavskim govorima, ČR 33/1-2, 2005, 213-219.

239. Vulić Sanja, Sintaktično-semantička tvorba kao rubni tvorbeni način pri tvorbi imenica u gradišćanskohrvatskim idiomima, Croatica et Slavica Iadertina 2, Zadar, 2006, 73-82.

240. Vulić Sanja, Imeničke sraslice u gradišćanskohrvatskim govorima, ČR 34/1-2, 2006, 97-113.

241. Vulić Sanja, Čista prefiksalna tvorba imenica u gradišćanskohrvatskim idiomima, Croatica et Slavica Iadertina III, Zadar, 2007, 81-93.

242. Vulić Sanja, Prefiksalno-sufiksalna tvorba imenica u gradišćanskohrvatskim idiomi$m a$, ČR 35/1, 2007, 121-138.

243. Vulić Sanja, Čista složena tvorba imenica u gradišćanskohrvatskim idiomima, ČR 36/1-2, 2007, 97-111.

244. Вуловић Наташа/Лазић Коњик Ивана, Семантичко-деривациона анализа броја nem, Hj XXXVIII, 2007, 41-64.

245. Vučetić Zorica, Neke karakteristične sufiksalne tvorbe imenica u hrvatskom ili srpskom jeziku u odnosu na talijanski jezik, F 14, 1986, 445-452.

246. Вучковић Снежана, Конверзија као начин именичке творбе у два српска јеванђеља из ХІІІ века, НССВД 39/3, 2010, 157-173.

247. Вучковић П. Снежана, Сложенице у два српска јеванђеља из ХІІІ века-Рашкохиландарском и Мокропољском, СJ XVI/1-2, 2011, 143-159.

248. Вучковић П. Снежана, Структурно-семантичка творбена реконструкција старосрпских топонима, in: Творба речи и њени ресурси у словенским језицима, Зборник радова са четрнаесте међународне научне конференције Комисије за творбу речи при Међународном комитету слависта, Београд 2012: Филолошки факултет, 535-544.

249. Вушовић Д[анило], О пореклу и значењу речи „колач”, ${ }^{29}$ НJ II, 1934, 241-246.

250. Вушовић Д[анило], Откуда реч зеленаш?, ${ }^{30} \mathrm{HJ}, 1935,60$.

251. Газизова Ф. Раида, Семантичка функиионалност глагола у, ,микроконтекстовима", који мотивишу сложене именице ${ }^{31}$ НССВД 16/1, 1987, 131-137.

252. Георгијевић Светозар, О војвођанској ономастици , ${ }^{32}$ HJ VII, 1956, 165-177.

\footnotetext{
${ }^{29}$ Изводи је из речи коло (првобитно значење округао хлеб).

${ }^{30}$ Расправља се о значењу, само узгредно о творби.

${ }^{31}$ Ауторка је вероватно хтела рећи - „микроконтекстима”. У раду се анализирају сложенице мотивисане глаголско-именичким односима. Рад је више оријентисан ка лексикологији, мање ка творби.

${ }^{32} \mathrm{O}$ презименима насталим суфиксацијом.
} 
253. Георгијевић Светозар, О проблемима патронима, етника и ктетика у српскохрватском језику, ОП II, 1981, 123-142.

254. Georgijević Svetozar, Antroponimijski nastavak -ota, ČJOK, 269-279.

255. Görner Franz, Die Bildung der Ethnika von Ortsnamen im serbokroatischen Sprachraum, Wiesbaden, 1963: O. Harrassowitz.

256. Глибановић Вајзовић Ханка, Творба ојконима суфиксима оријенталног поријекла, in: Осма југословенска конференција и Други лингвистички скуп „Бошковићеви дани”, Подгорица, 1994, 105-114.

257. Глођовић В. Аница, Нека запажања о префиксима у српском језику, СJ XXI, 2016, 325-341.

258. Глођовић Аница, Стефановић Сандра, Један осврт на српски глаголски префикс на- и енглеску глаголску партикулу up, ЗбМСФЛ LVIII/2, 2015, 109-124.

259. Gortan Veljko, O tvorbi pridjeva od imenica na -ija, J III/4, 1955, 107-110.

260. Гортан Премк Даринка, О семантичком односу деривата према творбеној основи, НССВД 16/1, 1987, 101-107.

261. Гортан Премк Даринка, О структури и семантици деривата, HJ XXX, 19951996, 76-81.

262. Гортан Премк Даринка, Васић Вера, Недељков Љиљана, Семантичко-деривациони речник, Свеска 1: Човек - делови тела, Нови Сад, 2003: Филозофски факултет, Одсек за српски језик и лингвистику.

263. Гортан Премк Даринка, Васић Вера, Рајна Драгићевић, Семантичко-деривачиони речник, Свеска 2: Човек - унутрашни органи и ткива, психофизиолошка стаға и радње, психофизичке особине, сродство, Нови Сад, 2006: Филозофски факултет, Одсек за српски језик и лингвистику.

264. Гортан Премк С. Даринка, О наредним задацима српске дериватологије из угла једног лексикографа, in: Творба речи и њени ресурси у словенским језицима, Зборник радова са четрнаесте међународне научне конференције Комисије за творбу речи при Међународном комитету слависта, Београд, 2012: Филолошки факултет, 555-559.

265. Гочанин Мирјана, Семантичко-деривационо гнездо лексеме радити, НЈ XXXVI/1-4, 2005, 104-125.

266. Grabovac Mateja, Wortbildung im Forum teen385.com, ${ }^{33}$ in: B. Tošović, A. Wonisch (Hg./Ur.), Das Leben der Jugendlichen im Internet. Sprachliche, literarische, kulturelle und gesellschaftliche Aspekte, Neue slawistische Horizonte, Band 4, Hamburg, 2016: Dr. Kovač: 47-60.

267. Грицкат Ирена, Глагол пањкати у вези са проблемом депревербащије, JФ XVIII/14, 1949, 322-324.

268. Г[рицкат] И[рена], Како су од именице типа јунак постали придеви типа јуначки и именице типа јунаштво?, КњJ I/3, 1954, 183-184.

269. Грицкат И[рена], Деминутивни глаголи у српскохрватском језику, ЈФ XXI, 1955-1956, 45-96.

270. Грицкат Ирена, О неким видским особеностима српскохрватског глагола, ЈФ XXII/1-4, 1957-1958, 65-130.

271. Грицкат Ирена, Префиксаиија као средство граматичке (чисте) перфектизаuије, ЈФ XXVII/1-2, 1966-1967, 185-223.

\footnotetext{
${ }^{33}$ Анализирају се творбене формације: ликуша, иурићка, живчек, смајлић, створкиња, заспамавати, моб, комп, прекјут, зафештати, поглупити, сурфати, просурфати, гуглати и скинути.
} 
272. Грицкат Ирена, Шта даје за проучавање глаголске семантике чиста (граматичка) перфектизаиија путем префиксаиије?, HJ XVI, 1967, 119-126.

273. Грицкат Ирена, Robert Zett, Beiträge zur Geschichte der Nominalkompozita in Serbokroatsichen, ${ }^{34}$ Böhlau Verlag Köln - Wien, 1979, I - VI + - 368, JФ XXVIII/12, 1969, 541-548.

274. Грицкат Ирена, О именицама типа налет у српскохрватском језику, ЗбМСФЛ XXIV/1, 1981, 101-134.

275. Грицкат Ирена, Одлике глаголског видског парњаштва као семантички индикатори, ЗбМСФЛ XXVII-XXVIII, 1984-1985, 197-203.

276. Грицкат Ирена, Значења афиксалне глаголске деминуције, Први лингвистички научни скуп у спомен на Радосава Бошковића, (Даниловград 1987), ЦАНУ књ. 17, Одјељење умјетности, књ. 6, Титоград, 1988, 131-139.

277. Грицкат Ирена, О неким особеностима деминуције, ${ }^{35}$ JФ LI, 1995, 1-30.

278. Грицкат Радуловић Ирена, О дериватима на -ар $u$-ач $у$ српском језику, Глас CCCLXXXV, CAHУ, Одељење језика и књижевности, књ. 17, 1998, 31-37.

279. Грицкат Ирена, Префикс с(а)- уз глаголе у српском језику, ЗбМСФЛ XLIII, 2000, 137-141.

280. Грицкат Ирена, O суфиксу -ак и у вези с вим, CJ VIII/1-2, 2003, 23-28.

281. Грковић Милица, Имена у Дечанским хрисовуљама, Нови Сад, 1983: Филозофски факултет у Новом Саду.

282. Грковић Милица, Речник имена банског, дечанског и призренског властелинства у XIV веку, Београд, 1986: Народна књига.

283. Грковић Милица, Значај рада Вука Караџића за нашу ономастику, НССВД 17/1, 1988, 259-263.

284. Гудурић Снежана, Дробњак Драгана, „Прави” и ,лажни пријатељь” у франиуском, италијанском и српском језику, ЗбМСФЛ LIII/I, 2010, 195-204.

285. Дабић Богдан, Полусложенице у Суреповом преводу „Слова о полку Игорову”, KJ II/1-2, 1973, 73-80.

286. Дабић Богдан, Суфиксална извођења код муслиманских мушких имена, КJ VI/2, 1977, 43-50.

287. Дабић Богдан, Творбени наставак -ај у словенским језицима, КJ VI/3, 1977, 31-41.

288. Дабић Богдан, Привативни префикси не- $и$ без- у словенским језицима, КЈ XIII/4, 1984, 191-198.

289. Дабић Богдан, Творба замјенича и осталих врста ријечи од замјеничког полазишта у савременом српскохрватском језику, НССВД 16/1, 1987, 173-176.

290. Дабић Богдан, Конкурентност наставака за творбу глаголске именице у словенским језицима, JФ LVI/1-2, 2000, 321-328.

291. Dalmacija Stevo, O klasifikaciji i sufiksaciji hidronima Potkozarja, ČJOK, 55-65.

292. Dalmacija Stevo, O pridjevima kozarski $i$ kozarački, KJ XII/1, 1983, 39-41.

293. Даничић $\mathrm{\textrm {b }} / \mathrm{ypo} /$, Српска деминуција и аугментација, Гласник Друштва србске словесности ХІІ, Београд, 1860, 474-499.

294. Даничић Ђ/yро/, Основе српскога или хрватскога језика, Београд, 1876: Државна штампарија.

295. Dezső László, Синонимија у творби речи српскохрватског језика у 13-14. веку, НССВД 12/1, 1983, 5-13.

\footnotetext{
${ }^{34}$ Приказ садржи и важне критичке опсервације у вези са неким ауторовим погледима на порекло и класификацију сложеница.

${ }^{35}$ Између осталог о именичкојдеминуцији помоћу суфикса -(ч)ац, -(ч)ак, -(ч)ић, -(ч)ица, те о неким аспектима суфиксалне и префиксалне деминуције код глагола.
} 
296. Dezső László, Питањ а историјско-типолошке карактеризаиије творбе речи у старосрпскохрватском језику, НССВД 16/1, 1987, 51-58.

297. Dešić Milorad, Uticaj mjesta akcenta na tvorbu hipokoristika nastalih od ličnih imena, J X/3, 1962-1963, 86-94.

298. Дешић Милорад, Напомене о антропонимији у Книнској крајини, ${ }^{36}$ in: Осма југословенска конференција и Други лингвистички скуп „Бошковићеви дани”, Подгорица, 1994, 204-207.

299. Дешић Милорад, Акценат изведених и сложених ријечи у савременом српском језику с обзиром на акценат основне ријечи (основни типови), CJ XVIII, 2013, 23-34.

300. Dilberović Splitter Vera, Beiträge zur Bildung der Serbokroatischen Personennamen, Meisenheim am Glan, 1966: A. Hain.

301. Divković M[irko], Pridjevi na -ski, NV XVIII, 1910, 282-283.

302. Драгићевић Рајна, О српско-хрватским ономатопејским именицама с елементом -т- у суфиксу, ЈФ LIV, 1998, 121-130.

303. Драгићевић Рајна, Творбена и семантичка анализа придева који означавају ьудске особине у савременом српском језику (аутореферат о одбрањеној докторској дисертацији), КњJ XLVII/1-2, 1999, 90-95.

304. Драгићевић Рајна, Нека запажања о семантици придевских деривата у савременом српском језику, Исследования по славянским языкам 5, Корейская ассоциация славистов, Сеул, 2000, 189-196.

305. Драгићевић Рајна, Традиционално и модерно у српској лингвистици (творба речи), Лингвистичке актуелности I/3, Београд, 2000, 101-108.

306. Драгићевић Рајна, Придеви са значењем људских особина у савременом српском језику, творбена и семантичка анализа, Библиотека ЈФ, нова серија, књ. 18, Београд, 2001: ИСЈ САНУ.

307. Драгићевић Рајна, Придеви са значењем људских особина као део Дериваиионо-семантичког речника српског језика, in: Међународни научни скуп о лексикографији и лексикологији: Дескриптивна лексикографија стандардног језика и њене теоријске основе, Нови Сад-Београд, 2002, 111-117.

308. Драгићевић Рајна, Утииај мотивне речи на значење мотивисане речи у процесу дериваиије, Свет речи 15-16, Београд, 2003, 32-33.

309. Драгићевић Рајна, Творба речи и кониептуализација емоција, С 8, 2004, 120 127.

310. Драгићевић Рајна, Творба речи у настави српског језика, КњJ LII 3-4, 2005, 347-354.

311. Драгићевић Рајна, Дериваииона гнезда маркираног и немаркираног члана антонимског napa, in: Србистички прилози (Зборник у част професора Славка Вукомановића), Београд, 2005, 93-98.

312. Драгићевић Рајна, Деривати у менталном лексикону, НССВД 36/1, 2007, 367-379.

313. Драгићевић Рајна, Актуелна питаға науке о творби речи, НССВД 36/3, 2008, 61-69.

314. Драгићевић Рајна, Творбени и семантички статус једног значета именица типа ручица, СJ XIII/1-2, 2008, 203-213.

315. Драгићевић Рајна, Иновачије у творби речи у словенским језицима, 11. заседање Комисије за творбу речи Међународног славистичког комитета, Москва, 24-26. март 2009, ЈФ 65, 2009, 461-468.

316. Драгићевић Рајна, Утимај полисемије на творбу речи, КњJ LVI/1-2, 2009, 147-153.

\footnotetext{
${ }^{36}$ Узгредно и о творби антропонима (деминутивно-хипокористични типови).
} 
317. Драгићевић Рајна, Статус деривационих односа у лексикологији, С 13, 2009, 89-94.

318. Драгићевић Рајна, Словообразовательные иновации с точки зрения исследования деривационных гнезд сербского языка, in: Труды и материалы Международного научного симпозиума „Славянские языки и культуры в современном мИРе”, НОВЫЕ ЯВЛЕНИЯ В СЛАВЯНСКОМ СЛОВООБРАЗОВАНИИ: СИСТЕМА И ФУНКЦИОНИРОВАНИЕ, Москва, 2010, 148-163.

319. Драгићевић Рајна, Спонтана заједничка употреба мотивне и мотивисане речи у тексту, НССВД 40/3, 2011, 91-101.

320. Драгићевић М. Рајна, Творбено-семантичка анализа десупстантивних предлога у српском језику, in: Творба речи и њени ресурси у словенским језицима, Зборник радова са четрнаесте међународне научне конференције Комисије за творбу речи при Међународном комитету слависта, Београд, 2012: Филолошки факултет, 73-87.

321. Драгићевић М. Рајна, Просте речи и юихови деривати у тексту у српском језику, in: Słowotwórstwo słowiańskie: system i tekst, Prace Komisji Słowotwórczej przy Międzynarodowym Komitecie Slawistów, Seria 13, pod red. Jerzego Sierociuka, Poznań, 2012: PTPN, 133-141.

322. Драгићевић М. Рајна, Глаголи са два префикса у српском језику с освртом на стање у другим словенским језицима, Зборник Матице српске за славистику 83, Нови Сад, 2013, 257-268.

323. Драгићевић М. Рајна, Улога префикса у очувању или потискивању неких прасловенских глагола у савременом српском језику, СJ XIX, 2014, 235-246.

324. Драгићевић Рајна, О неологизмима у српском језику, ${ }^{37}$ in: Семинар српског језика књижевности и културе, Предавања 3, Београд, 2014: Међународни славистички центар на Филолошком факултету, 123-135.

325. Драгићевић Рајна, Различити теоријски приступи префиксащији у словенској творби речи, in: Swetlana Mengel (Hg.), Slavische Wortbildung im Vergleich, Theoretische und pragmatische Aspekte, Berlin 2014, 60-72.

326. Драгићевић Рајна, Укритање основних тенденичја у настајању неологизама y словенским језицима ( на примеру лексеме балканизација), in: osmq djsAtx, Сборник научных статей к юбилею И. С. Улуханова, Москва, 2015: Азбуковник, 236-240.

327. Драгичевич Райна, Недеминутивные значения деминутивов, in: Stramljič Breznik Irena (ured.), Manjšalnice v slovanski jezikih: oblika in vloga, Maribor, 2015, 88-101.

328. Драгићевић Рајна, Полисемија именичких деминутива, НССВД 45/3, 2016, 7585.

329. Драгићевић Рајна, Лексикализачија (на примеру именичких деминутива), in: Теме језикословне у србистици кроз дијахронију и синхринију (зборник у част Љиљани Суботић), Нови Сад, 2016, 453-463.

330. Драгићевић Рајна, Утвић Милош, Препозитивне компоненте у српском и руском језику на материјалу интернет-сајтова, in: Branko Tošović, Arno Wonisch (Hg.), Wortbildung und Internet: Institut für Slawistik der Karl-Franzens-Universität Graz, Kommission für Wortbildung beim Internationalen Slawistenkomitee, Graz, 2016, 91-106.

331. Драгићевић М. Рајна, Семантичка деривачија, ${ }^{38}$ CJ XXIII, 2018, 169-177.

\footnotetext{
${ }^{37} \mathrm{O}$ разним типовима творбених неологизама.

${ }^{38}$ Преглед различитих приступа семантичкој деривацији у славистици.
} 
332. Драгићевић М. Рајна, Негативна маркиранст придева на -ав у савременом српском језику с погледом на ситуацију у другим јужнословенским језицима, НJ XLVIII/3-4, 2018, 19-30.39

333. Драгићевић М. Рајна/Утвић М. Милош, Умножавање мовираних фемининума на -(к)иња у савременом српском језику, CJ XXIV, 2019, 187-200.

334. Дражић Јасмина, Место и улога творбе речи у минималном речнику српског језика као страног, ЗбМСФЛ L, 2007, 233-237.

335. Dugina $\mathrm{D}$ (aniel), Hrvatski purizam i tvorba riječi u raljama interneta, in: $\mathrm{B}$. Tošović, A. Wonisch (Hg./Ur.), Das Leben der Jugendlichen im Internet. Sprachliche, literarische, kulturelle und gesellschaftliche Aspekte, Neue slawistische Horizonte, Band 4, Hamburg, 2016: Dr. Kovač: 17-32.

336. Dukat Vladoje, Bjelogorica, crnogorica, HJ IV, 1936, 137-139.

337. Дурбаба Оливера, Интернет провајдери у сајбер-спејсу, Језик новог медија у (не) сагласју с къижевним језиком, ${ }^{40}$ НССВД 30/1, 2002, 189-195.

338. Дуриданов Иван, Топонимичните с̌- суфикси в южнославянските езици, Български език VIII/4-5, 343-356.

339. Ђинђић С. Марија, Семантичко-деривациони речник српског језика-модел за семантичко-деривациони речник туриизама у српском језику, in: ПУТЕВИМА РЕЧИ, Зборник радова у част Даринки Гортан Премк, Уредник Рајна Драгићевић, Београд, 2017: Филолошки факултет у Београду, 426-440.

340. Ђорђић П[етар], О двојаким завршецима неких туђииа, НJ II, 1934, 145-149.

341. Ђорђић П[етар], Именица академија и њене изведенице ${ }^{41}$ НJ II, 1934, 246-247.

342. орђић П[етар], Облик Јогословен, НJ II, 1934, 200-201.

343. Ђорђић П[етар], Ходочашће, НЈ III, 1935, 114-118.

344. Ђорђић П[етар], Из историје нашег књижевног језика, Именице типа бденије, HJ IV, 1936/4 100-107.

345. Ђорђић П[етар], Из историје нашег књижевног језика, Именице типа божанство, НJ IV/6, 1936, 169-172.

346. Ђукановић Владо, Иван Клајн, Творба речи у савременом српском језику, Први део: Слагање и префиксаиија, Београд, ЗУНС - ИСЈ САНУ, 2002, КњЈ L/1-3, 2003, 203-204.

347. Đurić Radmila, Deminutivni sufiksi u srpskom $i$ njihovi prevodni ekvivalenti $u$ engleskom, ЗбМСФЛ XLVII/1-2, 2004, 147-164.

348. Đurić Dragana, Tvorbeni procesi na forumu krstarica.com, in: B. Tošović, A. Wonisch (Hg./Ur.), Das Leben der Jugendlichen im Internet. Sprachliche, literarische, kulturelle und gesellschaftliche Aspekte, Neue slawistische Horizonte, Band 4, Hamburg, 2016: Dr. Kovač: 33-46.

349. Ђуровић Сања, Деривационо гнездо лексеме кућа-творбено-семантичка анализа, Наслеђе I/1, Крагујевац, 2004, 83-103.

350. Ђуровић Сања, О неким спорним примерима за модел комбиноване творбе у савременом српском језику, Српски језик и друштвена кретања, књ. 1, ФИЛУМ, Крагујевац, 2007, 205-214.

\footnotetext{
${ }^{39}$ На основу класификације придева на -ав у српском језику у 17 тематских група и на основу прегледа релевантне литературе о творби речи у другим јужнословенским језицима, утврђено је да највећи број придева на -ав има непожељну маркираност. Ово важи и за остале јужнословенске језике, што значи да тенденција везивања суфикса -ав за творбене основе непожељног значења већ дуго траје.

${ }^{40}$ Рад се делимично тиче импортованих сложених формација типа интернет тржиште, сајбер-рат, онлајн плаћање и сл.

${ }^{41} \mathrm{O}$ изведеницама академаи, академичар, академијин, академски.
} 
351. Ђуровић Сања, Разграничење суфикса -ик/-ник код именица које значе особу у српском књижевном језику, НССВД 36/1, 2007, 405-412.

352. Ђуровић Сања, Творбено-семантичка анализа именице врата, Наслеђе, вол. 8, бр. 20, 77-86.

353. Ђуровић Сања, Петковић Јелена, О једном типу ергонима у српском језику, ${ }^{42} \mathrm{HJ}$ XLIII/1-2, 2012, 3-14.

354. Ђуровић Ж. Сања, Творбена и семантичка анализа именица у изабраним приповеткама Иве Андрића, Наслеђе вол. 9, бр. 21, Крагујевац, 2012, 109-115.

355. Ђуровић Ж. Сања, О питањима проучавања глагола без видског парњака, ${ }^{43} \mathrm{HJ}$ XLVIII/3-4, 39-47.

356. Žepić Stanko, O tvorbi riječi, J XVII/2, 1969, 37-41.

357. Žepić Stanko, Izvedenice sa sufiksima za tvorbu mjesnih imenica (nomina loci), J XVIII/3, 1971, 83-91; XVIII/4, 105-114.

358. Жибрег Ивона, Прилог познавању глаголске деминуичје у српскохрватском језику, ППЈ 18, 1982, 79-85.

359. Живановић Јован, О српском језику, ${ }^{44}$ Нови Сад, 1888.

360. Живановић Јован, Сложене ријечи у српском језику, Глас CKA LXVIII, 1904, 175-207.

361. Živković Radoslav, O upotrebi skraćenica u dnevnim, lokalnim i fabričkim listovima, КњJ XXI/II, 1-2, 1976, 122-133.

362. Živković Slađana, Sufiksi za tvorbu imenica u engleskom jeziku i njihovi ekvivalenti u srpskom u kompjuterskom registru, Komunikacija i kultura online I/1, Beograd, 2010, 197-211.

363. Живковић Сретен, Речи на "овина" и њихова значењ $а{ }^{45}$ НJ VII/1, 1940, 8-12.

364. Жигић Татјана, Прибићевић Ивана, Из проблематике именица са месним значењем, ${ }^{46} \mathrm{HJ}$ XXVI/4-5, 1985, 253-260.

365. Жигић Татјана, Из проблематике именица с месним значењем. Питарија, НЈ XXVI, 1985, 253-256.

366. Жугић Радмила, Именичке сложенице с именицом као првим конституентом у призренско-тимочким говорима - паралела са стандардним српским језиком, Лесковачки зборник 47, Лесковац, 2007, 383-393.

367. Жугић, Радмила, Глаголски деминутиви с префиксом по- у призренско-тимочким говорима, ЗбМСФЛ, L/1-2, 2007, 257-270.

368. Жугић Радмила, Придевски деминутиви у говорима призренско-тимочке дијалекатске зоне који се односе на особине ентитета из човековог окружења (семантичко-творбени аспект), Зборник радова Филолошког факултета у Приштини 36, 2007, 377-392.

369. Жугић Радмила, Семантичка диференцијација сложених глагола с префиксом -из у стандардном српском језику, Зборник радова Филозофског факултета XXXVII, 2007, Косовска Митровица, 2008, 89-99.

370. Жугић Радмила, Сематичко-творбена анализа пејоратива за женска лица у јабланичком говору (југозападно од Лесковиа), ЗбМСФЛ LII/2, 2009, 81-106.

\footnotetext{
${ }^{42} \mathrm{O}$ именовању фирми помоћу префиксоида.

${ }^{43}$ Анализа се врши на примеру глагола важити и њихових квази видских парњака: одважити се, уважити, омаловажити.

${ }^{44}$ Збирка ауторичиних претежно полемички и пуристички обојених чланака. На много места расправља се и о творбеним питањима, највише оним која се тичу сложеница.

${ }^{45} \mathrm{O}$ извођењу именица са значењем земље, меса, дрвета, биљке, плате, производа радюе.

${ }^{46} \mathrm{O}$ именицама питарија (Татјана Жугић), винотека, жељотека (Ивана Прибићевић).
} 
371. Жугић Радмила, Пејоративи за мушка лица у јабланичком говору од нископродуктивних суфикса и юихов семантичко-творбени однос према пејоративима са продуктивним суфиксима -ко, -ља, -оња, -ча, Зборник Матице српске за славистику 78, 2010, 219-237.

372. Жугић Радмила, Лексикографски поступии тумачења семантике изведеница на основу односа творбене основе и творбеног форманта, in: Граматика и лексика у словенским језицима (Зборник радова са научног симпозијума), Нови Сад - Београд, 2011, 403-412.

373. Жугић Радмила, Именичке изведенице суфиксима -це, -е, -ле у призренско-тимочким говорима, ЗбМСФЛ 55/2, 2012, 193-202.

374. Жугић Радмила, Значај очуваности деминутивног суфикса -ка за историју српског језика, HJ XLVIII/3-4, 49-56.

375. Зонић Божидар, Суфиксаиија личних имена у Васојевићима, in: Осма југословенска конференција и Други лингвистички скуп „Бошковићеви дани”, Подгорица, 1994, 189-193.

376. Zoričić Ivan, Naglasci imenica izvedenih nultim sufiksima, Zbornik Pedagoškog fakulteta u Rijeci 4, Rijeka, 1982, 253-259.

377. Зорић С. Милена, Славенизми у Стеријиним драмским делима-именички су$\phi и к c u$, in: Теме језикословне у србистици кроз дијахронију и синхринију (зборник у част Љиљани Суботић), Нови Сад, 2016, 117-134.

378. Zoričić Ivan, Naglasak složeno-sufiksalnih imeničkih tvorenica nultim sufiksom, Radovi Pedagoškog fakulteta u Puli 4, Pula, 1983, 165-171.

379. Zoričić Ivan, Onaglaskujednosložnih izvedenica nultim sufiksom, Radovi Pedagoškog fakulteta u Puli 5, Pula, 1985, 333-338.

380. Zoričić Ivan, Naglasak imenica s dočetkom na -ovnica, J 40/1, 1992, 5-11.

381. Ивановић Ненад, Значења изведених апстрактних именица у српском језику, HJ XXXVI/1-4, 2005, 86-99.

382. Ивић Милка, André Vaillant, La depreverbation (Revue des etudes slaves 19, $p$. 5-45, Paris, 1946), JФ XVIII/1-4, 1949, 333-335.

383. Ивић Милка, Генитивне форме српскохрватских именица и одговарајућа придевска образовања суфиксом -ов (-ев, -овљев, -евљев), -ин у односу комбинаторичних варијаната, ГФФНС Х, 1967, 257-261.

384. Ивић Милка, О неким принщипима глаголске префиксащије у словенским језищима, ЈФ XXXVIII, 1982, 51-61.

385. Ivić Milka, O pridevskim obrazovanjima tipa pun puncat, in: Milka Ivić, O zelenom konju (novi lingvistički ogledi), Biblioteka XX vek, Beograd, 1995, 319-331.

386. И[вковић Милош], Бошко, ${ }^{47}$ НJ II, 1934, 134-136.

387. Ivšić Stjepan, Nešto o riječima složenima s nadri-, NV XV/7, 1907, 525-527.

388. Ivšić Stjepan, Još o riječi hodočašće, Uz članak g. P. Đorđića i „Našem jeziku” g. III, str. 114-118, HJ III, 1935, 141-143.

389. Игов А[нгел], Проблеми на сърбохърватското словосложение, Език и литература XVI/1, София, 1961, 43-48.

390. Игов А[нгел], Съединителни елементи в системата на сърбохърватското словосложение, Език и литература XVI/6, София, 1961, 31-38.

391. Илић К. Мирјана, Деривационо гнездо придева бео усрпском језику, in: ПУТЕВИМА РЕЧИ, Зборник радова у част Даринки Гортан Премк, Уредник Рајна Драгићевић, Београд, 2017: Филолошки факултет у Београду, 441-459.

\footnotetext{
${ }^{47} \mathrm{O}$ генези имена.
} 
392. Ильинский Андреевич Григорий, Сербо-хорватския прилагательныя с суффиксом -оv и русско-кашубския окончания род. п. ед. ч. м. и ср. p. -va/-vo, ${ }^{48} \mathrm{~J} Ф \mathrm{~V}$, 1925-26, 53-68.

393. Janežić Sandra, Tvorbeni procesi na forumima žena ${ }^{49}{ }^{4 n}$ : B. Tošović, A. Wonisch (Hg./Ur.), Das Leben der Jugendlichen im Internet. Sprachliche, literarische, kulturelle und gesellschaftliche Aspekte, Neue slawistische Horizonte, Band 4, Hamburg, 2016: Dr. Kovač: 67-78.

394. Јанковић М. Ђорђе, Неологизми Лазе Костића и њихова творба нултим суфиксом, CJ XXIV, 2019, 459-475.

395. Janjanin M[ilan], Gospođa profesor ${ }^{50}$ HJ II, 1934, 202-204.

396. Janjanin M[ilan], O ženskim prezimenima, HJ IV, 1936, 47-50.

397. Јармак Вероника, Рефлекси индоевропског суфикса -иско у савременом српском језику и другим словенским и несловенским језищима, НССВД 28/2, 1999, 219.

398. Јашовић Голуб, Структура и творба микротопонима и ојконима у околини Куршумлије, Зборник радова Филозофског факултета XXXVII, 2007, Косовска Митровица 2008, 79-88.

399. Jedlička Alois, Конфронтационе напомене о тзв. универбизацији и мултивербизачији, НССВД 11/2, 1982, 113-123.

400. Јелић Маријан, Нормирање етника и ктетика, ПЛ 6, 2005, 177-182.

401. Јелић Маријан, Суфикси за грађење ктетика (од ојконима у Војводини), НЈ XXXVI/1-4, 2006, 53-64.

402. Јелић Маријан, Творба етника и ктетика - од ојконима у Војводини, СЈ 12/1-2, 2007, 459-468.

403. Јелић Маријан, Етници и ктетици у Војводини, Универзитет у Новом Саду, 2010: Педагошки факултет у Сомбору.

404. Јелић Маријан, О универбизаиији у пчеларској терминологији, in: Лексикологија, ономастика, синтакса (Зборник у част Гордане Вуковић), Нови Сад, 2011, 249-256.

405. Јеремић Д. Драгољуб, Крвавити, крвављење; крварити, крварење, ${ }_{51}^{1} \mathrm{HJ}$ X, 1960 , 279-283.

406. Jerković Jovan, Povodom nekih tvorbenih novina u jeziku pisaca, Godišnjak Saveza društva za primjenjenu lingvistiku Jugoslavije 7-8, Sarajevo, 1984, 69-74.

407. Jernej Josip, Glagoli na -irati u XVII. i XVIII. stoljeću, F 2, 1959, 31-40.

408. Јешић Г. Неђо, Народни називи воћака у српском језику у свјетлости важнијих творбених типова, ${ }^{52}$ in: ПУТЕВИМА РЕЧИ, Зборник радова у част Даринки Гортан Премк, Уредник Рајна Драгићевић, Београд, 2017: Филолошки факултет у Београду, 462-473.

409. Јовановић Владан, Неки аспекти прагматичке употребе деминутивних имениuุa, HJ XXXVI/1-4, 2005, 100-103.

410. Јовановић Владан, О неким поступиима лексикографске обраде твореница, НЈ XXXIX/1-4, 2008, 43-52.

\footnotetext{
${ }^{48}$ Поред осталог и о деадјективним именицама типа гаров, шаров, рундов и сл.

${ }^{49} \mathrm{O}$ формацијама као што су: еврић, лапић, шопинговати, самосликати, грандовски, форумски.

50 Залаже се за употребу изведеница типа професорица, докторка, докторовица, учитељка, адвокатовица и сл. Чланак је пуристички интониран.

${ }^{51}$ Више о семантици, мање о творби.

${ }^{52} \mathrm{O}$ творбеним аспектима народне воћарске терминологије. Највећи број назива изведен је суфиксима -ка, -ача/-јача, -ица .
} 
412. Јовановић Владан, Деминутивне и аугментативне именице у српском језику, Београд, 2010: ИСЈ САНУ.

412. Јовановић Владан, Везане основе домаћег (словенског) порекла у морфемској и творбеној структури српског језика, ЗбМСФЛ LIX/1, 2016, $103-113$.

413. Јовановић Ж. Владимир, Проблеми одређивања сложених придева у енглеском и српском језику, ПЛ 3, Нови Сад, 2002, 102-110.

414. Јовановић Владимир, Рекурзивна префиксаиија у енглеском и српском језику, Примењена лингвистика 7, Нови Сад, 2006, 215-227.

415. Јовановић Гордана, Деривачија хришћанских имена у српским повељама и турским пописима, in: Осма југословенска конференција и Други лингвистички скуп „Бошковићеви дани”, Подгорица, 1994, 176-179.

416. Јовановић Симић Р. Јелена, Творбено-структурне и стилске особености изведенииа са формантом -ки, in: Творба речи и њени ресурси у словенским језицима, Зборник радова са четрнаесте међународне научне конференције Комисије за творбу речи при Међународном комитету слависта, Београд, 2012: Филолошки факултет, 561-572.

417. Jozić Željko, Vukša Perina, Ćurković Dijana, Nazivi za bratova sina u hrvatskome jeziku, ${ }^{53}$ Rasprave IHJJ 37/2, 2011, 393-422.

418. Jonke Ljudevit, Glagolski aspekt u tvorbi i u rečenici, J XI/3, 1964-65, 65-72.

419. Jonjić Maja, Wortbildung im Internet. Eine Analyse neuer Lexeme auf kroatischen, bosnischen und serbischen Foren ${ }^{54}$ in: B. Tošović, A. Wonisch (Hg./Ur.), Das Leben der Jugendlichen im Internet. Sprachliche, literarische, kulturelle und gesellschaftliche Aspekte, Neue slawistische Horizonte, Band 4, Hamburg, 2016: Dr. Kovač: 79-100.

420. Jovićević Radojica, Ponarođena grčka i grcizirana nomina propria $u$ Asemanovom jevanđelju, Onomastica Jugoslavica 10, Zagreb, 1982, 83-84.

421. Јошић Г. Неђо, Народни називи воћака у српском језику у свјетлости важнијих творбених модела, in: ПУТЕВИМА РЕЧИ, Зборник радова у част Даринки Гортан Премк, Уредник Рајна Драгићевић, Београд, 2017: Филолошки факултет у Београду, 461-473.

422. Јоцић Мирјана, Глаголи са суфиксима -иса, -ира, -ова у савременом српскохрватском књижевном језику, ППЈ 5, 1970, 121-175.

423. Jurin Ana, Tvorba umanjenica u hrvatskome i poljskome jeziku, Strani jezici 36/3, Zagreb, 2007, 231-244.

424. Jurišić Blaž, O produktivnim formantima u tvorbi nomina agentis, Ivšićev zbornik, Zagreb, 1963, 183-190.

425. Казимировић Бранислава, Префиксални образаи творбе српскохрватских придева и прилога, ППЈ 24-26, 1988-1990, 145-159.

426. Kakridis Yannis, Утврђивање творбених категорија: синтагматски и парадигматски приступ, НССВД 28/2, 1999, 181-187.

427. Kalogjera Damir, O jeziku i spolu, Delo XXVII/4, Beograd, 1981, 38-52.

428. Kantor Marvin, On multiple prefixation, aspect and procedurals, ЗбМСФЛ ХХІ/1, 1978, 47-54.

\footnotetext{
${ }^{53} \mathrm{O}$ изведеницама синоваи, нећак, братанаи, братић из дијалекатске, историјске и стандардолошке перспективе.

${ }^{54} \mathrm{O}$ структурама типа фејс, блогоманија, најтарантиновскији, линкан, едукати, спелати, прогуглати, загуглати.
} 
429. Kantor Marvin, The Serbo-Croatian Preverbs o- and ob-, ЗбМСФЛ XXVII-XXVIII, 1984-1985, 321-325.

430. Kapetanović Amir, Jesu li endocentrične imeničke složenice tvorbena inovacija u hrvatskom jeziku 19. stoljeća?, Rasprave IHJJ 33/1, 2007, 235-243.

431. Katunar Daniela, Diminutives in Action: A cognitive account of diminutive verbs and their suffixes in Croatian, ${ }^{55}$ SL 75, 2013, 1-23.

432. Караџић Стефановић Вук, Главна свршиваға суштествителни и прилагателни имена у српском језику, Даница, Беч, 1828, 1-135. Прештампано у: Сабрана дела Вука Караџића, књига осма, Београд, 1969, 233-321.

433. Караџић Стефановић Вук, [Творба глагола], in: О језику и књижевности II, Сабрана дела Вука Караџића, Београд, 1986, 363-431.

434. Кашић Јован, Хаиићево „Ображавање српске речи” и Вукова „Главна свршивања", НССВД 14/3, 1985, 39-46.

435. Кашић Јован, Продуктивна морфолошка средства у жаргону ${ }_{5}^{56}$ НССВД 16/1, 1987, 71-74.

436. Kirfel Kukavica Sabine, Главне ирте немачко-српског језичког контакта - са освртом на творбену структуру преведеница у касном славеносриском добу, ${ }^{57}$ НССВД 26/2, 1997, 253-262.

437. Kirfel Sabine, Интернационализачијске тенденције у српској лексици (на примерима из дневне штампе), ${ }^{58}$ НССВД 39/1, 2010, 227-238.

438. Киршова Маријана, Творба српскохрватских назива пословно-смештајних објеката са суфиксом -ница, КњJ XVII/1, 1970, 40-54.

439. Киршова Маријана, Творба назива пословно-смештајних објеката, КњЈ XVII/2, 1970, 208-221.

440. Kiršova ${ }^{59}$ Marijana, Deverbativi na -ač $i$-lac, KJ 1-2, 1972, 37-46.

441. Киршова Маријана, Нека питања методике рада на творби речи, НJ XXIV/12, 1979, 82-91.

442. Киршова Маријана, Nomina loci (месна имена) у савременом српскохрватском језику (I), ЗбМСФЛ ХХІІІ/1, 1980, 101-133.

443. Киршова Маријана, Nomina loci (месна имена) у савременом српскохрватском језику (II), ЗбМСФЛ ХХІІІ/2, 1980, 83-103.

444. Киршова Маријана, Наименования лии по этнической или государственной принадлежности в современном сербохорватском языке (в сравнении с русским), Зборник Матице српске за славистику XXXII, Нови Сад, 1987, 169-186.

445. Киршова Маријана, Аугментативи са суфиксима -ина, -етина, -урина у Вуковом речнику, НJ XXIII/1-2, 1988, 42-54.

446. Киршова Маријана, Глаголске именице са суфиксом -ње као термини у савременом књижевном српскохрватском језику, НССВД 18/1, 1990, 179-190.

447. Киршова Маријана, Прилог анализи творбено-семантичке категорије nomina instrumenti у савременом књижевном српскохрватском језику (у поређену с руским), НССВД 20, 1991, 361-373.

\footnotetext{
${ }_{55}$ У раду се расправља о деминутивним глаголима унутар теоријског оквира когнитивне лингвистике. У фокусу су деминутивни глаголи образовани суфиксацијом.

${ }^{56}$ Поред осталог и о „скраћивањима” типа маг од магнетофон, преф од преферанс и сл.

${ }^{57}$ Категоризују се начини посрбљавања немачких лексема уопште, укључујући и творбене начине (слагање, префиксацију и суфиксацију).

${ }^{58}$ Између осталог и о сложеним структурама ( „именичким полусложеницама”) типа бејзбол играч, поп сиена, е-новине, аудио опрема, и сл.

${ }^{59} \mathrm{y}$ часопису грешком стоји Keršova.
} 
448. Киршова Маријана, О неким врстама српскохрватских именичких сложеница (у књижевним текстовима и у речницима), НJ XXIX/3-4, 1993, 182-196.

449. Киршова Маријана, Називи за лице и оруђа са суфиксом -атор у српском језику у поређену са руским, ЗбМСФЛ XXXVII, 1994, 265-277.

450. Киршова Маријана, Nomina agentis у погледу стилске обојености у савременом српскохрватском језику (у поређењу са руским), НССВД 23/2, 1995, 279-289.

451. Киршова Маријана, Норма, стил и творба речи, НССВД 24/1, 1995, 169-177.

452. Киршова Маријана, Развојна динамика неких општесловенских творбених форманата у савременом српском језику (у поређењу са руским), НССВД 25/2, 1996, 427-433.

453. Киршова Маријана, Поводом питања неких творбених модела nomina agentis $y$ савременом српском и руском језику, Ријеч II/1-2, Никшић, 1996, 90-98.

454. Киршова Маријана, Најфреквентнији творбени модели у данашњој итампи, Трећи лингвистички скуп „Бошковићеви дани”, ЦАНУ, Подгорица, 1997, 109-114.

455. Киршова Маријана, Nomina agentis $u$ nomina instrumenti y српском и руском књижевном језику, Универзитет Црне Горе, Подгорица, 1998: ОДП Штампарија „Требиње”.

456. Киршова Маријана, Nomina loci у савременом српском језику, Универзитет Црне Горе, Подгорица, 1999: ОДП Штампарија „Требиње”.

457. Киш Наташа, Ајџановић Милан, О употреби именица са значењем особа, ППЈ 38, Нови Сад, 2007, 223-23.

458. Клајн Иван, О префиксоидима у српскохрватском језику, НJ XXIII/5, 1978, 187-198. Прештампано у: Иван Клајн, Лингвистичке студије, Београд, 2000: Партенон, 120-136.

459. Клајн Иван, Два правописна проблема у вези са страним речима (писање сложеница и полусложеница; неједначење по звучности), in: О лексичким позајмљеницама, Суботица-Београд, 1996: ГБС - ИСЈ САНУ, 121-127.

460. Клајн Иван, Граматички и лексикографски статус глаголских именица од несвршених глагола, НССВД 27/2, 1998, 149-157.

461. Клајн Иван, Творба речи у савременом српском језику, Први део, Слагање и префиксација (Прилози граматици српскога језика I), Београд, 2002: ЗУНС.

462. Клајн Иван, Творба речи у савременом српском језику, Други део, Суфиксација и конверзија (Прилози граматици српскога језика II), Београд, 2003: ЗУНС.

463. Кликовац Душка, О значењу српског глаголског префикса раз- (когнитивнолингвистички приступ), НJ XXXII/3-4, 1998, 153-167.

464. Кликовац Душка, О различитим врстама префиксалног значења: лексичко и творбено значење глаголског префикса раз-, in: Дескриптивна лексикографија стандардног језика и њене теоријске основе, Нови Сад - Београд, 1998: САНУ, Матица српска, ИСЈ САНУ, 185-195.

465. Кликовац Душка, $О$ значењским односима унутар творбене породице с кореном пун, НССВД 29/1, 2000, 185-196.

466. Кликовац Б. Душка, О семантищи глаголског префикса уз-, in: Творба речи и њени ресурси у словенским језицима, Зборник радова са четрнаесте међународне научне конференције Комисије за творбу речи при Међународном комитету слависта, Београд, 2012: Филолошки факултет, 573-600.

467. Ковачевић Борко, Глаголске именице на -ње у српском језику и герунд у енглеском, ЗбМСФЛ 51/1-2, 2008, 233-242.

468. Ковачевић Милош, Префиксација и њен утицај на форму и семантику синтагме, НССВД 16/1, 1987, 119-129. 
469 Ковачевић Милош, Творенице с префиксом ДЕ(3)- у српском језику, іп: Наука и образовање, Зборник радова са научног скупа (Бања Лука, 11-12. новембра 2005), Бања Лука, 2005, 153-175. Прештампано у: Милош Ковачевић, Србистичке теме, Крагујевац, 2007, 129-147.

470. Ковачевић Милош, Плеонастичка употреба префикса у српском језику, НССВД 39/1, 2010, 97-112.

471. Ковачевић Милош, Префиксалне творенице са значењем поновљивости у савременом српском језику, in: V међународни скуп „Српски језик, књижевност, уметност", 1: Књижевни (стандардни) језик и језик књижевности (ур. Милош Ковачевић), Крагујевац 2011, 19-32. Прештампано у: Милош Ковачевић, Граматичка питаға српскога језика, Београд, 2011: Јасен, 81-101.

472. Kolarič R/udolf/, Imenice na -ci $i$-ovci $v$ Vojvodini, ЗбМСФЛ II, 1959, 38-141.

473. Kolenić Ljiljana, Tvorba osobnih imena u gramatici Marijana Lanosovića iz 1795, in: Осма југословенска конференција и Други лингвистички скуп „Бошковићеви дани", Подгорица, 1994, 182-188.

474. Колман О[такар], Још нешто о речима на -иште, НJ II, 1934, 13-19.

475. Коњик Лазић Ивана, Вуловић Наташа, Семантичко-деривациона анализа броја пет, ${ }^{60} \mathrm{HJ}$ XXXVIII, 2007, 43-64.

476. Коњик Лазић В. Ивана, Семантичко-деривациони потенцијал речи у откривању лексичких и културалних конотација (на примеру концепта живот), in: Творба речи и њени ресурси у словенским језицима, Зборник радова са четрнаесте међународне научне конференције Комисије за творбу речи при Међународном комитету слависта, Београд, 2012: Филолошки факултет, 609-621.

477. Копривица Верица, Супстантивизација придева мушког рода у чешком и српском језику, С 8, 2004, 369-374.

478. Копривица Верица, Именице са суфиксом -ица у атрибутској функцији и њихови чешки еквиваленти, С 13, 2009, 327-333.

479. Копривица Верица, Творба именица од придева, Београд, 2008: Филолошки факултет.

480. Копривица Д. Верица, Лексичкосемантичке групе као полазиште за конфронтациону анализу деривационих система два словенска језика, in: Творба речи и њени ресурси у словенским језицима, Зборник радова са четрнаесте међународне научне конференције Комисије за творбу речи при Међународном комитету слависта, Београд, 2012: Филолошки факултет, 601-608.

481. Коряковцева Е.И., О словообразовательной компресии в современных славянских языках: неоунивербаты - nomina abstracta, ${ }^{61}$ CJ XIX, 2014, 425-437.

482. Kosanović Marija Magdalena, Vidski parovi građeni pomoću glagolskih sufiksa u ruskom, poljskom i srpskom jeziku, ПЛ 2, Нови Сад, 2001, 55-66.

483. Костић Д[рагутин], Преудешавағе грчколатинских међународних речи на -іum (-ion), ${ }^{62} \mathrm{HJ} \mathrm{I} / 5,1933,149-154$.

484. Костић Д[рагутин], Прилог спортској терминологији, НJ II, 1934, 247-251.63

485. Костић Д[рагутин], Писање „женских презимена”, НJ III, 1935, 200-206.

486. Костић Д[рагутин], Значење глаголског префикса „," које се губи, ${ }^{64}$ HJ V, 1937, 37-40.

\footnotetext{
${ }^{60}$ Рад је заснован на претходно оформљеном семантичко-деривационом гнезду.

${ }^{61}$ Грађа садржи и српске универбе (генералка и сл.).

${ }^{62}$ Више о формалној страни неких позајмљеница, мање о творби.

${ }^{63} \mathrm{O}$ изведеници ногомет и њој сличним.

${ }^{64}$ О глаголима који су некад имали значење „заједнице”.
} 
487. Kravar Miroslav, O imenicama učenoga podrijetla na -ik ili -ičar, J II/4, 1952-1953, 102-107.

488. Kramarić Ivica, Još jednom o sucu $i$ sutkinji (Stvar ipak nije tako jednostavna), J XXXV/4, 1988, 120-125.

489. Kretschmer Anna, О норми у предвуковском књижевном језику: стране речи и модели творбе речи, НССВД 26/2, 1997, 241-252.

490. Krile Ivo, Podudarnost formalnih i značenjskih sadržaja u prefiksalnoj i sufiksalnoj tvorbi nekih glagolskih oblika, F 9, 1979, 169-175.

491. Крстић Маја, Властите именице као творбена основа у руском и српском језику (Презимена руских писаиа XIX и ХХ века као творбена основа), С XIII, 2009, $110-119 .{ }^{65}$

492. Kruszec Agata, Vukova trpeza - kulinarska terminologija u prvom izdanju „Srpskog rječnika” Vuka Stefanovića Karadžića (1818), ЗбМСФЛ XLVII/1-2, 2004, 233-296. ${ }^{66}$

493. Kuna Branko, Nazivlje u tvorbi riječi, F 46/7, 2006, 165-182.

494. Kuna Branko, Proučavanje tvorbe riječi u hrvatskom jeziku tijekom 20. stoljeća, in: Hrvatski jezik u XX. stoljeću (Zbornik radova sa znanstvenog skupa), Zagreb, 2006, 339-365.

495. Kuna Branko, Mikić Ana, Sinonim(ič)nost i uporaba glagola na -avati/-ivati, Nova Croatica III/ 3, Zagreb, 2009, 33-50.

496. Lađević Milica, Prilog proučavanju naših nadimaka, ČJOK, 319-329.

497. Лазаревић Д. Радмила, Један осврт на дериваиију хроматских придева у италијанском и српском језику, СJ XXI, 2016, 561-573.

498. Лашкова Лили, Из творбе придевских сложенииа у српскохрватском и бугарском књиюевном језику, НССВД 16/1, 1987, 139-147.

499. Lewis Kristian, Stebih Golub Barbara, Tvorba riječi i reklamni diskurs, Rasprave IHJJ 40/1, 2014, 133-147.

500. Легурска Палмира, Бечева Ничка, Проблеми на семантиката на диминутивите в руския, сръбския и българския език и представянето й в двуезичен речник, ЈФ LVI/1-2, 2000, 577-588.

501. Лепојевић Б. Јелена, Специфичности творбе двокомпонентних глагола у руском и српском језику, Радови Филозофског факултета 13/1, Источно Сарајево, 2011, 587-600.

502. Лепојевић Б. Јелена, Супстантивизачија као начин творбе и њени варијетети: пуна и контекстуална, СJ XXIII, 2018, 601-623.

503. Leskien A[ugust], Grammatik der serbo-kroatischen Sprache (Stammbildung der Nomina, 228-329; Das Verben: Stammbildung und Aktionsarten, 458-501), Heidelberg, 1914: Carl Winter's Universitätsbuchhandlung. (Друго издање, фототипски: Heidelberg, 1976, Carl Winter • Universitätsverlag.)

504. Linarić Nevenka, Robert Zett, Beiträge zur Geschichte der Nominalkomposita im Serbokroatischen, Die altserbische Periode, Bohlau Verlag, Köln - Wien 1970, I-VII +1-335, Slovo 23, Zagreb, 1973, 232-235.

${ }^{65}$ Анализирају се примери деривата изведених од презимена познатих руских писаца на грађи руског језика, а узгредно се дају творбени еквиваленти у српском језику (придеви на -ов, Пушкинов, на -ски, гогољевски; именице на -ист/a/, пушкинист/a/, на -истика, пушкинистика, -лог, пушкинолог, према руским дериватима на -вед, на -логија, пушкинологија, према руским дериватима на -ведение, на -изам, пушкинизам и сл. На крају се говори и о неким нормативним питањима везаним за називе улица по презимену, односно имену и презимену руских писаца.

${ }^{66}$ Рад садржи информације и о творбеној структури анализиране лексике. 
505. Ликоманова Искра, Неузуално словообразуване в южнославянските езици, in: Komparacja systemow i funkcjonowania wspołczesnych języków słowiańskich, 1, Słowotwórstwo/Nominacja, Opole, 2003, 276-281.

506. Ликоманова Искра, Прояви на тенденцията за езикова икономия в южнославянските езици, in: Komparacja systemow i funkcjonowania wspołczesnych języków słowiańskich, 1, Słowotwórstwo/Nominacja, Opole, 2003, 307-315.

507. Loknar Vladimir, Venozni $i$ venski?, J XXVII/5, 1980, 152-153.

508. Лома Александар, Српскохрватска географска имена на -ина, мн. -ине: преглед типова и проблеми класификаиија, ОП ХІІІ, 1997, 1-26.

509. Ломпар Весна, Замениие са префиксом и- у српском језику, НССВД 26/2, 1997, $155-163$.

510. Ломпар Весна, Неименована младунчад, Свет речи, 25/26, Београд, 2008, 72 74.

511. Lončarić Mijo, Etnik od Koprivnica, J XXI, 2, 1973, 56-57.

512. Lončarić Mijo, Prilog diskusiji o pisanju složenica i polusloženica, J XXVI, 5, 1979, $138-144$.

513. Lubaś Władisław, Svojilna pripona -ica v južnoslovanski toponomastiki, Jezik in slovstvo XI/6, 1966, 173-176.

514. Lubaś Władisław, Patronimski geografski nazivi sa formantom -ci, -ovci/-evci, -inci u srpskohrvatskom jeziku, АФФ VIII, 1968, 93-134.

515. Lukenda Marko, Prezimena hidronimijskog porijekla, ČJOK, 353-363.

516. Ljubenović Krsta, Izgovor $i$ pisanje prefiksa in-, kon-, sin- $i$ eks-/egz- $u$ našim složenicama, КњJ XXIV/2-3, 1977, 305-306.

517. Major Randall, Apstraktne imenice u srpskom jeziku stvorene od prostih prideva i sufiksa -ost, in: Problemi u prevođenju na engleski, V Simpozijum kontrastivna jezička istraživanja, Zbornik radova, Novi Sad, 1996, 62-68.

518. Major Randall, Problemi prevođenja nekih apstraktnih imenica (sufiks -stvo) sa srpskog na engleski jezik, ПЛ 2, Нови Сад, 2001, 87-93.

519. Makišova Ana, Imenički augmentativi u slovačkom i srpskom jeziku-građenje $i$ semantika, C IX, Beograd, 2005, 185-191.

520. Makišova Ana, Deminutivi u slovačkom i srpskom jeziku, in: Сусрет култура, Нови Сад: Филозофски факултет, 2006, 609-616.

521. Makišová Ana, Prefix, prefixoid a redukovaná koreňová morféma, Slovakistický zborník 1, Nový Sad, 2006, 62-69.

522. Makišova Ana, Pridevske složenice u slovačkom i srpskom jeziku, C XI, Београд 2007, 274-283.

523. Makišova Ana, Pogled na imeničke složenice kroz prizmu dva jezika, C XII, Београд, 2008, 278-285.

524. Makišova Ana, Prefiksacija prideva u slovačkom i srpskom jeziku, ПЛ 9, Нови Сад, 2008, 137-144.

525. Makišová Ana, Slovnodruhová príslušnost' substantívnych kompozit, Slovakistický zborník 4, Nový Sad, 2009, 72-79.

526. Makišova Ana, Derivati sa elementima grčkog porekla, Riječ, časopis za slavensku filologiju 16/1, Rijeka 2010, 98-108.

527. Makišová Anna, O novim leksemama u jeziku sa sufiksom -iáda/-ijada, C XIV, 2010, $160-165$.

528. Makišova Ana, Hibridna leksika u dva genetski srodna jezika, in: ПЛ 11, BeogradNovi Sad, 2010, 235-241.

529. Makišova Ana, Složenice sa afiksoidima, in: Susret kultura, Novi Sad 2010: Filozofski fakultet, 539-545. 
530. Makišová Ana, Typy kompozit $v$ slovenčine a srbčine, in: Slovo-TvorbaDynamickost' (Na počest' Kláry Buzássyovej), Bratislava 2010: Veda, vydavatel'stvo SAV, Jazykovedný ústav L’udovíta Štúra, 106-120.

531. Makišova Ana, Izražavanje negacije prefiksom ne- u slovačkom i srpskom jeziku, C XV, Beograd, 2011, 210-21

532. Makišova Ana, Sufiksi za građenje deminutivnih naziva u slovačkom jeziku i njihovi ekvivalenti u srpskom jeziku, in: Језици и културе у времену и простору I, Нови Сад 2013: Филозофски факултет, 209-214.

533. Maretić Tomislav, O narodnim imenima i prezimenima u Hrvata $i$ Srba, Rad JAZU 14, 1886, 81-146.

534. Maretić Tomislav, O narodnim imenima i prezimenima u Hrvata i Srba, Rad JAZU $15,1886,69-154$.

535. Maretić Tomislav, Gramatika i stilistika hrvatskoga ili srpskoga književnog jezika, ${ }^{67}$ Zagreb 1899: Štampa i naklada knjižare L. Hartmana.

536. Maretić Tomislav, Kako da tvorimo pridjeve prema grčkim imenicama na -ija?, NV XIV, 1905-6, 569-572.

537. Maretić Tomislav, Gramatika i stilistika hrvatskoga ili srpskoga književnog jezika, ${ }^{68}$ Zagreb ${ }^{2}$ 1931: Obnova.

538. Maretić Tomislav, Kritik ili kritičar i t.d. ${ }^{69}$ HJ II, 1934, 99-100.

539. Maretić Tomislav, Gramatika hrvatskoga ili srpskoga jezika, ${ }^{70}$ Zagreb, ${ }^{3} 1963$ : Matica hrvatska.

540. Maresić Jela, $O$ tvorbi umanjenica $u$ kajkavskom narječju, ${ }^{71}$ Rasprave IHJJ 41/1, 2015, 77-96.

541. Маринковић Небојша, Полисемантичка дисперзија и конкурениија творбених форманата код модела опште ознаке nomina agentis, НССВД 26/2, 1997, 321328.

542. Marić Ana, Rozličné názory na tvorenie slov v slovenčine a srbčine, ГФФНС, XXXIV/1, 2009, 103-113.

543. Марић Биљана, Синтаксичка дериваиија: мост између творбе речи и синтаксе (у руском језику у поређењу са српским), in: Творба речи и њени ресурси у словенским језицима, Зборник радова са четрнаесте међународне научне конференције Комисије за творбу речи при Међународном комитету слависта, Београд, 2012: Филолошки факултет, 623-635.

544. Марјановић Слободан, Ортографска норма у сложеници, НССВД 24/1, 1995, 215-223.

545. Марјановић Слободан, Структура назива привредних организаиија и юихова употреба, Ниш, 1995: Филозофски факултет.

546. Марјановић Слободан, Именице субјективне оцене у „Речнику пиротског говора" и граматичка норма, НССВД 26/2, 1997, 379-387.

547. Марјановић Слободан, Граматичка норма именииа субјективне очене у „Речнику пиротског говора", СJ II/1-2, 1997, 265-285.

548. Марјановић Слободан, Ортографска норма у полусложеницама, Трећи лингвистички скуп „Бошковићеви дани”, ЦАНУ, Подгорица, 1997, 95-107.

\footnotetext{
${ }^{67}$ Творба речи 292-390.

${ }^{68}$ Творба речи 252-358.

${ }^{69} \mathrm{У}$ полемички интонираном чланку залаже се за облике типа критик, ботаник, граматик и сл. (Супротставља се ставовима изнетим у Бошковић 1933.)

${ }^{70}$ Творба речи 299-420.

${ }^{71}$ Приказан је комплетан инвентар суфикса за творбу деминутива мушког, женског и средњег рода. Описани су и морфофонолошки процеси на граници основе и суфикса.
} 
549. Марјановић Слободан, Неки творбени аспекти у префиксащији, in: Књижевно дело Стевана Сремца - ново читање (Зборник радова са истоимене научне конференције), Ниш, 1997, 185-190.

550. Марјановић Слободан, Значај дериватолошких средстава за морфолошку класификачију, НССВД 27/2, 1998, 263-271.

551. Марјановић Слободан, Деклинабилност и индеклинабилност скраћеница у српском језику, Актуелни проблеми граматике српског језика, Зборник радова са научног скупа, Суботица-Београд, 1999, 121-132.

552. Марјановић Слободан, Скраћеничке сложенице и ортографска норма, НЈ XXXIII, 1-2, 1999, 47-55.

553. Марјановић Слободан, Деминуција у лесковачком говору, CJ VI/1-2, 2001, 331347.

554. Марјановић Слободан, O творби именииа префиксом без- на корпусу неких књижевних дела Д. Ћосића, СJ IX/1-2, 2004, 585-590.

555. Марјановић Слободан, Творбени систем. Део 1. Префиксачија, Ниш, 2004: Филозофски факултет.

556. Марјановић Слободан, $O$ творби именииа префиксом до-, Годишњак за српски језик и књижевност 22, бр. 9, 2009, 229-233.

557. Марков Борис, О наставциима -ана, -лија, -лук и -џија, НJ VIII, 5-6, 1957, 151-170.

558. Марков Борис, Именице с наставцима -че и -чић, НJ X, 7-10, 1960, 228-246.

559. Марков Борис, Именице са значењем лица женског пола у српскохрватском језику, НССВД 7, 1981, 177-188.

560. Марковић М. Александра, Обрада префикса у вишетомним речницима српског језика, HJ XLVIII/3-4, 93-105.

561. Marković Ivan, Repeticija i reduplikacija u hrvatskome, SL 64, 2007, 141-157.

562. Marković Ivan, Tri nehrvatske tvorbe: infiksacija, reduplikacija, fuzija, Rasprave IHJJ 35, 2009, 217-241.

563. Marković Ivan, Hrvatske stopljenice: novina u slengu, jeziku reklame i novina, in: Diskurs i dijalog, metode i primjene, Osijek, 2011, 223-238: Filozofski fakultet.

564. Marković Ivan, Hrvatske koordinativne složenice, Rasprave IHJJ 36/1, 2011, 71-95.

565. Марковић Св[етозар], О именицама на -ист(а) и сл., ${ }^{72}$ НJ III/1-2, 1952, $12-27$.

566. Marković Svetozar, Značenje i oblik deadjektivnih glagola složenih sa prefiksom o- ( $i$ po-), RFFS II, 1964, 53-84.

567. Marković Svetozar, Morfološka adaptacija imenica stranog porijekla sa sufiksom -ist $u$ srpskohrvatskom jeziku, KJ 3-4, 1972, 25-40.

568. Маројевић Радмило, Stjepan Babić, Tvorba riječi u hrvatskom književnom jeziku, Nacrt za gramatiku, Zagreb, Jugoslavenska akademija znanosti inumjetnosti (Djela, Razred za filologiju. knj. 62), Globus, 1986, str. [6] + 1-552, JФ XLIII, 1987, 245262. Прештампано у: Радмило Маројевић, Српски језик данас, Београд, 2000, 177-197.

569. Маројевић Радмило, Типологија посесивних придева у српскохрватском језику, ЗбМСФЛ ХХХ/2, 1987, 75-87.

570. Маројевић Радмило, Бошковићев метод творбено-семантичке реконструкције и юегов значај за компаративно-историјску дериватологију словенских језика, Први лингвистички научни скуп у спомен на Радосава Бошковића, (Даниловград 1987), ЦАНУ књ. 17, Одјељење умјетности, књ. 6, Титоград, 1988, 141-156. Прештампано у: Радмило Маројевић, Српски језик данас, Београд, 2000, 163176.

\footnotetext{
${ }^{72}$ Расправља се више о граматичким питањима него о творбеним.
} 
571. Маројевић Радмило, Руски антропоними и топоними у српскохрватском тексту (проблеми транскрипиије и творбено-граматичке адаптаџије), Славистички зборник III, Београд, 1988, 25-34.

572. Маројевић Радмило, Граматичке категорије у српском језику (из компаративно-историјске и теоријско-методолошке перспективе), НССВД 28/2, 1999, $17-26$.

573. Маројевић Радмило, Грађење речи у руском и српском језику, іп: Радмило Маројевић, Српски језик данас, Београд, 2000, 215-218.

574. Маројевић Радмило, Творба ријечи у српском језику у науции и настави, Прилози настави српског језика и књижевности I/1-2, Бања Лука, 2000, 49-55. Прештампано у: Радмило Маројевић, Српски језик данас, Београд, 2000,198-214.

575. Маројевић Радмило, Творба речи у савременом српском језику Ивана Клајна (1), CJ X/1-2, 2005, 685-779.

576. Маројевић Радмило, Творба речи у савременом српском језику Ивана Клајна (2), CJ XII /1-2, 2007, 501-602.

577. Маројевић Радмило, Творбена и морфолошка анализа у граматичком систему савременог српског језика (I), in: Наука и образовање, Зборник радова са научног скупа (Бања Лука, 11-12. новембра 2005), Бања Лука, 2005, 123-151.

578. Маројевић Радмило, Маца, именице тога типа, юихове творбене базе и паралелна образовања - етимолошке забиљешке, СЈ XIII/1-2, 2008, 85-101.

579. Маројевић Радмило, Српски језик: иноваиије у творби, новине у дериватолошком опису, НССВД 38/1, 2009, 15-26.

580. Маројевић Радмило, Творба двотематских ријечи (студија случаја: сунцокрет), Гласник 28, 2010, 25-33.

581. Маројевић Радмило, Још неке иноваиије у творби и новине у дериватолошком опису српског језика, НССВД 39/1, 2010, 83-96.

582. Маројевић Н. Радмило, Српски и словенски нулти суфикс, in: Творба речи и њени ресурси у словенским језицима, Зборник радова са четрнаесте међународне научне конференције Комисије за творбу речи при Међународном комитету слависта, Београд, 2012: Филолошки факултет, 637-652.

583. Martincová Olga, Neologizmy v pohledu západnoslovanské a jihoslovanské lexikografi, in: Komparacja systemow i funkcjonowania wspołczesnych języków słowiańskich, 1, Słowotwórstwo/Nominacja, Opole, 2003, 35-39.

584. Matešić Josip, Rückläufiges Wörterbuch des Serbokroatischen, I-IV, Wiesbaden, 1965-1967.

585. Matešić Josip, Das suffix -ana (neupers. h a $n$ e) im Südslavischen, Zeitschrift für Balkanologie 4, Wiesbaden, 1966, 78-88.

586. Matešić Josip, Tvorba frazema prema tvorbi riječi u hrvatskom jeziku, Македонски јазик XXXII-XXXIII, Скопје, 1981-82/84, 459-464.

587. Matijašević Fahra, Složena lična imena sa sufiksom -ka, Onomastica Jugoslavica 1, Ljubljana, 1969, 159-161.

588. Матијашевић Фахра, Акиенат и морфолошка структура двосложних антропонимијских хипокористика у области Ибра, ЈФ XXVII/1-2, 337-348.

589. Матијашевић Јелка, Суфикс -ка у руском језику и његови еквиваленти у српскохрватском, Зборник Филозофског факултета у Приштини VII, Приштина, 1970, 525-564.

590. Матијашевић Јелка, Неки руски творбени типови и њихови српскохрватски еквиваленти, Живи језици XII-XIII, Београд, 1970/1971, 15-23. 
591. Матијашевић Јелка, Структурно-семантичка компонента категорије рода именица које означавају млада бића - у руском и српскохрватском језику (са типолошког аспекта), ${ }^{73}$ НССВД 7, 1977, 199-211.

592. Матијашевић Јелка, О једном општесловенском типу грађења речи, Зборник Филозофског факултета у Приштини XV, Приштина, 1980, 121-142.

593. Матијашевић Јелка, Семантичка деривачија у њеном односу према морфолошкој деривацији и семантичка реконструкиија, $y$ : Контрастивна језичка истраживања, Нови Сад, 1980, 227-245.

594. Матијашевић Јелка, Nomina agentis в семасиологическом аспекте (на материале русского и сербохорватского языков, in: IX Международный съезд славистов, Резюме докладов и письменных сообщений, Киев, 1983: «Наука» Москва, 1983, 144-145.

595. Матијашевић Јелка, О природи префикса код глагола кретања у руском и српскохрватском језику, НССВД 14, 1984, 139-147.

596. Матијашевић Јелка, Метафоризачија као средство номинащије, Језик и пракса I, Приштина, 1986, 91-101.

597. Матијашевић Јелка, Из проблематике именица типа nomina agentis, JФ XLII, 1986, 115-128.

598. Матијашевић Јелка, Лексико-семантическое образование существительных в русском и сербохорватском языках, Studia philologica 1-2, Приштина, 1986, $11-26$.

599. Матијашевић Јелка, Око неких питаға у творби речи, НССВД 16/1, 1987, 109-117.

600. Матијашевић Јелка, Вуков Рјечник као извор грађе за социолингвистичка истраживања, НССВД 17/1, 1988, 123-131.

601. Матијашевић Јелка, Контрастивна проучавања Радосава Бошковића у светлу семантичке деривације, Први лингвистички научни скуп у спомен на Радосава Бошковића (Даниловград 1987), ЦАНУ књ. 17, Одјељење умјетности, књ. 6, Титоград, 1988, $165-176$.

602. Матијашевић Јелка, Модели у творби речи и развитак језика, НССВД 20/2, 1991, 335-343.

603. Матијашевић Јелка, Агентивно-творбени модели у руском и српском језику, Зборник Матице српске за славистику 44-45, Нови Сад, 1993, 151-175.

604. Матијашевић Јелка, Агентивност и номинација (аналитички агенс), НССВД 22/2, 1993, 279-287.

605. Матијашевић Јелка, Транспозииија у систему агентивних средстава руског и српског језика, ЗбМСФЛ XXXVII/1-2, 1994, 347-357.

606. Матияшевич Елка, Функционально - типологические расхождения в именном словообразовании славянских языков (на материале русского и сербского языков), VIII Международный конгресс МАПРЯЛ, Тезисы докладов, Регенсбург, 1994, 28-29.

607. Матијашевић Јелка, Пресещағье поља агентивности и поља експресије руског и српског језика на творбеном нивоу, НССУВД 23/2, 1995, 269-278.

608. Матияшевич Елка, Семантическая структура оценки у дериватов в русском и сербском языках, ЗбМСФЛ XL/1, 1997, 63-72.

609. Матијашевић Јелка, Деривациони модели као аксиолошка средства, С 2, 1998, $78-84$.

610. Матијашевић Јелка, О аксиолошким параметрима у деривацији, C III, 1999, $168-174$

\footnotetext{
${ }^{73}$ Поред осталог и о изведеницама на -e, -че, -ић, -чић, -aц, -ак, -ица, -ка, -цее и сл.
} 
611. Матијашевић Јелка, Префиксација и двовидност глагола, ЈФ LVI/1-2, 2000, 655-663.

612. Матијашевић Јелка, Дериватологија данас, C IV, 2000, 25-31.

613. Матијашевић Јелка, Деривачија и типови значења оцене, ЗбМСФЛ XLIII, 2000, 345-350.

614. Матијашевић Јелка, Из проблематике лексичко-семантичке спојивости у руском и српском језику (на примеру речи субјективне очене), C VI, 2002, 30-38.

615. Матијашевић Јелка, Контрастивно проучавағе руског и српског језика у домену дериватологије - стање и перспективе, Зборник Матице српске за славистику LXIV, 2003, 117-129.

616. Матијашевић Јелка, Творбене новине у руском и српском језику с почетка 20. и почетка 21. века - соииолингвистички аспект, С 8, 2004, 103-113.

617. Матијашевић Јелка, Етнокултурне особености у грађењу речи руског и српског језика, in: Сусрет култура, Филозофски факултет, Нови Сад, 2006, 561-570.

618. Матијашевић Јелка, Конвергентные явления в области словообразования русского и сербского языков, ГФФНС 31, 2006, 241-250.

619. Матијашевић Јелка, Реч са творбеног аспекта, ГФФНС 32, 2007, 387-396.

620. Матијашевић Јелка, Интерфикси у руској и српској творбеној терминологији, ЗбМСФЛ L, 2007, 489-503.

621. Матијашевић Јелка, Афиксоиди и морфемизација, Међународни симпозијум о лексикографији и лексикологији, Нови Сад - Београд, 2007, 163-173.

622. Матијашевић Јелка, Интерфикси у руској и српској творбеној терминологији, ЗбМСФЛ L, 2007, 489-503.

623. Матијашевић Јелка, Циркумфикс као творбени формант, ${ }^{74} \mathrm{C}$ 13, 2009, 316-326.

624. Матијашевић И. Јелка, Типови међујезичких еквивалената (на материјалу руских и српских именичких деминутива), in: Творба речи и њени ресурси у словенским језицима, Зборник радова са четрнаесте међународне научне конференције Комисије за творбу речи при Међународном комитету слависта, Београд, 2012: Филолошки факултет, 653-661.

625. Матијашевић Јелка, Дериватолошко-лексиколошка истраживаға руског и српског језика, ${ }^{75}$ Нови Сад, 2019: Филозофски факултет.

626. Матић С[ветозар], Сложениие са велико-, HJ IV, 9-10, 1953, 323-328.

627. Maciej Kowalonek, Упоредна анализа семантичко-деривационог гнезда лексеме рука (ręnka) у Српском рјечнику Вука Стефановића Караиића и Речнику пољског језика Самуела Богумила Линдеа, НССВД 40/1, 2011, 461-479.

628. Meillet André et Vaillant André, Grammaire de la langue serbo-croate, Paris, 1952.

629. Menac Antica, $O$ čuvanju ili ispadanju pridjevskog sufiksa -n- pri tvorbi glagola, J III/1, 1954-1955, 22-23.

630. Menac Mira, O učeničkim nadimcima, ČJOK, 377-387.

631. Mikić Čolić Ana, Tvorba glagolskih neologizama i uklapanje u jezični sustav, Fluminensia 27/1, 2015, 87-103.

632. Miklosich Franz, Die Bildung der slavischen Personennamen, Wien, 1860.

633. Miklosich Franz, Die Bildung der Ortsnamen aus Personennamen im Slavischen, Wien, 1864.

\footnotetext{
${ }^{74}$ Ауторка, на бази руске литературе, говори о појму циркумфикса и циркумфиксације, као феномена за које се у србистици, и не само у њој, користи термин префиксално-суфиксална творба.

${ }^{75}$ Зборник раније објављених радова.
} 
634. Miklosich Franz, Die Bildung der slavischen Personen- und Ortsnamen, Heidelberg, 1927.

635. Милановић Александар, О неким стилистички маркираним творбеним моделима у делу Стевана Сремиа, in: Књижевно дело Стевана Сремца-ново читање (Зборник радова са истоимене научне конференције), Ниш, 1997, 161-175.

636. Милановић Александар, Семантичка и творбена конкуренција у посрбицама предвуковског периода, Пети лингвистички скуп „Бошковићеви дани”, Подгорица, 2003, 309- 317. Прештампано у: Александар Милановић, Језик весма полезан, Београд 2013: ДСЈК, 227-234.

637. Милановић Александар, Дериватолошке карактеристике индивидуалних неологизама у Словару Ђорђа Марковића Кодера, НССВД 40/1, 2011, 351-361. Прештампано у: Александар Милановић, Језик весма полезан, Београд 2013: ДСЈК, 170-179.

638. Милановић М. Александар, Стилски аспекти творбе тзв. императивних сложеница у српској романтичарској поезији, in: Творба речи и њени ресурси у словенским језицима, Зборник радова са четрнаесте међународне научне конференције Комисије за творбу речи при Међународном комитету слависта, Београд, 2012: Филолошки факултет, 663-674. Прештампано у: Александар Милановић, Језик весма полезан, Београд 2013: ДСЈК, 159-169.

639. Милановић М. Александар, Бећковићев поетски опус као ресурс за истраживање сложеница са инфиксом -и- ${ }^{76}$ НССВД 41/3, 2012, 193-209.

640. Милановић М. Александар, Творба речи у језичком саветнику није-него Д. Косmuћa (1931), CJ XIX, 2014, 219-233.

641. Милановић М. Александар, Творба речи у Србској грамматици (1847) Јована Суботића, ${ }^{77}$ CJ XXII, 2017, 361-374.

642. Милановић Б[ранислав], Облик зависних падежа деминутивних именища на це ${ }^{78} \mathrm{HJ}$ III/7-8, 1952, 242-258.

643. Милановић Б[ранислав], Двојаки облици глагола на -ивати, -авати, ${ }^{79} \mathrm{HJ} \mathrm{V} / 7-8$, 1954, 235-249.

644. Милановић Б[ранислав], Глаголи на -нити с облицима промене -ну/-не основа, HJ VII/3-4, 1955/56, 87-106.

645. Милановић Б[ранислав], О посесивним придевима на -овљев/-евљев, НJ XI/3-4, 1961, 81-89.

646. Милашин Горан, О језику Твитера са дериватолошког становишта, in: Branko Tošović, Arno Wonisch (Hg.), Wortbildung und Internet: Institut für Slawistik der Karl-Franzens-Universität Graz, Kommission für Wortbildung beim Internationalen Slawistenkomitee, Graz, 2016, 225-254.

647. Миленковић Тијана, Творбени поступции скраћивања у српском интернету, in: Branko Tošović, Arno Wonisch (Hg.), Wortbildung und Internet: Institut für

\footnotetext{
${ }^{76}$ Указује се на висок степен продуктивности сложеница са интерфиксом - $u$ - у песничком функционалном стилу.

${ }^{77}$ Анализира се поглавље о творби речи у рукопису једне од најстаријиг српских граматика.

${ }^{78}$ На богатом материјалу анализирају се именице на -ие са позиција њихове двојаке промене (звоние - звониа, звоние - звониета).

${ }^{79} \mathrm{O}$ дублетним формама „учестало-трајних глагола који су изведени наставцима -ива- и ава- од сложених свршених глагола” типа допуњавати:допуњивати, приближавати:приближивати и сл. Закључак је да се „наставак -ава- стално шири на рачун наставка -ива-. Чланак је нормативистички интониран.
} 
Slawistik der Karl-Franzens-Universität Graz, Kommission für Wortbildung beim Internationalen Slawistenkomitee, Graz, 2016, 255-276.

648. Милојевић Ж. Вој., Један предлог за неколико назива, НJ II, 1934, 209-210.

649. Милојевић Јелисавета, Именичке сложенице са глаголском компонентом у срискохрватском језику, ЈФ XLVIII, 1992, 35-66.

650. Милојевић Јелисавета, Значењски обрасии српскохрватских именичких сложении а са глаголском компонентом, НССВД 22/2, 1993, 273-278.

651. Milojević Jelisaveta, Gramatika reči: algoritamsko opisivanje jezika na primeru složenica, Beograd, 1996: SANU, Matematički institut, Filološki fakultet.

652. Милојевић Јелисавета, Творбени модели и творбени дублети на примерима српских сложеница, НССВД 26/2, 1997, 291-301.

653. Милошевић Слађана, Две нове речи: спонзоруша $u$ пиштољаш, JД V/14, 2001, 23.

654. Minović Milivoje, O osnovima savremenih srpskohrvatskih pravopisnih normi u vezi s pisanjem složenica, Radovi III, Institut za jezik i književnost u Sarajevu, Odjeljenje za jezik, Sarajevo, 1976, 221-234.

655. Minović Milivoje, $O$ leksičko-semantičkom mikrosistemu tipa aktivnost/aktivitet $u$ savremenom srpskohrvatskom književnom jeziku (u poređenju s ruskim, poljskim $i$ makedonskim jezikom), tvorbeni aspekt, KJ 11/3, 1981, 3-18.

656. Minović Milivoje, Internacionalne tendencije u razvoju savremenog srpskohrvatskog književnog jezika, ${ }^{80} \mathrm{KJ}$ 12/1, 1983, 19-34.

657. Миовски Мито, Роберт Цет, Прилози кон историјата на именските сложенки во српскохрватскиот јазик (Robert Zett, Beiträge zur Geschichte der Nominalkomposita im Serbokroatischen, Die alterbische Periode, Bohlau, KolnWien, 1970, I-VII + 1-368), Македонски јазик XXV, 1974, 318-320.

658. Mitrinović Vera, On an apparent correspondence: adjectives of the type przepiękny, przrsławny in Polish and their counerparts in Serbo-Croatian, w: Problemy opisu gramatycznego języków słowiańskich, red. M. Grochowski, Warszawa, 1991, 119125. Прештампано у: Vera Mitrinović, Poludnie - Pótnoc (Serbsko-polskie parelele jezzykowe), Poznań, 2012: Uniwersytet im. Adama Mickiewicza w Poznaniu, 17-26.

659. Mitrinović Vera, Polski prefiks prze- a serbskie/chorwackie pre- $i$ pro- (Próba konfrontacji), Studia z Folologii Polskiej o Słowiańskiej 29, 1991, 133-143. Прештампану у: Vera Mitrinović, Poludnie - Pótnoc (Serbsko-polskie parelele językowe), Poznań, 2012: Uniwersytet im. Adama Mickiewicza w Poznaniu, 27-40.

660. Митриновић Вера, Пољски глаголски префикс prze- и юегови српскохрватски еквиваленти пре- $и$ про-, Београд, 1990.

661. Mitrićević Štepanek Katarina, Deminutivi u funkciji nabrajanja i konfrontacije u češkom i srpskom jeziku, Opera Slavica XVII, 2007, 4, 18-28.

662. Mitrićević Štepanek Katarina, Pozitivna subjektivna ocena u okviru ekspresivnog deminutivnog značenja u češkom i srpskom jeziku, C XI, 2007, 303-319.

663. Mitrićević Štepanek Katarina, Deminutivi sa pejorativnim značenjem u češkom i srpskom jkeziku, C 14, 2010, 247-259.

664. Mitrićević Štepanek Katarina, Konfrontativno proučavanje češkog i srpskog jezika na primeru deminutiva izvedenih sekundarnim sufiksima, C 16, 2012, 531-542 .

665. Митрићевић Штепанек Катарина, Деминутиви као средства интензификаиије у чешком језику и юихови еквиваленти у српском језику, C XVII, 2013, 336346.

666. Мићић М. Вишња, Како настају сложенице - методички аспект, KJ LXIII 1-2, 2016, 113-130.

\footnotetext{
${ }^{80}$ Између осталог и о творбеним формантима -инг, -ент, -ант, -изација, -итет.
} 
667. Мићовић В. М., Још о речима изведеним од именище магнет, HJ IV/1-2, 1952, 33-37.

668. Мићовић Драгутин, O српскохрватским и албанским именицама на -ар (поводом облика Косовар), НJ XXII/3, 1976, 155-157.

669. Mihajlović Velimir, Sufiks -ište u toponimiji Jugoslavije, ППЈ 1, 1965, 117-155.

670. Михајловић Велимир, Посрбище од Орфелина до Вука, I (Б - О), Нови Сад, 1982: Матица српска.

671. Михајловић Велимир, Посрбице од Орфелина до Вука, ІІ (П - Ш), Нови Сад, 1984: Матица српска.

672. Михајловић Велимир, Име по заповести: императивни ономастикон српскохрватског језика, Београд, 1992: Нолит.

673. Михајловић Јасмина, Термин видео, ${ }^{81} \mathrm{Hj}$ XXVI/4-5, 1985, 241-252.

674. Михајловић Младен, Контрастивна анализа извођењ $а$ nomina agentis у енглеском и српскохрватском језику, НССВД 16/3, 1987, 171-177.

675. Mihaljević Milica, Odnos imenica na -itet $i$ odgovarajućih imenica na -ost, J XXXII/5, 1985, 140-145.

676. Mihaljević Milica, Ramadanović Ermina, Razradba tvorbenih načina u nazivlju (s posebnim obzirom na odnos među složenicama bez spojnika -o-, sraslicama $i$ tvorenicama s prefiksoidima), Rasprave IHJJ 32/1, 2006.

677. Mihaljević Milica, Štebih Golub Barbara, Mocijska tvorba u hrvatskome i srpskome jeziku, in: Branko Tošović (Hg.), Die Unterschiede zwischen dem Bosnischen/Bosniakischen, Kroatischen und Serbischen (Grammatik), Slawische Sprachkorrelationen 3, Wien/Berlin/Münster, 2010, 81-101.

678. Modestin J[osip], Hrvatski nepravilno izvedena imena žitelja, naroda, pristaša nečijih i državina, NV XIII, 1904-5, 35-40.

679. Моловић Ј[ордан], Ораховчанин и Ораховичанин, ораховачки и ораховички, НЈ XXIII/1-2, 1977, 69-71.

680. Москов Моско, Особена общославянска префиксна система и нейното отражение в сърбохърватски език, ЗбМСФЛ VIII, 1965, 67-73.

681. Московљевић М[илош], Глаголи на -ети, -им $и$-ити, -им, НJ I, 1933, $18-21$.

682. Московљевић М[илош], Лекар и лечник, НJ I, 1933, 171-173.

683. Московљевић М[илош], „, Опкладионица” и тим поводом о именицама на -ионица, -аоница, НJ II, 1934, ${ }^{82}$ 76-77.

684. Московљевић М[илош], Мешање предметка пре- $u$ при- код неких речи, НJ II, 1934, 136-140.

685. Московљевић М[илош], Бања, купалиште, купељ, купатило, купка, ${ }^{83}$ НJ II, 1934, 234-237.

686. Московљевић М[илош], Из живота речи, ${ }^{84}$ НJ II, 1934, 268-271.

687. Московљевић С. Милош, Називи за воћњаке (Још један прилог пољопривредној терминологији), ${ }^{85} \mathrm{HJ}$ IV, 1936, 197-202.

688. Московљевић С. Милош, О грађењу неких придева на -ски од географских имена, HJ VII, 1940, 205-209.

\footnotetext{
${ }^{81} \mathrm{O}$ сложеним структурама са детерминативним препозиционалним конституентом видео-.

${ }^{82}$ Овај дериват сматра неправилним јер је сачињен од свршеног глагола, а именице на -оница се граде од несвршених.

${ }^{83}$ Расправља и о творбеним и о лексичким специфичностима наведених именица.

${ }^{84}$ Поред осталог и о аналогији у творби (трамвајиија према бозащија), о губљењу мотивације у речи стеница (од старог значења речи стена) и сл.

${ }^{85} \mathrm{O}$ изведеницама мотивисаним називима биљака, односно воћака. Прилог је нормативистички усмерен.
} 
689. Мразовић Павица, Вукадиновић Зора, Граматика српскохрватског језика за странще, Нови Сад, 1990.

690. Mrazović Pavica, ${ }^{86}$ Gramatika srpskoz jezika za strance, Sremski Karlovci-Novi Sad, 22009: Izdavačka knjižarnica Zorana Stojanovića.

691. Mulić Malik, O naglasku imenica koje se tvore pomoću sufiksa/-ъba/-ba, KJ VIII/2, 1979.

692. Mujadžić Šeherzada, Tvorba riječi na internetu (derivacioni polilog), in: B. Tošović, A. Wonisch (Hg./Ur.), Das Leben der Jugendlichen im Internet. Sprachliche, literarische, kulturelle und gesellschaftliche Aspekte, Neue slawistische Horizonte, Band 4, Hamburg, 2016: Dr. Kovač: 155-166.

693. Muljaku Ljatif, Južnoslovenski sufiksi -ica, -ina, -ište $u$ severnim albanskim govorima, in: Црногорски говори (резултати досадашњих истраживања и даљи рад на њиховом проучавању), Титоград, 1984: ЦАНУ, 173-178.

694. Muljačić Žarko, Naši pejorativi romanskog podrijetla, Radovi 3, Filozofski fakultet, Zadar, 1962, 115-138.

695. Muljačić Žarko, Tipologija jezičnoga kalka, Radovi 7, Filozofski fakultet, Zadar, $1968,5-19$.

696. Neweklowsky Gerhard, O дистинктивним обележјима суфикса у српскохрватском и другим јужнословенским језицима, НССВД 16/1, 1987, 167-171.

697. Недељков Љиљана, Шкорић Катица, Прилог проучавању српскохрватских сложенииа, ЗбМСФЛ ХL/2, 1997, 193-200.

698. Недељковић Б. Даница, Префксоиди као одлика разговорнг функиионалног стила на примеру романа Tschick Волфганга Херндорфа и његов превод на српски језик, CJ XXIII, 2018, 409-428.

699. Ненезић Соња, Придјевске сложениие са квантитативним детерминатором, Ријеч VI/1-2, Никшић, 2000, 120-128.

700. Ненезић Соња, О једном типу придјевских сложеница у српском језику, CJ V/12, 2000, 813-817.

701. Ненезић Соња, Придјевске сложенице са квалификативним детерминатором, CJ VI/1-2, 2001, 443-460.

702. Ненезић Соња, Придјевске сложенице са глаголским управним чланом, Ријеч VIII/1-2, Никшић, 2002, 117-131.

703. Ненезић Соња, Ендоцентричне придјевске сложенице у српском језику, СЈ VII/1-2, 2002, 361-372.

704. Ненезић Соња, О неким питањима творбене структуре сложеница, in: Живот и дјело академика Михаила Стевановића (радови са научног скупа, Подгорица, 16. и 17. мај 2002), ЦАНУ, Подгорица, 2002, 195-207.

705. Ненезић Соња, Дублетизам придјева на -ји и -ији у српском језику, Пети лингвистички скуп „Бошковићеви дани”, ЦАНУ, Подгорица, 2003, 237-251.

706. Ненезић Соња, О једном типу глаголских именица у свијетлу Вуковићевих истраживања, Живот и дјело академика Јована Вуковића (Зборник радова са научног скупа, Плужине, 8-9. новембра 2003), Подгорица, 2004, 176-186.

707. Ненезић Соња, Још једном о ендоцентричним придјевским сложеницама, Ријеч X/1-2, Никшић, 2004, 174-186.

708. Ненезић Соња, О једној малобројној групи сложеница, СJ IX/1-2, 2004, 397-404.

\footnotetext{
${ }^{86}$ На корицама пише да је ауторка Павица Мразовић, а на насловној страни стоји Павица Мразовић у сарадњи са Зором Вукадиновић. Творба речи није представљена скупно, у једном одељку, већ у оквиру појединих врста речи: творба глагола 92-109, творба именица 240-257, творба придева 306-312, творба прилога 459-461.
} 
709. Ненезић Соња, О једном типу детерминативних сложеница у Вуковом Српском рјечнику, in: На извору Вукова језика (III научни скуп, 2000), Жабљак, 2005, 72-83.

710. Ненезић Соња, Активизација и конкурентност неких моционих суфикса у језику ирногорских медија, Језичка ситуација у Црној Гори - норма и стандардизација (радови са међународног научног скупа, Подгорица, 24-25. мај 2007), ЦАНУ, Подгорица, 2008, 377-386.

711. Ненезић Соња, О творбено-семантичкој структури именичких пејоратива у ирногорским говорима, Седми лингвистички скуп „Бошковићеви дани”, ЦАНУ, Подгорица, 2008, 379-393.

712. Ненезић Соња, Творбени потениијал повратне замјенице себе, СJ XX, 2015, 525-535.

713. Nenezić Sonja, Deminutivni pridjevi u Rečniku srpskohrvatskog književnog jezika I-VI, in: Stramljič Breznik Irena (ured.), Manjšalnice v slovanski jezikih: oblika in vloga, Maribor, 2015, 248-256.

714. Nenezić Sonja, Vlastita imena kao motivatori nekih novo-tvorenica u jeziku crnogorskih online medija, in: Branko Tošović, Arno Wonisch (Hg.), Wortbildung und Internet: Institut für Slawistik der Karl-Franzens-Universität Graz, Kommission für Wortbildung beim Internationalen Slawistenkomitee, Graz, 2016, 289-300.

715. Nehring Dieter, Nazivi sa sufiksima apstraktnih imenica u novinama iz Sarajeva $i$ Beča posle 1878. godine, НССВД 25/2, 1996, 199-215.

716. Nehring Dieter-Gerd, Српски сложени придеви у поређењу са суседним језицима, НССВД 35/1, 2006, 339-352.

717. Нещименко Парфеньевна Галина, Гайдукова Юрьевна Юлия, $K$ проблеме сопоставительного изучения славянского именного словообразования, $y$ : Теоритечиские и методологические проблемы сопоставительного изучения славянских языков, Москва, 1994: Наука, 93-126.

718. Нещименко П/арфеньевна/ Г/алина/, Парные феминативы как объект словообразоватльной конкуренции, ${ }^{87}$ CJ XIX, 2014, 59-84.

719. Николић Берислав, Дужина суфиксовог вокала код присвојних придева на -ин $и$ -ов (-ев) у Вука и у данашъем триићком говору, Ковчежић III, Београд, 1960, $183-185$.

720. Николић Берислав М., Акиенат изведених именица у српскохрватском језику, ${ }^{88}$ HJ XII, 1962, 270-279.

721. Николић Берислав М., Акценат изведених именица у српскохрватском језику, ${ }^{89}$ HJ XIII, 1963, 95-114.

722. Николић Берислав, Акиенат интернационализама у савремном српскохрватском књижевном језику, ${ }^{90}$ HJ XVIII/4-5, 1971, 220-228.

723. Николић Берислав, О глаголском виду с творбене стране, КњЈ XIX/4, 1972, 26-30.

\footnotetext{
${ }^{87}$ Са посебним одељком о парним феминативима у српском (српскохрватском) језику.

${ }^{88}$ Акценат изведеница на: -ба, -ава, -иво, -уг, -уга, -ад, -да, -еж, -ај, -оје, -yj, -ак, -ака, -ика,

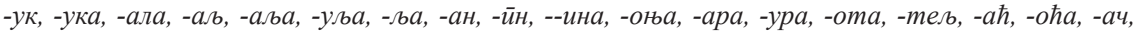
- иима, -уша, -о/-а.

${ }^{89}$ Акценат изведеница на: -ьје, $-\bar{a} \kappa,-(a) \kappa,-\bar{u} \kappa,-\kappa a,-л о, ~-\bar{a} н,-и н,-и н а,-и њ a,-њ a,-\bar{a} p,-е p,-о c m$, -ство, -ић, -йћ, -ица-аи, -иее, -ача, -аш, -ош, -иште.

${ }^{90} \mathrm{O}$ акценту именица на -унг, -ург, -ада, -ијада, -ажа, -иза, -оза, -ик, -ика, -ал, -ол, -изам, -ан,

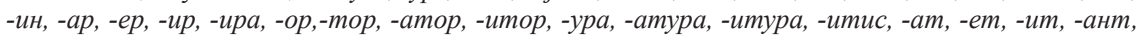
-ент, -еут.
} 
724. Николић Берислав, Основни принципи творбе речи у савременом српскохрватском киижевном језику, НJ XIX/1, 1972, 7-20; 2-3, 1972, 142-154; 4-5, 1973, 273-286.

725. Николић Берислав, Основни деривациони принципи у савременом српскохрватском књижевном језику, Прилози за књижевност, језик, историју и фолклор XXXIX/3-4, Београд, 1973, 215-225.

726. Николић С. Весна, Вукови погледи на творбу придева, CJ XXIV, 2019, 609-623.

727. Николић Душан, Писање сложених скраћеница, НJ XXVI/4-5, 1985, 264-268.

728. Николић Мирослав, Поводом двојаког облика једне изведенище, Књ $\mathrm{XXI} / 1$, 1974, 121-124.

729. Николић Мирослав, О изведеницама типа усисивач, НJ XXIII/1-2, 1977, 30-36.

730. Николић Мирослав, О хипокористицима типа Чале - Чала - Чалов, Први лингвистички научни скуп у спомен на Радосава Бошковића, (Даниловград 1987), ЦАНУ књ. 17, Одјељење умјетности, књ. 6, Титоград, 1988, 259-265.

731. Николић Мирослав, Један експанзивни тип нових именичких сложеница, ${ }^{91} \mathrm{HJ}$ XXX/1-5, 1995-1996, 82-87.

732. Николић Мирослав, Непроменљиви придеви у српском језику, НJ XXXI/1-5, 1996, 35-54.

733. Николић Мирослав, Срби и Србијании, ЈД 5, 1998, 13-15.

734. Николић Мирослав, О речима изведеним од имена одн. презимена познатих личности, НJ XXXIII/1-2, 1999, 24-35.

735. Николић Мирослав, Обратни речник српскога језика, Београд, 2000: Матица српска, ИСЈ САНУ, Палчић.

736. Николић Мирослав, Иван Клајн: Творба речи у савременом српском језику, Први део: слагағе и префиксаиија, НJ XXXIV/1-2, 2001, 157-167.

737. Николић Св[етозар], О грађеґу сложених скраћеница у нашем савременом књижевном језику, ${ }^{92} \mathrm{HJ} \mathrm{V} / 1-2,1954,9-17$.

738. Николић Св[етозар], Облици имена: звања, занимања, дужности и титула женских лица, НJ VI/5-6, 1955, 148-152.

739. Ničota N. Stevan, Odbrana savremenog srpskohrvatskog književnog jezika, I, Beograd, 1957. ${ }^{93}$

740. Ničota N. Stevan, Odbrana savremenog srpskohrvatskog književnog jezika, II, Beo$\operatorname{grad}, 1958 .{ }^{94}$

741. Новаковић Новак, Родбински и својбински називи, НJ IV, 1936, $24-27$.

742. Nosić Milan, Tvorba andronima, patronima i metronima u zapadnoj Hercegovini, in: Осма југословенска конференција и Други лингвистички скуп „Бошковићеви дани”, ЦАНУ, Подгорица, 1994, 195-201.

743. Новаков С. Драгана, О суфиксима -аш, -ица, -ота, -ош, -ул у дечанском помени$\kappa y$, CJ XIX, 2014, 693-700.

744. Новаковић Стојан, Српска граматика, Београд, ${ }^{1} 1894$ : Државна штампарија.

745. Новаковић Стојан, Српска граматика, ${ }^{95}$ Београд, ${ }^{2} 1902$, : Државна штампарија.

\footnotetext{
${ }^{91}$ Између осталог и о изведеним придевима на -ли (типа бадемли, јоргованли, бисерли и сл.).

92 Дели скраћенице у три типа: гласовни тип (Нин = Недељне информативне новине), слоговни тип $($ Нама $=$ народни магазин $)$, мешовити тип $($ Танјуг = Телеграфска агенција нове Југославије, Југометал = Југословенски метал) и сл.

${ }^{93}$ Говори о творби придева.

${ }^{94}$ Пише о творби етника.

${ }^{95}$ Садржај творбе речи смештен је у одељак Наука о основама, 59-143.
} 
746. Nyomárkay István, Поређење несродних језика са гледишта грађења речи (могућност превођења српскохрватских речи с наставком -иште на мађарски), НССВД 6/1, 1977, 461-467.

747. Nyomárkay István, Улога творбе речи у покрету за обнову језика код Хрвата у другој половини ХІХ века, НССВД 16/1, 1987, 35-42.

748. Okuka Miloš, Pridjevi tvoreni od prezimena na -ski $u$ standardnom srpskohrvatskom jeziku, KJ X/1, 1981, 7-12.

749. Okuka Miloš, Die Internationalisierung des Serbischen, ${ }^{96}$ Die Welt der Slaven LVI, 2011, München, 384-406.

750. Осипова А. М., Заимствованые глаголь в славянских языках: к проблеме словообразовательной и морфемной членимости, in: Теоретические и методологические проблемы сопоставительного изучения славянских языков, Москва 1994: Наука, 126-141.97

751. Остојић Бранислав, О именичким дериватима на -/н/ик у језику Петра I Петровића, НССВД 16/1, 1987, 27-33.

752. Остојић Б/ранислав/, Творбена структура дробњачких топонима, Исследования по славянским языкам, Сеул, 2005, 71-78.

753. Otašević Đorđe, Sikimić Biljana, Okazionalizmi sa tvorbenog aspekta, Uporabno jezikoslovje, Ljubljana, 1989, 218-223.

754. Оташевић Ђорђе, Сикимић Биљана, Односи оказионализама према времену, НЈ XXIX/ 1-2, 1991, 77-81.

755. Otašević Đorđe, Sikimić Biljana, Tvorba okazionalizama u srpskohrvatskom jeziku, JФ XLVIII, 1992, 67-78.

756. Оташевић Ђорђе, Разграничење оказионализама и неологизама, НССВД 22/2, 1994, 251-255.

757. Оташевић Ђорђе, Значење придева са префиксом не-, НJ XXX/1-5, 1995-1996, $88-95$.

758. Оташевић Ђорђе, Творба придева са префиксом не-, НJ XXXI/1-5, 1996, 163-170.

759. Оташевић Ђорђе, Универбачија, Нj XXXII/1-2, 1997, 52-63.

760. Оташевић Ђорђе, Нова хибридна лексика у српском и руском језику, С II, 1998, 99-102.

761. Оташевић Ђорђе, Нове и незабележене речи, НJ XXXIII/1-2, 1999, 173-184.

762. Оташевић Ђорђе, Префикс не- са значењем искључивања, JФ LVI/3-4, 2000, 751-754.

763. Оташевић Ђорђе, Придеви и прилози с префиксом без-, НJ XXXV/1-4, 2004, $46-53$.

764. Оташевић Ђорђе, Придеви и прилози с префиксом а-, НССВД 35/1, 2006, 377-382.

765. Оташевић Ђорђе, Придеви и прилози с префиксима ин- и и-, HJ XL/1-4, 2009, 33-41.

766. Оташевић Ђорђе, Скраћенице у савременом српском језику, НССВД 40/1, 2011, 381-389.

767. Oczkowa Barbara, Nomina instrumenti we współczesnym jezyku serbochorwackim, Monografie slawistyczne 39, Wrocław, 1977.

\footnotetext{
${ }^{96}$ Велики део посвећен је интернационализацији у области творбе речи (префиксима, префиксоидима, суфиксима, суфиксоидима страног порекла).

97 У раду се говори о творбеним карактеристикама глагола типа српског акумулирати, аклиматизирати/аклиматизовати, дезорганизирати/дезорганизовати, деранжирати, дегустирати, емигрирати итд. у поређењу с другим словенским језицима.
} 
768. Pavlović Zvezdana, Onomastički derivati izvedeni iz lekseme gost u slovenskim jezicima, Прва југословенска ономастичка конференција, ЦАНУ, Титоград, 1976, 71-75.

769. Павловић Звездана, Суфиксални творбени модел -штица и његове варијанте у српскохрватској хидронимији, ОП I, 1979, 119-127.

770. Павловић Звездана, Оними са основом стрж-, НJ XXXI/1-5, 1996, 133-136.

771. Павловић Јелена, Речи изведене од заменице свој, in: Ślady obcego panowania w języku, kulturze i świadomości narodów południowosłowiańskich, Materiały z konferencji naukowej Kraków, 24 maja 2010, Kraków, 2011, 59-68.

772. П[авловић] М[иливој], Конструктор - деполатор, НJ VII/2-3, 1940, 81.

773. П[авловић] М[иливој], Ширење инфинитива типа -ирати, НJ VII/2-3, 1940, $81-82$.

774. П[авловић] М[иливој], Из техничког речника, НJ VII/2-3, 194, 82-83.

775. Павловић Миливој, Значење придева с наставком -аст и юегових варијаната, HJ IV/1-2, 1952, 9-24.

776. Павловић Миливој, Значење придева с наставком -аст и његових варијаната, HJ IV/3-4, 1952, 99-114.

777. Павловић Миливој, Значење придева с наставком -аст и његових варијаната, HJ IV/5-8, 1953, 175-195.

778. Павловић Миливој, Апстрактне именице с наставком -ост, HJ IV/9-10, 1953, 296-307.

779. Павловић Миливој, Опозитно условљена деминутивност, ЈФ XXIV, 1959-1960, 225-230.

780. Павловић Миливој, Борба наставака у српскохрватском језику, ГФФНС VI, $1961,164-179$

781. Павловић Миливој, Структурално условљен семантички опозитум, in: Проблеми синтаксе и језички динамизам, Београд, 1972: ЗУНС, 185-191.

782. Panzer Baldur, Handbuch des serbokroatischen Verbs, Derivation, Heidelburg, 1991.

783. Panzer Baldur, Das Derivationswörterbuch des serbokroatischen Verbs, in: Theorie und Praxis des lexikographischen Prozesses bei historischen Wörterbüchern, Lexicographica Series Maior 23, Hrsg. H.E. Wiegand, Tübingen 1987, 237-244.

784. Panzer Baldur, Derivationskategorien des serbokroatischen Verbs, in: Slavistische Studien zum X. Internationalen Slavistenkongreß in Sofia 1988, Köln- Wien 1988, 169-184 [= Studien zum slavischen Verbum, Heidelberg 1991, 217-230].

785. Paunov A[leksandar], ,, Tačka gledišta ${ }^{98}$ HJ/I, 1933, $273-274$.

786. Paunov Aleksandar, O deminutivima, J XIX, 4-5, 1972, 157-159.

787. Пејановић Б. Ана, Фразеолошке јединище као мотиватор у творбеном проце$c y, i n:$ Творба речи и њени ресурси у словенским језицима, Зборник радова са четрнаесте међународне научне конференције Комисије за творбу речи Међународног комитета слависта, Београд, 2012: Филолошки факултет, 689-700.

788. Перваз Драгиња, Енглеске скраћенице у српском језику, ${ }^{99}$ in: О лексичким позајмљеницама, Суботица-Београд, 1996: ГБС - ИСЈ САНУ, 105-119.

789. Perković Mirko, Neke mjesne vlastite imenice za žensku čeljad, HJ VII/5, 1940, 169-171.

790. Петровачки Љиљана, Штасни Гордана, Именичке полусложенице у српском језику, ГФФНС XXXIV/1, Нови Сад 2009, 89-102.

\footnotetext{
${ }^{98} \mathrm{O}$ суфиксу -иште, генетски и нормативно интонирано.

${ }^{99}$ Разликује алфабетизме (изговарају се слово по слово, нпр. $\mathrm{CNN}-\mathrm{cu} \mathrm{ен} \mathrm{ен)} \mathrm{и} \mathrm{акрониме}$ (изговарају се као целе речи, нпр. NATO - нато).
} 
791. Petronijević Božinka, Konnotation in translations linguistiseher Sicht, illustriert am Beispiel des serbokroatischen Augmentativus im Deutschen, ЗбМСФЛ ХХХV/2, 1992, 169-177.

792. Petronijević Božinka, Neke novine u nauci o tvorbi reči, ЗбМСФЛ XXXVII, 1994, 469-479.

793. Петронијевић Божинка, Компаращија префиксално придевско-прилошких деривата, CJ XV/1-2, 2010, 63-75.

794. Петронијевић М. Божинка, Циркумфикс-статус и функција у немачком и српском језику, CJ XXIV, 2019, 147-162.

795. Петровић В. В., Речи изведене од основе магнет, ${ }^{100}$ НJ III/9-10, 1951-2, 322-325.

796. Петрухина Васильевна Елена, Использование словообразовательных ресурсов церковнославянского языка в современном русском языке (в сопоставлении c сербским языком), in: Творба речи и њени ресурси у словенским језицима, Зборник радова са четрнаесте међународне научне конференције Комисије за творбу речи Међународног комитета слависта, Београ, 2012: Филолошки факултет, 271-287.

797. Петрушевски Д. Михаил, О пореклу и постанку српских, односно хрватских имена на-САВ(А), ОП I, 1979, 35-43.

798. Пецо А/сим/, Двојаки облици једног изведеног придјева, НJ XIV/1, 1964, 49-54.

799. Пецо Асим, Козарске бригаде и козарачке бригаде, in: Језик наш свагдашњи, Сарајево, 1969, 136-137.

800. Пецо Асим, Неке напомене о префиксално-суфиксалном типу топонима, ЗбМСФЛ ХVI/2, 1973, 197-200.

801. Peco Asim, O nekim specifičnostima zapadnobosanske antroponimije: hipokoristici tipa Hase, Fate, Kadro, JФ 34, 1978, 89-109.

802. Peco Asim, Morfološka i prozodijska uobličavanja orijentalnih imena ženskoga roda u srpskohrvatskom jeziku, ČJOK, 409-418.

803. Peco Asim, O jednom tipu naših hipokoristika, Onomastica Jugoslavica 10, Zagreb, 1982, 177-180.

804. Пецо Асим, Творбени процеси у области српскохрватских оријентализама, ${ }^{101}$ НССВД 16/1, 1987, 83-92.

805. Пецо Асим, Творба Вукових турцизама, in: Турцизми у Вуковим рјечницима, 1987, 219-222.

806. Peco Asim, Višeznačnost izvedenica sufiksom -uša u srpskohrvatskom jeziku, Studia phraseologica, München, 1992, 397-406.

807. Пецо Асим, Вишезначност изведеница суфиксом -уша у српскохрватском јези$\kappa y$, ЗбМСФЛ XXXVIII/2, 1996, 149-156.

808. Пецо Асим, Именице на -еж у намем језику (поријекло, значеъе и акиенат), ЈФ LII, 1996, 41-55.

809. Пецо Асим, Именице на -ура у нашем језику, НJ XXXI/1-5, 1996, 146-162.

810. Пецо Асим, Именице на -ш у нашем језику - постанак и значење, Четврти лингвистички скуп „Бошковићеви дани”, ЦАНУ, Подгорица, 1999, 15-36.

811. Пецо Асим, Префиксални и префиксално-суфиксални топоними типа Подбрдо $u$ Подбрђе, CJ V/1-2, 2000, 233-237.

\footnotetext{
${ }^{100}$ Покушава доказати како је глагол магнетити једнако раширен у српском као и магнетисати.

${ }^{101} \mathrm{O}$ изведеним именицама, придевима и глаголима са основама оријенталног порекла, те о именицама са суфиксима -иија, -лија, -лук, -хана/-ана и придевима на -ли.
} 
812. Пешикан Митар, О грађењу имена становника у односу на имена земаља и места, HJ IX/5-6, 1958, 196-205.

813. П[ешикан] М[итар], Језичке поуке, ${ }^{102}$ НJ X, 1960, 180-181.

814. Пешикан Митар, Јоми о акценту презимена на -овић (-евић), НJ XXI/3, 1975, $183-186$

815. Пижурица Мато, Из дијалекатске творбе пејоратива, in: Лексикологија и лексикографија, зборник радова, Нови Сад-Београд, 1984: Матица српска, 129-135.

816. Pintarić Neda, Tvorbeni postupci u poljskom i hrvatskom razgovornom jeziku, F 55, 2010, 89-104.

817. Појатић Дурија, Основна питања творбе ријечи у руском и српском језику, СЈ IV/1-2, 1999, 469-480.

818. Pomianowska Wanda, Razlike u pogledu tvorbe reči u nazivima nosilaca zanimanja и južnoslovenskim dijalektima, ЗбМСФЛ ХІІ, 1969, 25-41 [+ три карте].

819. Pomianowska Wanda, Razlike u pogledu tvorbe reči u nazivima nosilaca zanimanja u južnoslovenskim dijalektima II, ЗбМСФЛ ХІІІ/1, 1970, 165-184.

820. Поповић Љубомир, Деривациона конгруенција у броју код одредбених именица, НССВД 13, 1983, 55-71.

821. Поповић Марко, Ка могућој класификачији страних речи с најучесталијим префиксима грчког и латинског порекла, НJ XXIX/5, 1994, 279-300.

822. Popović Miljenko, Treba li bilježiti nastavak u tvorbenoj analizi?, J XXVIII/1, 1980, 31-32.

823. Поповић Михаило, Суфиксална творба именииа код основа франиуског порекла, НССВД 26/2, 1997, 329-337.

824. Прањковић Иво, Божо Ћорић, Моциони суфикси у српскохрватском језику (Библиотека Монографије Филолочког факултета Београдског универзитета, Београд, 1982), КJ XII/1, 1983, 47-50.

825. Предић Св[етислав], О грађену и транскрибовању неких речи латинског порекла, НJ V/1-2, 1953-1954, 27-34.

826. Прћић Твртко, Прилози за једну савремену теорију творбе речи - продуктивност, ГФФНС 27, 1999, 71-81.

827. Putanec Valentin, Dva naša sufiksa turskog porijekla: -alija/-ajlija, 2. -ahija/-alija, Ivšićev zbornik, Zagreb, 1963, 295-302.

828. Putanec Valentin, O našem pridjevskom sufiksu -an < -en, F 5, 1967, 117-122.

829. Putanec Valentin, Bilješka o funkcionalnosti sufiksa -aći, J XXV/1, 1977, 20-22.

830. Putanec Valentin, Aloglotni antroponimini sufiksi -ojlo, -ojla u hrvatskoj ili srpskoj antroponimiji, ČJOK, 437-447.

831. Putanec Valentin, Hrvatski antroponimni sufiksi očuvani u toponimiji zagrebačke regije, Onomastica Jugoslavica 10, Zagreb, 1982, 191-194.

832. Радан Михај, Творбени модели карашевских хипокористика, in: Лексикологија, ономастика, синтакса (Зборник у част Гордане Вуковић), Нови Сад, 1011, 257-268.

833. Радић Дугоњић Милена, Творбено-семантички процеси у лексищи из области информатике, in: О лексичким позајмљеницама, Суботица-Београд, 1996: ГБС - ИСЈ САНУ, 320-326.

834. Радић Јованка, О творбеној структури етника (на примерима из централне Србије), CJ IV/1-2, 1999, 749-757.

835. Радић Јованка, Суфиксне интеракиије у топонимији, СЈ 7/1-2, 2002, 471-477.

836. Радић Јованка, Префиксална творба речи - дериваиија или композииија, наставни и ваннаставни аспект, НJ XXXVI/1-4, 2005, 54-67.

${ }^{102} \mathrm{O}$ творби етника суфиксима -ац, -анац, -анин. 
837. Радић Јованка, Пол и категоријална припадност назива за лица у српском језику, Шездесет година Института за српски језик САНУ, Зборник радова I, Београд, 2007, 381-400.

838. Радић Ј. Јованка, О категоријалним вредностима творбених морфеме, (на примерима типа Церина, иеретина, иеровина), СJ XXI, 2016, 183-202.

839. Радић Првослав, Именички деминутивни суфикси -че $u$-иче у говору села Милошева у Великом Поморављу, Начини творбе изведенииа, ЈФ XL, 1984, 149-165.

840. Радић Првослав, Творбено-семантичке особености изведеница са суфиксом -че на делу балканизираних јужнословенских говора, АФФ 18, 1987, 227-236.

841. Радић Првослав, Поглед на творбу речи у делима Гаврила Стефановића Венцловића, НССВД 16/1, 1987, 43-50.

842. Радић Првослав, Суфикси несловенског порекла у Вуковом „Српском рјечнику” из 1852. године, НССВД 17/1, 1988, 293-300.

843. Радић Првослав, Глаголске именице на -ње $u$-ће $I$, КњJ XXXV/1, 1988, 47-54.

844. Радић Првослав, Глаголске именище на -ње $u$-ће II, КњJ XXXV/2, 1988, 128-136.

845. Радић Првослав, Ружић Мирослава, Из творбе девербативних именица у делима Гаврила Стефановића Вениловића (именице апстрактнога значења), ЗбМСФЛ ХХХІІ/1, 1989, 93-101.

846. Радич Пьрвослав, Умалителните производни от типа облаче $и$ венче в трудовите засягаши въпросите на словообразуването в българския и сърбохърватския език (От гледна точка на противопоставянето при словообразуването), Втори международен конгрес по българистика, 23, Млади българисти - колоквиум, БАН, София, 1989, 114-119.

847. Радић Првослав, Балканистички суфикси као стилска средства у српском къижевном језику (на примеру изведеница са суфиксом -лија), НССВД 23/2, 1995, $143-152$.

848. Радић Првослав, Из проблематике творбе речи у српском књижевном језику (нормативистички аспект), Знамен 2, Филозофски факултет, Петриња, 1995, 47-56.

849. Радић Првослав, О деривачионом аспекту лексичког богаћења, ЈД 1, 1997, 22-24.

850. Радић Првослав, О формално-граматичком статусу образовања на -и(ја) $u$ ли(ја) у српском къижсевном језику, НССВД 26/2, 1997, 353-364.

851. Радић Првослав, Суфикс -чија/-џија у српском књижевном језику (стилско-семантички аспект), НJ XXXII/3-4, 1998, 179-191.

852. Радиќ Првослав, За еден начин на експресивизација во балканословенските говори (Придавски образувања со завршок -осан), Македонски јазик XLV-XLVII, Скопје, 1998, 179-186.

853. Радић Првослав, Суфикс -лија у грађену имена становника од имена места или области, ЈФ LV, 1999, 47-66.

854. Радић Првослав, Турски суфикси у српском језику (са освртом на стање у македонском и бугарском), Библиотека ЈФ, Београд, 2001: ИСЈ САНУ.

855. Радић Првослав, О глаголском суфиксу -иса у српском књижевном језику, Исследования по славянским языкам 7, Сеул, 2002, 229-238.

856. Радић Т. Првослав, О једном творбеном балканизму у српском језику (глаголски суфикс -оса: порекло и распрострањеност), in: Творба речи и њени ресурси у словенским језицима, Зборник радова са четрнаесте међународне научне конференције Комисије за творбу речи Међународног комитета слависта, Београд, 2012: Филолошки факултет, 701-710.

857. Радић Т. Првослав, Глаголски суфикс -оса у српском језику, CJ XVIII, 2013, 147-165.

858. Радић Т. Првослав, Суфикс -аћ у српском језику, СJ XX, 2015, 251-265. 
859. Радић Првослав, Творба речи и миксоглотија, Прилози о суфиксацији у српском језику ${ }^{103}$, Београд, 2018: ДСЈК.

860. Радић Сања, Страна препозитивна компонента е- у савременом српском језику, in: Савремена проучавања језика и књижевности IV/1 (Зборник радова ca IV научног скупа младих филолога Србије одржаног 17. марта 2012. године на Филолошко-уметничком факултету у Крагујевцу), Крагујевац 2013: Филум, 130-145.

861. Радишић $\mathrm{B}$ [укашин], Филологичный погледъ на окончанія ество, ство $u$ тво $y$ средным суштествителнымъ, $и$ ескій $и$ кій у прилагателнымъ именима, ${ }^{104}$ Србске новине, 1842. Нр 31.

862. Radovanović Milorad, Dekompozicija i univerbizacija, ЗбМСФЛ ХLVII/1-2, 2004, 43-49.

863. Радовић Тешић Милица, Именичка образоваға с префиксима над- $и$ под-, НЈ XXVI/4-5, 1985, 205-219.

864. Радовић Тешић Милица, Именичка образоваға с префиксима у српскохрватској топонимији, in: Зборник Шесте југословенске ономастичке конференције, Београд, 1987, 621-626.

865. Радовић Тешић Милица, Творба именица с префиксом не- у савременом српскохрватском језику, НССВД 16/1, 1987, 93-99.

866. Радовић Тешић Милица, Нешто о синонимији у творби неких именица, НССВД 20/2, 1991, 353-360.

867. Радовић Тешић Милица, Експанзија префиксалног елемента супер- у српском језику, in: О лексичким позајмљеницама, Суботица-Београд, 1996: ГБС-ИСЈ САНУ, 299-305.

868. Радовић Тешић Милица, Творба топонима с префиксом за-, СJ III/1-2, 1998, 65-69.

869. Радовић Тешић Милица, Именичка образовања с префиксом па- у српском јези$\kappa y$, Четврти лингвистички скуп „Бошковићеви дани”, ЦАНУ, Подгорица, 1999, 117-121.

870. Радовић Тешић Милица, Пејоративни називи за женску особу у једном народном говору, ЈФ LVII/3-4, 2000, 907-913.

871. Радовић Тешић Милица, Именице с префиксима у српском језику, Београд, 2002: ИСЈ САНУ.

872. Радовић Тешић Милица, Богаћење лексике префиксаиијом, СJ 9/1-2, 2004, 219-226.

873. Радуловић Јован, Аугментативно-пејоративна значења неких именица, НЈ VIII/3-4, 1956, 106-113.

874. Radčenko Marina, Mocijska tvroba u hrvatskom i ruskom jeziku, SL 53/4, 1/2, 2002, 195-203.

875. Rajić Ljubiša, Jezik i pol, Kultura 57/58, Beograd, 1982, 79-95.

876. Ракић Станимир, Придевски суфикси и акценат, КЈ 19/3, 1988, 121-128.

877. Rakić Stanimir, Imenički sufiksi i akcenat, ЗбМСФЛ ХХХV/1, 1992, 141-159.

878. Ракић Станимир, Правило краћења у српскохрватском језику, ЗбМСФЛ XXXIX/1, 1996, 141-156.

879. Ракић Станимир, Да ли је „китоловац” ловаи на китове?, ЗбМСФЛ XL/2, 1997, 253-258.

880. Ракић Станимир, О придевским сложеницама типа придев + именица, ЗбМСФЛ $\mathrm{XLI} / 2,1998,107-127$.

\footnotetext{
${ }^{103}$ Скуп претходно објављених радова из области суфиксације.

${ }^{104}$ Претежно о правописним питањима.
} 
881. Ракић Станимир, О нултим суфиксима и извођењу наставцима -ø, -a, -о/-е, ЗбМСФЛ XLII/1, 1999, 225-254.

882. Ракић Станимир, О лексичком слоју придевских сложеница типа придев + именица, ЗбМСФЛ XLII/1, 1999, 255-276.

883. Ракић Станимир, О дужини крајњега слога основе у придева и у других врста речи, ЗбМСФЛ XLIV/1-2, 2001, 145-165.

884. Ракић Станимир, О конверзији сложених придева у именице, НJ XXXIV/1-2, 2001, 141-144.

885. Ракић Станимир, О парадигматском извођењу глагола од именичких основа у српском језику, ЗбМСФЛ XLV/1-2, 2002, 143-183.

886. Ракић Станимир, О проблему конверзије придева у именище, НJ XXXIV/3-4, 2002-2003, 195-208.

887. Ракић Станимир, O акценту и дужини именичких сложеница, ЗбМСФЛ XLVII/1-2, 2004, 425-444.

888. Ракић Станимир, О извођењу имена становника градова и области (-анин: један суфикс или два?), ЗбМСФЛ XLVIII/1-2, 2005, 267-275.

889. Ракић Станимир, О везном вокалу и везном морфему у неким основним типовима сложенииа у српском језику, HJ XXXVI, 1-4, 2005, 35-53.

890. Ракић Станимир, О лексичком слоју именичких сложеница типа именица + именица у српском језику, ЗбМСФЛ, 2007, 767-791.

891. Rammelmeyer Matthias, Die deutschen Lehnübersetzungen im Serbokroatischen, Beiträge zur lexikologie und Wortbildung, Wiesbaden, 1975.

892. Rammelmeyer Matthias, Њемачки лексички калк и творба ријечи у српскохрватском језику, НССВД 6/1, 1977, 291-304.

893. Range Dieter Jochan, Bemerkungen zum Suffix -ana im Südslavischen, Die Welt der Slaven, Vierteljahrschrift für Slavistik, Jahrgang XIV, Heft 1, Otto Harrassowitz, Wiesbaden, 1969, 22-25.

894. Ранђеловић 3. Ана, Творбена структура именица у поезији Јована Дотеновића, HJ XLV, 2014, 89-104.

895. Распор Зеница, Систем грађења сложених именица и придева у италијанском и у српскохрватском, Живи језици XVII, Београд, 1976, 19-36.

896. Ратковић Драгана, Глаголи са интерфиксом -о/е- у савременом српском језику, HJ XL/1-4, 2009, 43-51.

897. Ратковић Драгана, Чисте именичке сложенице са интерфиксом -о/-е, ЗбМСФЛ $\mathrm{LII} / 2,2009,147-151$.

898. Ратковић Драгана, Чисте придевске сложенице са интерфиксом -о/е- у савременом српском језику, CJ XV/1-2, 2010, 481-488.

899. Ратковић Драгана, Сложено-изведене именице женског рода са интерфиксом -о/e- y савременом српском језику, in: Зборник радова Филозофског факултета, Посебно издање посвећено проф. др Милосаву Вукићевићу, Филозофски факултет Универзитета у Приштини, Косовска Митровица, 2010, 451-464.

900. Ратковић Драгана, Речи са интерфиксом -ø- (нултим интерфиксом) у српском језику, Зборник Матице српске за књижевност и језик LVIII/3, Нови Сад, 2010, 611-619.

901. Ратковић Драгана, Речи са интерфиксом -и- у српском језику са творбено-семантичког аспекта, CJ XVII/1-2, 2012, 293-303.

902. Ратковић Драгана, Речи са интерфиксом -и- у српском језику у историјском развоју до данас у поређењу са руским и пољским, НССВД 41/1, 2012, 319-330.

903. Ратковић Драгана, Лексичко-семантичке и стилске одлике императивних сложеница у српском језику, HJ XLIII/1-2, 2012, 15-28. 
904. Raecke Jochan, Die Rolle der Wortbildung im lexikon des Jargons (am Beispiel des Serbischen mit Seitenblicken auf das Russische), Словообразуване и лексикология, София, 2009, 385-400.

905. Rzetelska Feleszko Ewa, Budowa słowotwórcza naziw wodnych w lewym dorzeczu Driny ${ }^{105}$ (Na podstawie D. Vujičića, Hidronimi u lijevom slivu Drine, 1982), FOC 1, 1992, 43-54.

906. Risse Jean, A propos de quelques suffixes serbo-croates, Филолошки преглед I-IV, Београд, 1977, 115-129.

907. Ристић Олга, Функиија префикса не- у неким именичким и придевским композитама, ЈФ ХХV, 1961, 285-293.

908. Ристић Олга, Употреба суфикса -је у језику неких српских и хрватских романтичарских песника, НJ XV, 1966, 288-294.

909. Ристић Олга, Лексичко-семантичке одлике творбе именица у неких српских и хрватских романтичарских песника, ЈФ XXVIII/1-2, 1969, 219-320; 3-4, 1970, 387-451.

910. Ристић Стана, Морфема -тељ у савременом српскохрватском језику, НJ XXV/45, 1982, 189-230.

911. Ристић Стана, Морфема -тељ у комбинацији са другим суфиксним морфемама, HJ XXVI/1, 1983, 6-24.

912. Ристић Стана, Универбизаиија као средство експресивизачије разговорне лексике (на материјалу Речника нових речи И. Клајна и романа Убиство с предумишиљајем С. Селенића), JФ LI, 1995, 125-133. Прештампано у: Стана Ристић, Експресивна лексика у српском језику, Београд, 2004, 189-196.

913. Ристић Стана, Експресивна и стилска употреба збирних имениия са суфиксом -ија, НJ XXXI/1-5, 1996, 85-95. Прештампано у: Стана Ристић, Експресивна лексика у српском језику, Београд, 2004, 95-105.

914. Ристић Стана, Неке карактеристике придева са префиксима о- $и$ по- у савременом српском језику, НJ XXXIII/1-2, 1999, 57-67.

915. Ристић Стана, Јоме нека запажања о негаџији и негираним именицама, НССВД 33/1, 2004, 99-110.

916. Ристић Стана, Милосављевић Бојана, Јовановић Владан, Деминутиви са суфиксима -че $u$-(ч)ић, СЈ 10/1-2, 2005, 597-616.

917. Ристић Стана, Улога конкуренције у регулисағу лексичке и функиионално-стилске норме (на примеру именица са префиксима не-, надри- $u$ назови-), Пети лингвистички скуп „Бошковићеви дани», ЦАНУ, Подгорица, 2003, 195-206.

918. Ристић Стана, Сложенице у корпусу нових речи са творбеним елементима у значељу квантификаије, in: Зборник радова са научног скупа на Филолошкоуметничком факултету, Крагујевац, 2008, 125-139.

919. Ристић Стана, Преглед најновијих творбених процеса (по врстама речи), НЈ XXXIX/1-4, 2008, 77-90.

920. Ристић Стана, Неке најновије појаве у развоју лексике српског језика (на примеру творенииа са префиксима не- $и$ анти-), НССВД 38/1, 2009, $27-41$.

921. Ристић Стана, Творба нових речи од властитих именица, С XIII, 2009, $307-$ 315.

${ }^{105}$ Методом структуралне анализе грађа из монографије Д. Вујичића, Хидроними у лијевом сливу Дрине, подељена је у три групе: примарни називи (типа Вода), секундарни називи (типа Драгосавац) и сложени називи (типа Прачко Врело). Међу секундарним називима најчешћи су деривати на -ац и -ициа. 
922. Ристић Стана, Преглед најновијих творбених прочеса: по врстама речи, СЈ $\mathrm{XIV} / 1-2,2009,77-90$.

923. Ристић С. Стана, Улога творбе у конщептуализачији појма ВИЋЕЊЕ у језичкој слици света српског народа, in: Творба речи и њени ресурси у словенским језицима, Зборник радова са четрнаесте међународне научне конференције Комисије за творбу речи Међународног комитета слависта, Београд, 2012: Филолошки факултет, 711-726.

924. Rječnik hrvatskoga ili srpskoga jezika, I-XXIII, ${ }^{106}$ Zagreb, 1880/1882 - 1975/1976: JAZU.

925. Rogić Pavle, Lična i porodična imena u jeziku, Rad JAZU 7, 1955, 211-231.

926. Rogić Pavle, Funkcija predmetka u stvaranju novih riječi i značenja, ${ }^{107} \mathrm{~J}$ IX/5, 19611962, 106-111.

927. Rogić Pavle, Prinos mrtvih klasičnih jezika tvorbi kompozita u savremenim živim jezicima, ${ }^{108} \mathrm{~J} \mathrm{IX/5,} \mathrm{1961-1962,} \mathrm{129-132.}$

928. Родић Никола, О етнику Косовац $u$ Косовар, НJ XXI/4-5, 1975, 268-269.

929. Родић Никола, Лингвистичка суштина скраћивања имена, Прва југословенска ономастичка конференција, ЦАНУ, Титоград, 1976, 133-136.

930. Rospond Stanisław, Poludniowo-stowiańskie nazwy miejscowe z sufiksem *-itj, Kraków, 1937: PAU.

931. Rožić Vatroslav, Mjesne vlastite imenice za čeljad i pridjevi od mjesnih imenica $u$ hrvatskom jeziku, Rad JAZU 162, 1905, 135-185.

932. Савић Свенка, Принципи стварањь неологизама у српскохрватском језику, іn: Лексикографија и лексикологија, Матица српска, Нови Сад-Београд, 1984, 161-171.

933. Савић Свенка, Прагматички аспекти рода nomina agentis у српскохрватском / хрватскосрпском језику, НССВД 13/1, 1984, 247-258.

934. Svane Gunar, Nekoliko srpskohrvatskih derivata sa -1-, ЗбМСФЛ ХІХ/1, 1976, 7-17.

935. Свитлица Кристина, Именички суфикси у делима Стефана Првовенчаног, ${ }^{109}$ ППЈ 41, 2010, 5-74.

936. Sekereš Stjepan, O nekim slavonskim etnicima i kteticima, J XXII/5, 1974/1975, $156-160$.

937. Секулић Исидора, Именице које се свршавају на -ло, НЈ I/ 5-6, 1950, 178-179.

938. Селимски Людвиг, Прояви на тенденцията към интернационализация в южнославянските езици, in: Komparacja systemow i funkcjonowania wspołczesnych języków słowiańskich, 1, Słowotwórstwo / Nominacja, Opole, 2003, 103-104.

\footnotetext{
${ }^{106}$ Историјски речник. Први том изашао 1880-1882, а све одреднице у њему обрадио је Ђуро Даничић.

${ }^{107}$ У фокусу су префикси $n p a-, n p e-, n p u-$ и про- у творби глагола, именица и придева. Истиче да се само при јавља и као префикс (предметак) и као предлог у самосталној употреби.

108 Једна од најранијих прилога о структурама које у препозицији и постпозицији имају сегменте који потичу из класичних језика, као што су: aero-, antropo-, arheo-, biblio-, bio-, hromo, hrizo-, kozmo-, kripto-, ciklo-, daktilo-, demo-, dinamo-, geo-, helio-, hemo-, hidro-, hipo-, homeo-, izo-, lito-, makro-, metro-, mikro-, mono-, morfo-, neo-, oftalmo-, orto-, oro, pan(to)-, pato-, fago-, filo,. fono-, foto-, poli-, pseudo-, psiho-, piro-, tehno-, tele-, teo-, termo-, topo, tipo-, kseno-, zoo-; ana-, amfi-, ante-, anti-, apso-, arhi-, kata-, bis-, cis-, co(n)-, di-, dia-, dis-, endo-, eso-, ekso-, epi-, eks-, ekstra-, hiper-, hipo-, inter-, intra-, intro-, juksta-, meta-, para-, per-, pre-, pro-, retro-, sub-, super-, supra-, sin-, trans-, ultra-; -algija, -cefal ili-kefal, -krat(ija), -drom, -gam(ija), -gen, -graf(ija), -latrija, -lit, -log(ija), -man(ija), -nom(ija), -pat(ija), -ped(ija), -fag(ija), -fob(ija), -pter, -sfera, -skop(ija), -terapija, -tom(ija) итд.

${ }^{109}$ Констатује да неки суфикси показују висок степен продуктивности и у савременом српском језику, други су непродуктивни, док се неки препознају само као окамењени сегменти немотивисаних речи.
} 
939. Силић Јосип, Творбена структура интернационалних ријечи у хрватском или српском језику, НССВД 16/1, 1987, 59-68.

940. Silić Josip, Pranjković Ivo, Gramatika hrvatskoga jezika ${ }^{110}$ Zagreb, 2005: Školska knjiga.

941. Симић Радоје, Скраћенице - юихова структура, графија и говорна репродукuија, KJ VIII/2, 1979, 29-37.

942. Симић Радоје, Неки општи и теоријски проблеми творбене семантике у српском језику, Четврти лингвистички скуп „Бошковићеви дани”, ЦАНУ, Подгорица, 1999, 37-42.

943. Симић Радоје, Творбена структура и акиенат сложених речи са општим глаголским делом, СJ XIII/1-2, 2008, 35-62.

944. Симић Радоје, Постоје ли императивне изведенице у српском језику?, НССВД 39/3, 2010, 5-9.

945. Симић Д. Радоје, Један проблем са ивиие творбеног система српског - форме ca спојеном иртом (иртицом), in: Творба речи и њени ресурси у словенским језицима, Зборник радова са четрнаесте међународне научне конференције Комисије за творбу речи Међународног комитета слависта, Београд, 2012: Филолошки факултет, 727-735.

946. Симић Д. Радоје, О лаголској префиксаиији и префиксима, ${ }^{111}$ HJ XLVIII/3-4, 2018, 177-189.

947. Skok Petar, Leksikologičke studije, ${ }^{112}$ JФ VIII, 1928-29, 88-102.

948. Skok Petar, Turski sufiks -li u epitetima, in: Petar Skok, Leksikologijske studije, Rad JAZU 272, 1948, 39-48.

949. Skok Petar, O pridjevskim izvedenicama, PSKJ II/ 1, 1951, 12-27; II/ 2, 1952, 185-189.

950. Skok Petar, Tvorba imena stanovnika od imena naselja i oblasti, J II/3, 1953-1954, 65-69.

951. Skok Petar, Pridjevski sufiks -ički mjesto -ski, J II/4, 1953-1954, 122.

952. Skok Petar, Sufiks -irati u službenom govoru, J III/1, 1954-1955, 25.

953. Skok Petar, Pridjevske izvedenice od geografskih naziva, J III/2, 1954-1955, 33-38.

954. Skok Petar, O sufiksima -isati, -irati, -ovati, J IV/2, 1955, 36-43.

955. Skok Petar, Etimologijski rječnik hrvatskoga ili srpskoga jezika, Zagreb, 1971-1974: JAZU.

956. Смольская А[делаида] К[онстантиновна], K вопросу о дистрибуции феминных суффиксов в сербохорватском языке, ЗбМСФЛ ХVII/2, 1974, 111-117.

957. Смольская А[делаида] К[онстантиновна], Дистрибуиія фемінних суфіксів у сербськхорватській мові, Українське слов'янознанство 11, Львів, 1975, 71-75.

958. Смольская А[делаида] К[онстантиновна], Словообразование в сербохорватской топонимике, Питання сучасної ономастики, Київ, 1976, 109-115.

959. Смольская Константиновна Аделаида, Језичка норма и фемининуми у српскохрватском језику ${ }^{113}$ НССВД 10/1, 1981, 55-59.

960. Смольская Аделаида, $K$ истории суффикса -ља в сербскохорватском языке, ЗбМСФЛ ХХVI/1, 1983, 83-90.

961. Смольская Аделаида, Изменения в слобообразовательных нормах сербского литературного языка ХІХ в., ЗбМСФЛ ХXVI/1, 1983, 83-90.

\footnotetext{
${ }^{110}$ Творба речи 146-180.

${ }^{111}$ Супротставља се савременим схватањма о префиксацији као посебном виду творбе речи, односно њеном укључивању у извођење, и залаже се за схватање да све речи са префиксима треба сматрати сложенииама.

${ }^{112}$ Реч је о творби етника (и за мушкарца и за жену) кроз компаративно-историјску призму.

${ }^{113}$ Поред осталог и о изведеницама типа девојче, женче, девојченце и сл.
} 
962. Смольская Аделанда, Морфонолошке промене у грађењу речи (од Вуковог „Рјечника” до данашње лексикографије), НССВД 14/3, 1985, 55-59.

963. Смольская Аделаида, Роль омонимии в именной деривации сербскохорватского языка, ЗбМСФЛ ХХІХ/1, 1986, 127-136.

964. Смольская Аделаида, Об иноязычных суффиксах в сербохорватской феминной деривачии, ЗбМСФЛ ХХІХ/2, 1986, 105-110.

965. Смольская А[делаида] К[онстантиновна], Гибридниые модели и конкуренция славянских суффиксов (сербокорватский и русский языки), іп: Словообразование и номинативная деривацијя в славянских яыках 2, Тезисы 2 респ. научнопаркт- конф., Гродно, 1986, 158-160.

966. Смольская А[делаида] К[онстантиновна], Диахронные константы славянского именного словопроизводства и феминные суффикы в сербохорватском литературном языке, Советское славяноведение 3, Москва, 1987, 75-82.

967. Смольская А[делаида] К[онстантиновна], О словообразовательной паралексии в русском языке (в сопоставлении с сербскохорватским языком), in: Словообразование в современном русском языке, Тезисы докладов, Омск, 1988, 59-61.

968. Смольская А[делаида] К[онстантиновна], Функциональные границы и структура андронимов в современном сербохорватском языке, іп: Шоста республіканська ономастична конференція, Тези доповідей, Одеса, 1990, 112-114.

969. Смољска Аделаида, Творбене категорије и юихови архимодели, ${ }^{114}$ НССВД 20/2, 1991, 317-323.

970. Смольская А[делаида] К[онстантиновна], Развитие именного словообразования в сербохорватском языке (фемининативы), Автореферат диссертации на соискание ученой степени доктора филологических наук, Москва, 1993, 1-37.

971. Смольская Аделаида, Неке дискурсне функиије изведеница, НССВД 21/2, 1993, 78-81.

972. Смольская Аделаида, Вук Караджич и закономерности сербохорватского словообразования, ${ }^{115}$ ЗбМСФЛ ХХХІІ/1, 1994, 107-112.

973. Смольская А[делаида] К[онстантиновна], Изменения в словообразовательных нормах сербского литературного языка ХІХ в., ${ }^{116}$ ЗбМСФЛ XXXVII/1, 1994, 561-568.

974. Смольская К[онстантиновна] Аделаида, Лексички синоними творбене семантике, НССВД 22/2, 1994, 235-241.

975. Смольская Аделаида, Еволуција творбе речи у српском језику и њено проучаване, НССВД 25/2, 1996, 235-245.

976. Смольская Аделаида, Међуоднос граматичких и семантичких категорија код именииа у српском језику, НССВД 26/2, 1997, 449-455.

977. Стакић Милан, Консонантске алтерначије код именица и придева изведених суфиксима са сугласником Ј у јужнословенским језицима, АФФ XVI, 1984, 67-92.

978. Стакић Милан, Суфикс -ЂКА, -ЬКА у јужнословенским језицима, Македонски јазик XXXVI-XXXVII, Скопје, 1986, 265-284.

979. Стакић Милан, Улога перинтеграиије у јужнословенској именској деривацији, НССВД 16/1, 1987, 177-183.

980. Стакић Милан, Прасловенски деминутивни суфикс -ЂКЪ у јужнословенским језицима, АФФ XVIII, 1987, 219-225.

981. Стакић Милан, О пејоративима у Вуковом Рјечнику, НССВД 17/1, 1987, 153-159.

\footnotetext{
${ }^{114} \mathrm{O}$ творбеном типу, творбеном моделу и творбеном обрасцу.

${ }^{115}$ Предмет расправе су деривати са значењем особе женског пола (именичка моција).

${ }^{116}$ Предмет расправе су деривати са значењем особе женског пола (именичка моција).
} 
982. Стакић Милан, Деривациона терминологија у српскохрватском језику (основни појмови), НССВД 18/1, 1988, 83-87.

983. Стакић Милан, Семантичка компонента развитка именских суфикса у радовима професора Радосава Бошковића, Први лингвистички научни скуп у спомен на Радосава Бошковића, (Даниловград 1987), ЦАНУ књ. 17, Одјељење умјетности, књ. 6, Титоград, 1988, 177-183.

984. Стакић Милан, Деривациона фонетика именица и придева у јужнословенским језииима, Београд, 1988: Филолошки факултет.

985. Stakić Milan, Derivaciono-fonetske osobine sufiksa -ina $i$ njegovih derivata $u$ južnoslovenskim jezicima, Radovi ANU BiH LXXXIV, 1989, 97-112.

986. Стакић Милан, Консонантске алтернащије изведених именица и придева у јужнословенским језицима, АФФ ХІХ, 1992, 157-175.

987. Стакић Милан, Творбени ликови и синтаксичке функције апстрактних именица у Андрићевом роману На Дрини ћуприја, Књ $41 / 1-2,1994,25-30$.

988. Стакић Милан, Деривациони морфонолошки дублети у српском језику, СЈ I/1-2, 1996, 149-162.

989. Стакић Милан, Видови дериваџионе основе именских речи у српском језику, Књ 45/4, 1997, 11-16.

990. Стакић Милан, Деминутиви на -ица са деривационом основом на -j (прилог нормирағу „структуралног” Ј у додиру са И), Трећи лингвистички скуп „Бошковићеви дани,” Подгорица 1997, 87-93.

991. Стакић Милан, Врсте речи и структура деривационе основе именица и придева у српском језику, НССВД 27/2, 1998, 273-278.

992. Стакић Милан, Дериваџиона фонетика - у ужем смислу, СЈ III/1-2, 1998, 109-124.

993. Стакић Милан, Придевски суфикс-ски, CJ IV/1-2, 1999, 409-418.

994. Стакић Милан, Семантичко диференцирање деривационих дублета, Четврти лингвистички скуп „Бошковићеви дани”, Подгорица, 1999, 173-181.

995. Стакић Милан, Синонимност суфикса и юихово семантичко диференщирање, CJ VI/1-2, 2001, 393-399.

996. Стакић Милан, Морфонологија и дериващија: чланции и расправе, Београд, 2002: Филолошки факултет.

997. Стакић Милан, Суфикс-арош, in: Србистички прилози (Зборник у част професора Славка Вукомановића), Београд, 2005, 243-248.

998. Стакић В. Милан, Именички суфикс -ство у српском језику, CJ XXIV, 2019, 357-373.

999. Станић Данијела, О неким творбеним типовима променљивих придева који означавају боје, HJ XLIII/1-2, 2012, 29-44.

1000. Станић Данијела, Придеви са именичком основом који означавају боје, in: Савремена проучавања језика и књижевности III/1, Крагујевац 2012, 165-174.

1001. Станић Т. Данијела, Лексичко-семантичка и творбено-граматичка анализа глагола са префиксом пона-, СJ XX, 2015, 481-494.

1002. Stanić Milija, Složenica i prosta reč, PSKJ 5, 1957, 96-98.

1003. Станић Милија, Акценат презимена на -овић (-евић) са двосложном и вишесложном основом, НJ XXI/3, 172-183.

1004. Станојчић Живојин, Есочентричне придевске сложенице у српскохрватском књижевном језику, ЗбМСФЛ XXVII-XXVIII, 1984-1985, 727-732.

1005. Станојчић Живојин, О перспективи једног творбеног модела код придева у сриском књижевном језику, Трећи лингвистички скуп „Бошковићеви дани”, ЦАНУ, Подгорица 1997, 73-77.

1006. Станојчић Живојин, Префикси без- и не- у сложеницама с именицом, НССВД 29/1, 2000, 153-160. 
1007. Станојчић Живојин, Граматика српског књижевног језика, ${ }^{117}$ Београд, 2010 : Креативни центар.

1008. Станојчић Живојин, Поповић Љубомир, Граматика српског језика за гимназије и средње школе, ${ }^{118}$ Београд, ${ }^{14} 2012$ : Завод за уџбенике.

1009. Станојчић Живојин, Семантичке и морфонолошке основе настанка једног (могућег) творбеног модела (српско психолог : *исихолошкиња), Осми лингвистички скуп „Бошковићеви дани”, ЦАНУ, Подгорица 2012, 5-9.

1010. Станојчић Живојин, Прилог дескриптивно-нормативној граматици -класификација неких суфикса (суфикси -иња и -киња: структурни детерминативни), CJ XIX, 2014, 555-560.

1011. Станојчић Живојин, О творби глагола у српском језику - са посебним освртом на семантику и творбена средства означавања глаголског вида, in: Семинар српског језика књижевности и културе, Предавања 3, Београд, 2014: Међународни славистички центар на Филолошком факултету, 15-27.

1012. Stachowski Stanisław, Przyrostki obcego pochodzenia w jezyku serbochorwackim, Krakow, 1961: Uniwersytet Jagielloński.

1013. Стевановић М[ихаило], Двојство облика посесивних придева и заменица на -ов $u$-ин, НЈ I/1-2, 1949, 24-38.

1014. Стевановић М[ихаило], Постанак и значење именица на -ло, НJ I/5-6, 1950, 180-190.

1015. Стевановић М[ихаило], Деминутиви с наставком -ић (и -чић), НJ III/1-2, 1952, 6-11.

1016. Стевановић М[ихаило], Замаскирати, закамуфлирати... сконцентрисати, НЈ III/9-10, 1952, 303-308.

1017. Стевановић М[ихаило], Род и облици промене сложених скраћеница, ${ }^{119} \mathrm{HJ} \mathrm{V} / 1-2$, 1954, 18-26.

1018. Стевановић М[ихаило], О сложеницама типа „народнорепубликанаи” и поводом њих, HJ VI/5-6, 1955, 153-159.

1019. Стевановић М[ихаило], Императивне сложенице, НJ VIII/1-2, 1956, 6-18.

1020. Stevanović Mihailo, Sintaksički odnos delova izvedenih imenica, Ivšićev zbornik, Zagreb, 1963, 335-339.

1021. Стевановић М[ихаило], Придеви с наставцима -ив и -љив, НЈ XIII/3-5, 1963, 197-207.

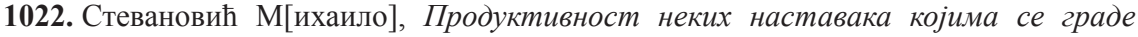
nomina agentis, HJ XIV/1, 1964, 1-19.

1023. Стевановић М[ихаило] Граматика српскохрватског језика за гимназије, ${ }^{120}$ Цетиње, ${ }^{7} 1971$ : Обод.

1024. Стевановић М[ихаило] Савремени српскохрватски језик (Граматички системи и књижевнојезичка норма) $I,{ }^{121}$ Београд, ${ }^{4} 1981$.

1025. Стијовић Светозар, Његомеве кованице, НССВД 18/2, 1990, 469-474.

1026. Стијовић Рада, Префиксачија придева у српскохрватском књижевном језику, ЗбМСФЛ ХХVI/1, 1983, 99-130.

1027. Стијовић Рада, О компаративу придева с префиксима о- $и$ по-, НJ XXXI/1-5, 1996, 106-109.

\footnotetext{
117 Творба речи 195-261.

${ }^{118}$ Творба речи 137-188.

${ }^{119}$ Скраћенице се посматрају из граматичке (морфолошке) перспективе, а не творбене.

${ }^{120}$ Грађење речи 235-272.

${ }^{121}$ Творба речи 387-591.
} 
1028. Стојановић Љ. Милица, Редупликација глаголског префикса по- у српском јези$\kappa y,{ }^{122} \mathrm{HJ}$ XLVI/1-2, 2015, 35-50.

1029. Стојановић Смиљка, Конкуренција афиксалних морфема у српском језику у поређењу са енглеским, НССВД 29/1, 2000, 203-213.

1030. Stojković Marijan, Akcenat glagolskih imenica, Rad JAZU 309, 1956, 5-32.

1031. Суботић Јелисавета, Суфикс -јь у неким мјесним именима Његотеве Црне Горе, in: Црногорски говори (резултати досадашњих истраживања и даљи рад на њиховом проучавању), Титоград, 1984: ЦАНУ, 205-209.

1032. Сурдучки Милан, Именичке сложенице без спојног вокала у српскохрватском језику, НССВД 7/1, 1981, 189-197.

1033. Сурдучки Милан, Модели јукстапозитивних именичких сложеница у предвуковском периоду (Сложенице без спојног вокала у славено-сербском), НССВД 8/1, 1982, 201-212.

1034. Tafra Branka, Konverzija kao gramatički i leksikografski problem, F 30-31, 1998, 349-361.

1035. Tafra Branka, Košutar Petra, Rječotvorni modeli u hrvatskom jeziku, SL 67/1, 2009, 87-107.

1036. Težak Stjepko, Etnici i ktetici u pravopisnom rječniku, J XXI/2, 1973/1974, 52-55.

1037. Težak Stjepko, Babić Stjepan, Gramatika hrvatskoga jezika (Priručnik za osnovno jezično obrazovanje), Zagreb 2007: Školska knjiga.

1038. Težak Stjepko, O upotrebi glagolskih imenica, J XXIII/5, 1976, 129-139.

1039. Tekavčević Pavao, O jednom tipu dvočlanih složenica u hrvatskom ili srpskom $i$ talijanskom jeziku, ${ }^{123} \mathrm{~F} 16,1988,145-150$.

1040. Терзић Александар, Структурно-семантичке одлике глаголских именица творбеног типа -ние, -ение у руском и -ње, -ће у српскохрватском језику, АФФ IX, 1969, 27-93.

1041. Терзић Александар, Структурно-семантичке карактеристике глагола са префиксалном групом пона- у руском и српском језику, НССВД 26/2, 1997, 309-320.

1042. Терзић Александар, Структурно-семантичке карактеристике глагола са префиксалном групом пона- у руском и српском језику, НССУВД 26/2, 1997, 309-320.

1043. Терзић Богдан, Nomina agentis с формантом -ар у српскохрватском и руском језику, Књ ХХXXII/1-2, 1985, 63-68.

1044. Терзич Богдан, Образованиа с суффиксом -тель в русском языке и их сербохорватские эквиваленты, ЗбМСФЛ 30, 1986, 105-111.

1045. Терзич Богдан, Существительние на -тель как мотивирующие основы в русском и сербохорватском словообразовании, ЗбМСФЛ 34, 1988, 137-143.

1046. Терзић Богдан, Један тип руских суфиксоидалних сложеница у терминолоикој функиији и юихово транспоновање на српскохрватски језик, НССВД 18/1, 1990, 171-177.

1047. Терзић Богдан, Наше изведенице на -аш и юихови руски структурно-семантички еквиваленти, НССУВД 22/2, 1991, 243-250.

122 У раду се анализирају глаголи у којима се јавља контактна редупликација префикса по-. Циљ рада је да се на основу семантичке анализе глагола истражи да ли формална редупликација подразумева и семантичку редупликацију, тј. да ли поновљени префикси функционишу са истим значењем.

${ }^{123} \mathrm{O}$ морфолошкој и семантичкој страни формација типа хрватскосрпског gore-dolje, zbrdazdola, povuci-potegni, danas-sutra, hoćeš-nećeš, navrat-nanos, povuci-potegni, kad-tad, kako-tako, kakav-takav, koliko-toliko, pošto-poto, tamo-amo,više manje и сл. и њиховим еквивалентима у талијанском. 
1048. Терзић Богдан, Названия лиц с суффиксами -ец//-ац в русском и сербохорватском языках, in: Руско-српске језичке паралеле, Београд, 1999, 85-100.

1049. Терзић Светлана, Суфикс -ац у категоријама nomina agentis и његови еквиваленти у руском језику, Зборник радова Учитељског факултета 3, Ужице, 2002, 191-213.

1050. Терзић Светлана, Суфикс -тель у руском језику и његов српски еквивалент -тељ за обележавање лица у категорији nomina agentis, Зборник радова Учитељског факултета 10, Ужице, 2008, 359-372.

1051. Тешић Милосав, Подации анкете о акиеенту презимена на -овић (-евић), НЈ XXI/3, 1975, 186-193.

1052. Тир Михал, Творба именица женског рода од назива особа мушког рода у српском језику у поређењу са словачким, НССВД 36/1, 2007, 379-385.

1053. Тиртова Галина П[авловна], Још једном о творбеном статусу именица баснодром, ракетодром, НJ XXVIII, 4-5, 1990, 309-312.

1054. Тихонов Николаевич Александр, Лексические и словообразовательные гнезда как единицы сравнительного изучения восточнославянских языков, in: Теоретические и методологические проблемы сопоставительного изучения славянских языков, Москва 1994: Наука, 148-178. ${ }^{24}$

1055. Тыртова Галина Павловна, Об определении статуса посткорневых интернациональных элементов в сербохорватском языке, Slavica Tarnopolensia 1, 1994, 53-58.

1056. Тяпко Галина Георгиевна, Собирательные существительные в сербскохорватском языке, Славянская филология 3, Лениград, 1975, 161-164.

1057. Тяпко Галина Георгиевна, Имена существительные с суффиксом -ад в современном сербскохорватском языке (комплексный анализ), Автореф. дис. ... канд. филол. наук. Москва 1978: МГУ, $21 \mathrm{c.}$

1058. Тяпко Галина Георгиевна, Словообразовательные типы nomina abstracta в сербском литературном языке первой половины XIX в. (на материале произведений B. Караджича), in: Славянское и балканское языкознание, Проблемы лексикологии, Москва: Наука, 1983, 54-69.

1059. Тяпко Галина Георгиевна, Утищај Вукове реформе на промену системских веза у српској апстрактној лексищи у доба препорода, ${ }^{125}$ ЗбМСФЛ ХХХІІ/1, 1989, 113-124.

1060. Тяпко Галина Георгиевна, Номинационный поиск в переводческой практике $B$. C. Караджича (Имена существительные), in: Вопросы языковых контактов и сопоставительное изучение языков, Москва, 1992: МГИМО, 120-151.

1061. Тяпко Галина Георгиевна, О методике исследования развития словарного состава сербского литературного языка первой половины XIX века (на материале абстрактной лексики), in: Традиция и новые тенденции в развитии славянских литературных языков: проблема динамики нормы, Тезисы докладов международной научной конференции (Москва, 24-26 мая 1994 г.), Москва 1994: Ин-т славяноведения и балканистики РАН, 1994, 51-4.

1062. Тяпко Галина Георгиевна, Номинационный поиск в творческом наследии выдающихся деятелей сербской культуры - В. С. Караджича, Дж. Даничича и Д. Обрадовича (сопоставительный обзор на материале абстрактной лексики), Терминоведение 1, Москва, 1994, 112-116.

${ }^{124}$ У раду, који је посвећен источнословенским језицима, расправља се и о појединостима из српско(хрватско)г језика (у питању су конструкције типа бланко-потпис, кромпир-чорба, ирвенперка, снек-бар, жиро-рачун, термос-боца, жена-херој, жар-птица итд.).

${ }^{125} \mathrm{У}$ центру пажње су nomina abstracta attributivitatis, а међу њима и изведенице на -ост. 
1063. Тяпко Галина Георгиевна, Особенности структуры пуристических неологизмов в словаре В. Михайловича «Пуризмы от Орфелина до Вука», Словарь и культура. К столетию с начала публикации «Словаря болгарского языка» Н. Герова. Материалы международной научной конференции (Москва, ноябрь 1995 г.). Москва, 1995: Ин-т славяноведения и балканистики РАН, 46-50.

1064. Тяпко Галина Георгиевна, Обрада семантике придевских изведеница са суфиксима -ота и -о?а у "Српском рјечнику» (1818) В. С. Кара? и? а и особине ?иховог функциониса? а у почетној фази српског к? ижевног језика, НССВД 26/2, 1997, 263-269.

1065. Тяпко Галина Георгиевна, $О$ влиянии культурного кода языка на структуру номинативных единиц (На материале русских nomina abstracta $u$ их сербских эквивалентов в переводах Дж. Даничича), in: Славянское и балканское языкознание (Проблемы лексикологии и семантики, Слово в контексте культуры), Выпуск посвящен памяти академика Никиты Ильича Толстого, Москва 1999: ИНДРИК, 183-202.

1066. Тяпко Галина Георгиевна, О функиионально-стилистическом расслоении словообразовательной категории nomina abstracta attributivitatis в славянских языках (На материале сербского и хорватского литературно-языковых идиомов), in: Konfrontacní studium inovacních procesu ve slovánských jazycích, Praha,1999, Slavia 68, Sešit 1: AVČR, 83-98.

1067. Тяпко Галина Георгиевна, Сложные имена существительные в языке сочинений Досифея Обрадовича (тезисы доклада), in: Научно-методический совещание-семинар преподавателей славянских языков, Светлогорск, 13-14 октября 2000, Информационные и научные материалы, Калининград 2001: Изд-во Калининградского гос. ун-та, 19-21.

1068. Тяпко Галина Георгиевна, О развитии словообразовательной категории отвлеченного признака в сербском литературном языке, Слов'янський збірник IX, Відп. ред. А. К. Смольська, Одеса, 2002, 64-76.

1069. Тяпко Галина Георгиевна, Имена качества в "Сербском словаре» Вука Караджичa, in: Исследование славянских языков в высшей школе: достижения и перспективы (Информационные материалы и тезисы докладов международной научной конференции 21-22 октября 2003 г. Под ред. В. П. Гудкова, А. Г. Машковой, С. С. Скорвида), Москва, 2003: МГУ, 215-217.

1070. Тяпко Галина Георгиевна, Источники обновления абстрактной лексики в сербском и хорватском языках на современном этапе, in: Procesy innowacyjne w jezykach slowianskich, Prace Slawistyczne 114, Warszawa, 2003: SOW, 231-244.

1071. Тяпко Галина Георгиевна, Развитие категории качества в сербском литературном языке (На материале «Сербского словаря» Вука Караджича), Слов'янський збірник X (Міжслов'янські мовні та літературні зв'язки, Відп. ред. А. К. Смольська), Одеса, 2003, 114-124.

1072. Тяпко Галина Георгиевна, Качественные прилагательные в «Сербском словаре» Вука Караджича, in: Славянский вестник филологического факультета МГУ 2 (К 70-летию В. П. Гудкова, под ред. Н. Е. Ананьевой и 3. И. Карцевой), Москва, 2001: МАКС Пресс, 393-405.

1073. Тяпко Галина Георгиевна, Развитие отвлеченной лексики в сербском литературном языке (Монография), Москва, 2005: МГИМО -Университет.

1074. Тяпко Галина Георгиевна, Отвлеченная лексика в сербском литературном языке в начальный период его формирования, Автореф. дис. ... доктор филол. наук. M., 2006, 44 c. 
1075. Топоришич Јоже, Контрастивни поглед на творбу речи српскохрватског и словеначког језика, НССВД 7, 1981, 167-175.

1076. Тошовић Бранко, (Псеудо)императивност глаголских композита у словенским језицима, C II, 1998, 30-44.

1077. Tošović Branko, Глагольность ономастических композитов/Die Verbalität onomastischer Komposita, in: Słowiańskie composita antroponimiczne, Lublin, 2000, 271-289.

1078. Tošović Branko, Сложные глаголь, in: Słowotwórstvo a inne sposoby nominycji (Словообразование и другие способы номинации), Katowice, 2001, 111-122.

1079. Тошовић Бранко, Деривациони однос глагола и именица у српском језику, НССВД 30/1, 2002, 39-52.

1080. Тошович Бранко, Словообразовательный корреляционал: категориальные отношения, in: Праблемы тэорыі і гісторыі славянскага словаўтварэння, Мінск, 2004, 133-155.

1081. Тошович Бранко, Деривационные различия между сербским, хорватским и бошняиким языками (прелиминариум), in: Функцыянальныя аспекты словаўтварэння, Мінск, 2006, 234-246.

1082. Тошович Бранко, Диминутивный способ действия в русском и сербском/хорватском / бошняиком языках / Die diminutive Aktionsart im Russischen und Serbischen / Kroatischen / Bosnischen, in: Исследования по семантике 24, Уфа, 2008, 346-352.

1083. Тошович Бранко, Словообразовательная блокировка, in: Словообразуване и лексикология, Универзитетско издателство „Св. Климент Охридски”, София, 2009, 351-364.

1084. Тошович Бранко, Нанизывание приставок в сербском, хорватском и бошняиком языках, in: Відображення історії та культури народу в словотворенні, Доповіді XII Міжнародної наукової конференції Комисії зі слов'янського словотворення при Міжнародному комітеті славістів, Київ, 2010, 286-297.

1085. Tošović Branko, Tvorbeni purizam, in: Творба речи и њени ресурси у словенским језицима, Зборник радова са четрнаесте међународне научне конференције Комисије за творбу речи при Међународном комитету слависта, Београд 2012: Филолошки факултет, 353-365.

1086. Тошович Бранко, Словообразование в интернете, интернет в словообразовании, in: Branko Tošović, Arno Wonisch (Hg.), Wortbildung und Internet: Institut für Slawistik der Karl-Franzens-Universität Graz, Kommission für Wortbildung beim Internationalen Slawistenkomitee, Graz, 2016, 419-494.

1087. Tošović Đ. Branko, Derivacioni internet, ${ }^{126}$ in: ПУТЕВИМА РЕЧИ, Зборник радова у част Даринки Гортан Премк, Уредник Рајна Драгићевић, Београд, 2017: Филолошки факултет у Београду, 373-385.

1088. Turk Marija, Tvorbene značajke kalkova (pridjevi, glagoli, prilozi), Fluminensia 14/1, Rijeka, 2002, 47-66.

1089. Tućan Fran, Kritik ili kritičar, ${ }^{127}$ HJ II/5, 1934, 133-134.

${ }^{126}$ Предлаже се заснивање интернетска творба речи као део мрежне лингвистике. Ова творбе речи требало би, према аутору, да се бави образовањем нових речи у интернету и функционисањем таквих деривата у интернету. Разликују се каузативни, утилитарни и перлокутивни деривати.

${ }^{127}$ Сматра да се могу употревљавати и наставак -ик и наставак -ичар (за шта наводи бројне примере), а да треба каткада правити разлику у значењу (по аутору физик и физичар имају различита значења). 
1090. Ћелић П. Ивана, Семантички потениијал деривационих гнезда именица интелектуалних својстава, in: Творба речи и њени ресурси у словенским језицима, Зборник радова са четрнаесте међународне научне конференције Комисије за творбу речи при Међународном комитету слависта, Београд 2012: Филолошки факултет, 737-744.

1091. Ћирић Сања, Из новије лексике: Баснодром, НJ XXVIII/3, 1989, 286-190.

1092. Čolić Mikić Ana, Word formation of blends, ${ }^{128}$ Mostariensia 19/2, Mostar, 2015, 21-36.

1093. Ćorić Božo, Kontrastivni opis tvorbenih sredstava za obeležavanje imeničke mocije u srpskohrvatskom i nemačkom jeziku, КњJ XXII/2, 1975, 267-282.

1094. Ћорић Божо, Nomina agentis на -лица с посебном нијансом значења, KJ 1/VII, 1978, 24-32.

1095. Ћорић Божо, Деривација моционим суфиксима у јужнословенским језицима, КњJ XXVII/2-3, 1979, 253-262.

1096. Ћорић Божо, Творба назива за женска бића у јужнословенским језицима, КЈ 3 , 1979, 31-41.

1097. Ћорић Божо, Eugenija Barić: Imeničke složenice neprefiksalne i nesufiksalne tvorbe, Hrvatsko filološko društvo, Znanstvena biblioteka, Zagreb, 1980, KJ XI/4, 1982, 221-224.

1098. Ћорић Божо, Суфикс -ка у моционој функиији, in: 31. југословенски семинар за стране слависте, Београд, 1980, 41-71.

1099. Ћорић Божо, O суфиксу -киња у српскохрватском језику, in: 32. југословенски семинар за стране слависте, Београд, 1981, 119-122.

1100. Ћорић Божо, Именички суфикси с иницијалним Ч, КЈ X, 4, 1981, 15-18.

1101. Ћорић Божо, О структури суфикса у јужнословенским језицима, Књ ХXIX/3-4, 1982, 226-230.

1102. Ћорић Божо, O сложеним суфиксима, Македонски јазик XXXII-XXXIII, Скопје, 1982, 718-721.

1103. Ћорић Божо, Моциони суфикси у српскохрватском језику, Београд, 1982: Филолошки факултет.

1104. Ћорић Божо, Из творбене синонимије српскохрватског језика, НССВД 12/1, 1983, 131-136.

1105. Ћорић Божо, Лингвистички и ортографски статус образовања типа Србијапревоз, Боснапромет, Истравино и сл., Преводилац II/1, Београд, 1983, 9-15.

1106. Ћорић Божо, Етник, ктетик и норма (поводом облика Козарчанин $и$ козарачки), HJ XXVI/2-3, 1984, 152-159. Прештампано у: Божо Ћорић, Лингвомаргиналије, Београд, 2009, 71-76.

1107. Ćorić Božo, Die Bildung von Oikonymen im Serbokroatischen und Deutschen, Wissenschaftliche Zeitschrift der Humbolt-Universitaet zu Berlin, 36. Jg. Berlin, 1987, Heft 2, 166-168.

1108. Ћорић Божо, Вук и творба речи, НССВД 17/1, 1988, 193-198.

1109. Ćorić Božo, Sociolingvistički status naziva za osobe ženskog pola u srpskohrvatskom jeziku, Fluminensia I/2,1989; II/1-2 (1990), Rijeka, 1990, 103-108.

1110. Ћорић Божо, О терминологији у нашој творби речи, НССВД 18/1, 1990, 75-82.

1111. Ћорић Божо, О неким творбеним моделима са становишта језичке економије, НССВД 20/2, 1991, 325-334.

128 Чланак је на енглеском. Расправља се о специфичним творбеним формацијама насталим стапањем, слепљивањем делова постојећих речи. Настали неологизми (често - индивидуализми) налазе се на крајњој периферији језика. Чланак доноси серију примера из штампаних и електронских медија, као што су: bankomat Łbanka + automat, radoholičar Łrad + alkoholičart, Apsurdistan $\longleftarrow$ apsurd + Afganistan, knjigra «knjiga + igra, и сл. 
1112. Ћорић Божо, Антропоними и творба речи, КњЈ XXXIX/1, 1992, 29-37.

1113. Ћорић Божо, Творбено и лексичко значење, НССВД 22/2, 1993, 257-263.

1114. Ћорић Божо, Легијаш није комедијаш, Политика, Београд, 13. 3.1994.

1115. Ћорић Божо, О неким специфичностима суфиксалне дериваџије именица у српском разговорном језику, КњJ XLII/1-2, 1995, 35-41.

1116. Ћорић Божо, Стилистички аспекти дериваџије, НССВД 23/2, 1995, 103-108.

1117. Ћорић Божо, Неке језичке карактеристике правних текстова половине 19. века, ${ }^{129}$ НССВД 25/2, 1996, 85-95.

1118. Ćorić Božo, Forme antroponima u publicističkom stilu savremenog srpskog jezika, Prevodilac XV, januar-decembar, 1-4, 1996, 24-28.

1119. Ћорић Божо, Кратка верзија термина, in: Стандардизација терминологије, Београд, 1996: САНУ, 53-55.

1120. Ћорић Божо, О суфиксалној универбацији у српском језику, СJ I/1-2, 1996, 6064; Прештампано у: КњJ XLV/2-4, 1997, 29-32; Божо Ћорић, Творба именииа у српском језику, Београд, 2008, 161-165.

1121. Ћорић Божо, Изведенице на -џија у Сремчевим делима, in: Књижевно дело Стевана Сремца - ново читање (Зборник радова са истоимене научне конференције), Ниш, 1997, 177-184. Прештампано у: Божо Ћорић, Творба именица у српском језику, Београд, 2008, 62-67.

1122. Ћорић Божо, Варијације у тумачењу изведених речи у једнојезичким речницима српског језика, НССВД 26/2, 1997, 343-351.

1123. Ћорић Божо, О деривачији именица у разговорном језику, Общтност и многообрзие на славянските езици (Сборник в чест на проф. Иван Леков), София, 1997, 201-205.

1124. Ćorić Božo, Međuzavisnost tipa teksta i forme antroponima u savremenom spskom jeziku, Slavia, Ročnik 66, Praha, 1997, 285-292.

1125. Ћорић Божо, Позајмљенице и врсте речи, НССВД 27/2, 1998, 253-261.

1126. Ćorić Božo, Ekspanzija nekih stranih tvorbenih elemenata u savremenom srpskom jeziku, Slavica Pragensia ad tempora nostra (Univerzita Karlova), Praha, 1998, 168172.

1127. Ћорић Божо, О једном нерегистрованом, а продуктивном суфиксу (суфикс изација), Четврти лингвистички скуп „Бошковићеви дани”, ЦАНУ, Подгорица, 1999, 63-69. Прештампано у: Исследования по славянским языкам (Корейская ассоциация славистов), бр. 4, Сеул, 1999, 239-248; Божо Ћорић, Творба именица у српском језику, Београд, 2008, 111-116.

1128. Ћорић Божо, Принциипи творбене анализе стране лексике, CJ IV/1-2, 1999, 227241. Прештампано у: Божо Ћорић, Творба именица у српском језику, Београд, 2008, 40-51.

1129. Ћорић Божо, Суфикс -ист/а/ у српском стандардном језику, НЈ XXXIII/3-4, 2000, 211-234. Прештампано у: Божо Ћорић, Творба именица у српском језику, Београд, 2008, 68-91.

1130. Ћорић Божо, Творбено-семантичка анализа именица на -изам у савременом српском језику, КњJ XLVIII/1-2, 2001, 37-56. Прештампано у: Божо Ћорић, Творба именица у српском језику, Београд, 2008, 92-110.

1131. Ћорић Божо, Суфикс -ада у савременом српском језику, CJ VI/1-2, 2001, 167175. Прештампано у: Божо Ћорић, Творба именииа у српском језику, Београд, 2008, 52-61. лексике.

${ }^{129}$ Кратко о суфиксима -ије, -ње, -тељ, -ество и др. у светлу посрбљавања рускословенске 
1132. Ћорић Божо, О појму мотивације у творби речи, Гласник 20, 2002, 41-53.

1133. Ћорић Божо, Михаило Стевановић као дериватолог - терминолошка питања, in: Живот и дјело академика Михаила Стевановића, Подгорица, 2002, 259-268.

1134. Ћорић Божо, Нека општа теоријска питања творбе речи, in: Зборник за српски језик, књижевност и умјетност II/2, Бања Лука, 2002, 91-106.

1135. Ћорић Божо, О формално-семантичкој класификацији изведеница, КњЈ, XLIX/1-2, 2002, 1-8.

1136. Ћорић Божо, Деривачиони појмовни апарат у српском језику, СЈ 7/1-2, 2002, 195-204.

1137. Ћорић Божо, Неке српско-бугарске језичке паралеле на плану творбе речи, Нуачни трудове, том. 41/1, Пловдивски университет `Паисий Хиландарски’, Пловдив, 2003, 419-427.

1138. Ћорић Божо, O појму конкуренције у творби речи, Пети лингвистички скуп „Бошковићеви дани”, ЦАНУ, Подгорица, 2003, 63-71. Прештампано у: Божо Ћорић, Творба именииа у српском језику, Београд, 2008, 219-225.

1139. Ћорић Божо, О неким новијим тендениијама у развоју српског језика на плану творбе речи, Probleme de filologie slavă (Вопросы славянской филологии/Проблеми словенске филологије) XI, Timişoara, 2003, 27-36.

1140. Ћорић Божо, Хибридизација у творби ријечи, Гласник 22, 2004, 41-51.

1141. Ћорић Божо, Тенденције ка интернационализащији, рационализащији и феминизацији у савремном српском језику, Die Welt der Slaven, Band 21, GermanoSlavistische Beiträge (Festschrift für Peter Rehder zum 65. Geburtstag), München, 2004, 63-75.

1142. Ћорић Божо, Комплексне јединице творбеног система, in: Терминолошка стандардизација лингвистичког описа савременог српског језика 2, НССВД 33/3, 2004, 55-60.

1143. Ћорић Божо, Моциона творба данас, in: Функцыянальныя аспекты словаўтварэння, Даклады IX Міжнароднай канферэнцыі Камісіі па славянскаму словаўтварэнню пры Міжнародным камітэце славістаў, Мінск/Беларусь 9-14 кастрычніка 2006. г, Мінск, 2006, 280-287.

1144. Ћорић Божо, Граматички род и питање полне дискриминаиије у језику, СЈ XI/1-2, 2006, 51-63.

1145. Ћорић Божо, Генеричка и маркирана форма назива за звања, занимања и титуле женског пола, Гласник 25, 2007, 43-50.

1146. Ћорић Божо, Актуелна питања именичке моције (звања, занимања и титуле женског рода), in: Un om, un simbol, In honorem magistri Ivan Evseev, Bucureşti, 2007, 241-250.

1147. Ћорић Божо, Традииионално и ново у творбеној терминологији, Гласник 26, 2008, 13-39.

1148. Ћорић Божо, Творба имениия у српском језику, Београд, 2008: ДСЈК.

1149. Ћорић Божо, Нека теоријско-методолошка и практична питања творбе речи, КњJ LV/3-4, 2008, 265-278.

1150. Ћорић Божо, Стране препозитивне компоненте у структури сложене номинативне јединище, in: Теоријско-методолошки оквир за модернизацију описа српског језика, НССВД 36/3, 2008, 33-59.

1151. Ћорић Божо, Творба речи у функиији пуризма, CJ XIII/1-2, 2008, 121-135.

1152. Ћорић Божо, Прасловенско *godё и његови континуанти у српском језику, Гласник 27, 2009, 13-19.

1153. Ћорић Божо, Лингвомаргиналије, Београд, 2009: ДСЈК. 
1154. Ћорић Божо, О творбеној хомонимији, in: Теоријско-методолошки оквир за модернизацију описа српског језика (II), НССВД 38/3, 2009, 11-22.

1155. Ћорић Божо, Творбено значење и лексикографија, in: Словообразуване и лексикология, Сборник доклади от Десетата международна конференция на Комисията по славянско словообразуване, Университетско издателство „Св. Климент Охридски", София, 2009, 302-310.

1156. Ћорић Божо, Језичке и/или варијантске разлике на творбеном плану, in: Бранко Тошовић (ур.), Die Unterschiede zwischen dem Bosnischen/Bosnaiakischen, Kroatischen und Serbischen (Lexik, Wortbilidung, Phraseologie), Slawische Sprachkorrelationen 2, Wien/Berlin/Münster, 2009, 297-309. Прештампано $y$ : Branko Tošović, Arno Wonisch (ur.), Srpski pogledi na odnose između srpskog, hrvatskog i bošnjačkog jezika, Graz, 2010, 27-39.

1157. Ћорић Божо, Универбизација у српском језику на фону хомонимије, in: Труды и материалы Международного научного симпозиума „Славянские языки и культуры в современном мире", НОВЫЕ ЯВЛЕНИЯ В СЛАВЯНСКОМ СЛОВООБРАЗОВАНИИ: СИСТЕМА И ФУНКЦИОНИРОВАНИЕ, МоскВа, 2010, 320-330.

1158. Ћорић Божо, Турски суфикси у јужнословенским језицима (са посебним освртом на прилике у српском), in: Відображення історії та культури народу в словотворенні, Доповіді XII Міжнародної наукової конференції Комисії зі слов'янського словотворення при Міжнародному комітеті славістів, Київ, 2010, 317-328.

1159. Ћорић Божо, Постфикс у српској творби речи, СJ XV/1-2, 2010, 549-553.

1160. Ćorić Božo, Na margini gramatike (rečca i postfiks god u srpskim i hrvatskim gramatikama), in: Branko Tošović (Hg.), Die Unterschiede zwischen dem Bosnischen/Bosniakischen, Kroatischen und Serbischen (Grammatik), Slawische Sprachkorrelationen 3, Wien/Berlin/Münster, 2010, 29-38. Прештампано у: Branko Tošović, Arno Wonisch (ur.), Srpski pogledi na odnose između srpskog, hrvatskog i bošnjačkog jezika, Graz, 2010, 133-141; Божо Ћорић, Лингвомаргиналије, Београд, 2009, $111-118$.

1161. Ћорић Божо, Андроними у Андрићевом језику, in: Branko Tošović (ur.), Das Grazer opus von Ivo Andrić (1923-1924), Graz, 2010, 335-342.

1162. Ћорић Божо, О дистрибуцији антропонимских идентификатора за особе женског пола, in: Лексикологија, ономастика, синтакса (Зборник у част Гордани Вуковић), Нови Сад - Београд, 2011, 185-189.

1163. Ћорић Божо, О лексичи турског поријекла са становишта творбе ријечи (у јужнословенским језицима), Годишњак Друштва чланова Матице српске у Републици српској 1/2011, Бања Лука, 2011, 35-51.

1164. Ћорић Б. Божо, Антропоними: систем и текст, in: Jerzy Sierociuk (red.), Słowotwórstwo słowiańskie: system i tekst, Prace Komisji Słowotwórczej przy Międzynarodowym Komitecie Slawistów, Seria 13, Poznań, 2012: Wydawnictwo PTPN, 297-304.

1165. Ћорић Б. Божо, О дериватима са значењем производа животињског порекла y српском језику, in: Творба речи и њени ресурси у словенским језицима, Зборник радова са четрнаесте међународне научне конференције Комисије за творбу речи Међународног комитета слависта, Београд, 2012: Филолошки факултет, 367-385.

1166. Ћорић Б. Божо, Језички ресурси и творба речи (на примеру једне творбено-семантичке скупине), НССВД 41/3, 2012, 5-21.

1167. Ћорић Божо, Дериваиија, лексикологија, лексикографија, Осми лингвистички скуп „Бошковићеви дани”, ЦАНУ, Подгорица 2012, 23-30. 
1168. Ћорић Б. Божо, Прилог библиографији творбе речи, НССВД 42/3, 2013, 173-253.

1169. Ћорић Б. Божо, Из дијалекатске творбе речи, НССВД 42/3, 2013, 7-14.

1170. Ћорић Б. Божо, О ициркумфиксима и ичиркумфиксачији у српској творби речи, НССВД 43/3, 2014, 235-240.

1171. Ћорић Божо, Кратак преглед творбе речи у српском језику, in: Семинар српског језика књижевности и културе, Предавања 3, Београд, 2014: Међународни славистички центар на Филолошком факултету, 93-114. Прештампано у: Путевима српског језика, књижевности и културе (Скуп слависта - предавања) 1 , Београд, 2015, 117-145.

1172. Ћорић Б. Божо, Нека питања творбе речи у славеносрпском језику, Исследования по славянским языкам, Сеул, 2014, 59-70.

1173. Ћорић Божо, О комбинованој творби речи на фону других сродних назива, in: Swetlana Mengel (Hg.), Slavische Wortbildung im Vergleich, Theoretische und pragmatische Aspekte, Berlin 2014, 446-461. Прештампано у: Зборник Матице српске за славистику 87, Нови Сад, 2015, 11-22.

1174. Ћорић Б. Божо, Из дијалекатске творбе ријечи, in: ОСМЬ ДЕСАТЬ, Сборник научных статей к юбилею И. С. Улуханова, Москва, 2015: Азбуковник, 218-224.

1175. Ћорић Б. Божо, О именицама на -изација по други пут, НССВД 44/3, 2015, 85-89.

1176. Ћорић Б. Божо, О даљој деминуцији у српском језику, in: Stramljič Breznik Irena (ured.), Manjšalnice v slovanski jezikih: oblika in vloga, Maribor, 2015, 74-87.

1177. Ћорић Б. Божо, Српски језик и медији на фону творбе речи, in: Jana Šołćina (redaktor), Słowjanske spisowne rěče a medije (Mjezynarodna konferenca Komisije za słowjanske spisowne rěče při Mjezynarodnym komiteju slawistow Budyšin/ Bautzen 2014), Budyšin/Bautzen, 2015, 98-104.

1178. Ћорић Б. Божо, Компаративна творба речи словенских језика, (Slawische Wortbildung im Vergleich: Theoretische und pragmatische Aspekte, Slavica Varia Halensia 12, Martin-Luther-Universität Halle-Wittenberg, red. Svetlana Mengel, Berlin, 2014, 681 str.), CJ XXI, 2016, 659-663 (приказ).

1179. Ćorić Božo, Serbian, ${ }^{130}$ in: Word-Formation. An International Handbook of the Languages of Europa, Volume 4 (Edited by Peter O. Müller, Ingeborg Ohnheiser, Susan Olsen, Franz Rainer), HSK 40.4, De Gruyter Mouton, Berlin/Boston, 2016, 3017-3037.

1180. Ћорић Божо, Из творбе ријечи у српском језику (О сложеницама), in: Зборник радова посвећен проф. др Милану Драгичевићу, Бања Лука 2018: Универзитет у Бањој Луци, Филолошки факултет, 63-70.

1181. Ćupić Drago, Lična imena u hronici „Kazivanja starih Trebješana”, Onomastica Jugoslavica 10, Zagreb, 1982, 23-28.

1182. Ћупић Драго, Микротопоними са суфиксом -ина у Бјелопавлићима, ППЈ 5, 1969, 303-307.

1183. Ћупић Драго, Микротопоними са суфиксом -ац $и$-ица у Бјелопавлићима, ППЈ 5 , 1969, 309-313.

1184. Ћупић Драго, Сложенице у бјелопавлићкој микротопонимији, in: Осма југословенска конференција и Други лингвистички скуп „Бошковићеви дани”, Подгорица, 1994, 228-232.

1185. Ћупић Драго, Деминутивна образоваға у Речнику говора Загарача, Четврти лингвистички скуп „Бошковићеви дани”, ЦАНУ, Подгорица, 1999, 123-131.

1186. Ујчић Тугомил, О називима за занатлиска и друга занимања, HJ V/3, 1937, $79-84$.

${ }^{130}$ Преглед творбе свих врста речи и свих творбених начина српског језика. 
1187. Utvić Miloš, Konačni automati u regularnoj imenskoj derivaciji, Magistarski rad, Beograd, 2008: Matematički fakultet u Beogradu.

1188. Фекете Егон, Дилеме око утврђивања лексичких форми неких типова српскохрватских придевских изведеница, in: Лексикографија и лексикологија, Нови Сад-Београд, 1984, 209-215.

1189. Фекете Егон, О ортографско-морфолошкој употреби и семантичко-лексичкој природи скраћеница, Преводилац IX/4, 1990, 11-18.

1190. Фекете Егон, O проблему nomina agentis feminina, Преводилац XI/1-4, Београд, 1992, 19-24.

1191. Фекете Егон, Суфиксални хипокористици образовани од антропонима мушког poдa, in: Осма југословенска ономастичка конференција и Други лингвистички скуп „Бошковићеви дани”, Подгорица, 1994, 233-242.

1192. Фекете Егон, Како именовати занимања и титуле женских особа, in: Егон Фекете, Језичке доумице, Београд, 2002, 81-90; Егон Фекете, Језичке доумице, новије и старије, Београд, 2006, 139-148. ${ }^{131}$

1193. Finka Božidar, O tvorbi nesvršsenih glagola s umecima -ava $i$-iva, J XIV/5, 1967, 141-144.

1194. Finka Božidar, Poimeničeni pridjevi u toponimiji zadarskog otočja, in: Осма југословенска конференција и Други лингвистички скуп „Бошковићеви дани”, Подгорица, 1994, 154-155.

1195. Franck O[tto], Studien zur serbokroatischen Ortsnamenkunde, Leipzig, 1932: Market \&. Petters.

1196. Frančić Vilim, Budowa slowotworcza serbochorwackich kolektywow, Krakow, 1961: Universytet.

1197. Frančić, Vilim, Ze studiow nad chorwackoserbskimi collectivami, Ivšićev zbornik, Zagreb, 1963, 61-66.

1198. Friščić Vinko, O pohrvaćenim pridjevima latinskog i grčkog podrijetla s obzirom na stručnu medicinsku terminologiju, J II/4, 1953-1954, 111-113.

1199. Friščić Vinko, Tvorba pridjeva hrvatskim domecima od imenica latinskog i grčkog podrijetla, J XVII/1, 1969, 11-20.

1200. Friščić Vinko, O riječima s grčkim predmetkom exo-, J XXXII/1, 1984, 6-10.

1201. Halonja Antun, Mihaljević Milica, Nazivi sa sastavnicom e- $u$ hrvatskome jeziku, ${ }^{132}$ Rasprave IHJJ 38/1, 2012, 55-86.

1202. Халупка Rешетар Сабина, Лалић Крстин Гордана, Нешто ново о новим сливенииама у српском језику, Свет речи 23-24, Београд, 2007, 26-30.

1203. Halupka Rešetar Sabina, Lalić Krstin Gordana, New blends in Serbian: typological and headedness-related issues, ГФФНС XXXIV/1, 2009, 115-124.

1204. Hamm Josip, Imenice s predmetkom pre-, J II, 4, 1953-1954, 97-102.

1205. Hadžiefendić Remzija, Deminucija i augmentacija u sistemu semantičkih kategorija, KJ 19/1, 1990, 29-33.

1206. Хаџиефендић Ремзија, Однос између квантификаиије и деминуниије/аугментаиије у српскохрватском језику, КЈ 20/1-2, 1991, 111-117.

\footnotetext{
${ }^{131}$ Популарно писан чланак, без научне апаратуре.

${ }^{132}$ Творбена и правописна питања у вези са сложеним формацијама са препозитивном компонентом e- (=електронски), као што су е-гласање, е-избори, е-картица, е-потпис и сл.
} 
1207. Хаџић Јован, ${ }^{133}$ єъык сРбскІй, Ображаванье Србски речій, ${ }^{134}$ Сербске лутописи V/18, Будим, 1829, 76-92. Прештампано као: Јован Хаџић, Језик сербскиј, Ображавање Србски речи, у: Мирослав Јовановић, Против Вука, Београд, 2004, $125-134$.

1208. Хлебец Борис, Придевске изведенице у значењу боје, СJ 3/1-2, 1998, 323-334.

1209. Хлебец Борис, О текстуалном понављану језлког садржаја, ${ }^{135}$ CJ XIX, 2014, $85-103$.

1210. Хлебец Борис, Реификаиија именице опасност, ${ }^{136}$ НССВД 35/1, 2006, 235-343.

1211. Horvat Joža, Prilog proučavanju imenske tvorbe: o tvorbenim načinima kojima od višerječnih toponima jedino izostavljanjem koje njihove sastavnice nastaju novi toponimi, ${ }^{137}$ Folia onomastica Croatica 27, Zagreb, 2018, 15-46.

1212. Horvat Marijana, Ramadanović Ermina, O tvorbi riječi u Tadijanovićevom djelu Svašta po malo, Rasprave IHJJ 33/1, 2007, 177-196.

1213. Horvat Marijana, Ramadanović Ermina, Tvorba glagola u djelu Svašta po malo Blaža Tadijanovića, Rasprave IHJJ 34, 2008, 133-153.

1214. Horvat Marijana, Štebih Golub Barbara, Globalizacija i internacionalizacija $u$ hrvatskome i srpskome jeziku, in: Branko Tošović (Hg.), Die Unterschiede zwischen dem Bosnischen/Bosniakischen, Kroatischen und Serbischen (Grammatik), Slawische Sprachkorrelationen 3, Wien/Berlin/Münster, 2010, 405-419.

1215. Horvat Marijana, Štebih Golub Barbara, Posljedice internacionalizacije u hrvatskome jeziku, ${ }^{138}$ Rasprave IHJJ 36/1, 2010, 1-21.

1216. Hraste Mate, O izvođenju etnika od geografskih imena, J I/1, 1952, 21-24.

1217. Hraste Mate, Stari grad, Starograđanin i starogradski, J I/3, 1952, 74-76.

1218. Hraste Mate, Dvojstvo oblika prisvojnih pridjeva $i$ zamjenica $n a-\mathrm{ov}$ (-ev) $i$-in $u$ hrvatskoj književnosti, PSKJ II/2, 1952, 190-198.

1219. Hraste Mate, O tvorbi posvojnih pridjeva na -ski od zemljopisnih imena, J II/2, 1953 $1954,47-49$.

1220. Hraste Mate, O ženskim prezimenima, J II/5, 1953-1954, 136-140.

1221. Hraste Mate, Sufiksi za tvorbu deminutiva i augemntativa u čakavskim govorima Srednje Dalmacije, Zbornik radova Filozofskog fakulteta II, Zagreb, 1954, 57-66.

1222. Hraste Mate, Tvorba imenica ženskog roda od stranih imena muškog roda sa završetkom -t, J V/ 4, 1957, 106-107.

1223. Hraste Mate, O značenju i upotrebi imenica na -ište, J VI/1, 1957-1958, 1-3.

1224. Hraste Mate, Tvorba etnika i ktetika u hrvatskosrpskom jeziku, J XII/4, 1965, 97-101.

1225. Цвијић Олга, О неким речима у преводу Новог завета, ЈФ XXVI/1-2, 19631964, 401-412.

1226. Цвијић Олга, Употреба суфикса -је у језику неких српских и хрватских романтичарских песника, НJ XV/5, 1966, 288-294.

${ }^{133}$ Чланак је потписан псеудонимом Светић М.

${ }^{134}$ Речи се деле на првобитне, производне и сложене. Међу производним су обрађени именички суфикси, а сложене речи нису обрађене. Наговештен је наставак (продолженије). Исп. Кашић Јован, 1985.

${ }^{135}$ Поред осталог и о моцији (добра и лоша страна употребе мовираних фемининума).

${ }^{136}$ Поред осталог и о необичној морфолошкој структури придева безопасан.

${ }^{137}$ О стварању топонима путем елипсе.

${ }^{138}$ На грађи писаних медија и интернетских извора истражују се деривати са страним префиксоидима и суфиксоидима, јукстапозиционе формације, суфикс -изација, те полисемне позајмљенице. 
1227. Цвијић Олга, ${ }^{139}$ Однос основе и наставака -овати, -исати, -ирати глагола страног порекла, ${ }^{140} \mathrm{HJ} \mathrm{XVIII} / 3,1970,131-161$.

1228. Цвитковић Мислав, Neostvareno tvorbeno-semantičko gnijezdo naziva kosa, J 61/4-5, 2014, 165-174.

1229. Zett Robert, O problematici složenica tipa nogomet, J XVI/4, 1969, 103-110.

1230. Zett Robert, Beiträge zur Geschichte der Nominalkomposite im Serbokroatishen, Die altserbische Periode, Köln-Wien, 1970, I-VII + 1-335.

1231. Cichońska Maria, Префиксално-суфиксални деноминативни глаголи у савременом српскохрватском књижевном језику, НССВД 16/1, 1987, 75-80.

1232. Црепајац Љиљана, Прилог проучавању грчких семантичких позајмљеница и преведеница у српскохрватском, Жива антика 28, Београд, 1978, 75-84.

1233. Црепајац Љиљана, Прилог проучавағу грчких модела српскохрватске антропонимије, ОП I, 1979, 69-74.

1234. Чампар Драгован, Даничићев прилог проучавағу именичких деминутива и аугментатива, НССВД 5, 1976, 677-688.

1235. Чампар Драгован, Ограничењ а у творби и употреби именичких аугментатива у руском и српскохрватском језику, Studia philologica, књига II/1-2, Приштина, 1981, 141-160.

1236. Чампар Драгован, Род и број именичких аугментатива у српскохрватском јези$\kappa y$, НССВД 13/1, 1984, 289-300.

1237. Чампар Драгован, Именички деминутиви у језичким афоризмима Вука Караиића, НССВД 17/2, 1984, 275-281.

1238. Чорболоковић С. Саша, Деадјективна nоmina loci у српском језику, Књ L LX/1, 2013, 53-62.

1239. Чорич Божо, Инвентар на афиксите в сръбския език, in: Слово и словесност. Сборник в чест на доц. д-р Юлия Балтова, София, 2010: ИК Емас, 322-328.

1240. Џоговић Алија, Букумирић Милета, Систем личних имена код српског становништва у Клини и Дрснику у Метохији, Onomastica Jugoslavica 10, Zagreb, 1982, $35-30$

1241. Шакић Јања, Придеви са суфиксом -ив/-љив у српскохрватском језику, ППЈ 1, $1965,75-100$

1242. Шакић Јања, Прилог библиографији радова о творби речи у српскохрватском језику, ППЈ 2, 1966, 239-259.

1243. Šarić Ljiljana, Neke značenjske i tvorbene odrednice, ${ }^{141}$ RZJ 18, 1992, 177-191.

1244. Šarić Ljiljana, Antonimija u hrvatskome jeziku: semantički, tvorbeni i sintaktički opis ${ }^{142}$ Zagreb, 2007: Hrvatska sveučilišna naklada.

1245. Šarić Ljiljana, The verbal prefix na- in Croatian: A cognitive linguistic analysis, ${ }^{143} \mathrm{SL}$ 75, 2013, 45-74.

${ }^{139}$ У садржају стоји Олга Ристић.

${ }^{140}$ На изузетно богатој грађи утврђују се фонетски, генетски и семантички фактори који утичу на дистрибуцију суфикса у односу на основу.

${ }^{141}$ Поред осталог и о антонимији у префиксалној деривацији.

${ }^{142}$ Још једном, у књизи, и о антонимији у префиксацији глагола, придева и именица.

${ }^{143} \mathrm{O}$ глаголском префиксу на- у когнитивнолингвистичким оквирима. На основу опсежног инвентара савремених глагола испитују се семантичке карактеристике свих значењских подскупина глагола с префиксом на-. 
1246. Šarić Ljiljana / Nedelcheva Svetlana, The verbal prefix o(b)- in Croatian and Bulgarian: The semantic network and challenges of a corpus-based study, ${ }^{144}$ SL 80, 2015, 149-179.

1247. Šarić Ljiljana, A semantic analysis of the verbal prefix o(b)- in Croatian, Croatica et Slavica Iadertina XI/2, Zadar, 2015, 249-283.

1248. Šehović Amela, Univerbacija u bosanskom jeziku, in: Творба речи и њени ресурси у словенским језицима, Зборник радова са четрнаесте међународне научне конференције Комисије за творбу речи Међународног комитета слависта, Београд, 2012: Филолошки факултет, 407-417.

1249. Šehović Amela, Pragmatički aspekti deminucije u svakodnevnoj komunikaciji (sa osvrtom na tvorbena obilježja deminutivnih imenica), in: Stramljič Breznik Irena (ured.), Manjšalnice v slovanski jezikih: oblika in vloga, Maribor, 2015, 375-385.

1250. Šehović Amela, Skraćivanje riječi na internetskim forumima, in: Branko Tošović, Arno Wonisch (Hg.), Wortbildung und Internet: Institut für Slawistik der KarlFranzens-Universität Graz, Kommission für Wortbildung beim Internationalen Slawistenkomitee, Graz, 2016, 405-418.

1251. Šimpraga Čilaš Ankica, Kurtović Budja Ivana, Etnici i ktetici u kajkavskom narječju, Rasprave IHJJ 35, 2009, 35-52.

1252. Šimpraga Čilaš Ankica, Etnici i ktetici u Drniškoj krajini, FOC 21, Zagreb, 2012, $17-36$.

1253. Šimundić Mate, Tvorba osobnih imena u hrvatskome ili srpskome jeziku, Maribor, 1970.

1254. Šimundić Mate, Sufiksalni morfem -ul/-ulo/-ula u slovenskim jezicima, Прва југословенска ономастичка конференција, ЦАНУ, Титоград, 1976, 179-185.

1255. Šimunović Petar, Tipološko-strukturalni ogled istarske ojkonimije, RZJ IV-V, 1979 , 219-249.

1256. Šimunović Petar, Ojkonimija općine Dvora na Uni, RZJ XVII, 1991, 243-277.

1257. Šivić Dular Alenka, Južnoslovanski priimki s pripono -(j)ava, Onomastica Jugoslavica 10, Zagreb, 1982, 239-246.

1258. Šipka Danko, Jedan neregistrirani sufiks, J XXXV/3, 1988, 94.

1259. Šipka Danko, Tvrobena sredstva antonimizacije, J XXXVII/5, 1989, 139-145.

1260. Шипка Данко, O српскохрватским скраћеницама - теоријско полазиште нормирања, Књ ХXXVII/2, 1990, 140-146.

1261. Šipka Danko, Distribucija nastavka -irati/-isati/-ovati u srpskim glagolima stranog porijekla, ЗбМСФЛ XLIV/1-2, 2001, 167-173.

1262. Šipka Danko, Rečnik tvorbenih formanata, Beograd, 2003: Алма.

1263. Šipka Danko, Glosar tvorbenih formanata, Beograd, 2005: Алма.

1264. Šipka Milan, Posvojni pridjevi od ličnih imena i prezimena, J VI/4, 1958, 107-113.

1265. Šipka Milan, Kozaračko ili kozarsko kolo?, J VII/1 1958/1959, 29-30.

1266. Šipka Milan, Narodni i stručni nazivi za bolesnike, J IX/4, 1961-62, 120-126.

1267. Šipka Milan, Tvorba i značenje imenica na -ivo, J X/3, 1962-1963, 76-81.

1268. Šipka Milan, Vozač ili vozar?, J X/2, 1962-1963, 61-63.

1269. Шипка Милан, Род и број скраћеница у српскохрватском језику, ${ }^{145}$ НССВД $13 / 1$, 1984, 197-203.

1270. Шипка Милан, Сендвичара, палачинкара и печењьара, ЈД 2, 1997, 11-13.

\footnotetext{
${ }^{144} \mathrm{O}$ глаголском префиксу $о(б)-$ у два јужнословенска језика из перспективе когнитивне лингвистике, на речничкој и корпусној грађи.

${ }^{145} \mathrm{O}$ лексикализованим и нелексикализованим скраћеницама са граматичког аспекта.
} 
1271. Шипка Милан, „, Козарачко коло” и норма, ЈД 12, 2000, 21-23. Прештампано у: Милан Шипка, Стандарднојезичка преиспитивања I, Нови Сад, 2008: Прометеј, 205-213.

1272. Шипка Милан, $O$ ктетицима српски и србијански у свјетлу лексичко-семантичке норме, НJ XXXIV, 2001, 111-122.

1273. Шипка Милан, Придеви с наставком -иони, НJ 35/1-4, 2004, 30-45. Прештампано у: Милан Шипка, Стандарднојезичка преиспитивања I, Расправе, Нови Сад, 2008: Прометеј, 144-173.

1274. Шипка Милан, Творба, значење и деклинација именица на -ист(а), НJ XXXIX/14, 2008, 19-34.

1275. Шипка Милан, O супстантивизачији адверба у српском језику, in: Милан Шипка, Стандарднојезичка преиспитивања 1, Расправе, Нови Сад, 2008: Прометеј, 109-128.

1276. Šojat Antun, Pridjevski nastavci -iv $i$-ljiv, F 2, 1959, 93-110.

1277. Škarić Đuro, Srpskohrvatske os-riječi, Rad JAZU 260, 169-198.

1278. Штасни Гордана, Неологизми, кованице и индивидуално означавање речи у Речнику српскохрватског къижевног језика, ППЈ 28-29, 1997, 87-118.

1279. Штасни Гордана, Nomina agentis $u$ nomina attributiva y Речнику српскохрватског къижевног језика, ППЈ 30-32, 1999-2001, 285-296.

1280. Штасни, Гордана, Префиксаиија - у светлу савремених теорија о творби речи и у основношколским уибеницима, in: Неговање српског језик и књижевности, Нови Сад, 2006, 175-197.

1281. Штасни Гордана, Nomina loci са називом биљке у творбеној основи, ЗбМСФЛ L/1-2, 2007, 927-938.

1282. Штасни Гордана, Деривати на -ица од назива људског тела, ППЈ 38, 2007, $93-$ 106.

1283. Штасни Гордана, Генитивне предлошке конструкиије у основи именичких деpuвama, in: Синтаксичка истраживања (дијахроно-синхрони план), Нови Сад, 2007, 253-264.

1284. Штасни Гордана, Творба речи у настави српског језика. Творбени процеси: илустративни примери и вежбе (неки теоријски и практични проблеми), in: Зборник радова: Унапређивање наставе српског језика и књижевности, Нови Сад, 2007, 102-118.

1285. Штасни Гордана, Атрибутивне именице (nomina attributiva) у српском језику, СJ XII/1-2, 2007, 469-483.

1286. Штасни Гордана, Творба речи у настави српског језика, Београд, 2008: Друштво за српски језик и књижевност.

1287. Штасни Гордана, Творба речи и сродне дисциплине, in: Тумачење књижевног дела и методика наставе, део 2, Нови Сад, 2009, 411-419.

1288. Штасни Гордана, Деривациони статус мотивисаних лексема, ГФФНС 35/2, 2010, 381-391.

1289. Штасни Гордана, Мотиваџиони смерови у деривационим проиесима, ЗбМСФЛ LIII/ 2, 2010, 89-97.

1290. Штасни Гордана, Семантичко-деривациони потенцијал глагола основних физиолошких стаға, in: Граматика и лексика у словенским језицима (Зборник радова са научног симпозијума), Нови Сад - Београд, 2011, 576-584.

1291. Штасни Гордана, Деминутивни супстантиви са диферениијалном семом човек у Вуковом Српском рјечнику (1818), НССВД 40/1, 2011, 289-301. 
1292. Штасни Гордана, Семантичко-деривациони потенцијал именица из лексичке групе животиъ $a$, in: Лексикологија, ономастика, синтакса (Зборник у част Гордане Вуковић), Нови Сад, 2011, 307-317.

1293. Штасни Гордана, Номиначија човека мотивисана позитивним карактерним особинама, ЗбМСФЛ, LIV/1, 2011, 167-180.

1294. Штасни Гордана, Ајџановић Милан, Становници Новог Сада и Петроварадина: деривачиони модели и употребна норма, in: Говор Новог Сада, св. 2: Морфосинтаксичке, лексичке и прагматичке особине, Нови Сад, 2011,78-120.

1295. Штасни Гордана, Ајџановић Милан, Како ученици именују становнике Новог Cada, in: Говор Новог Сада, св. 2: Морфосинтаксичке, лексичке и прагматичке особине, Нови Сад, 2011, 121-153.

1296. Штасни Гордана, Ајџановић Милан, Деривациони модели именица nomina agentis y говору Новог Сада, in: Говор Новог Сада, св. 2: Морфосинтаксичке, лексичке и прагматичке особине, Нови Сад, 2011, 154-181.

1297. Штасни Гордана, Семантичко-деривачионе карактеристике суфикса -ун(а)ц, ЗбМСФЛ LV/1, 2012, 211-219.

1298. Штасни Гордана, Етници у Вуковом Српском рјечнику (1852) и лексичко-семантичка норма, НССВД 41/1, 2012, 309-318.

1299. Штасни Р. Гордана, Нерегистроване глаголске именице у српском језику, ГФФHC XXXVII/2, 2012, 301-321.

1300. Штасни Гордана, Утиияј семантичког садржаја на дериваиију глагола физиолошких стаға и проиеса, in: Творба речи и њени ресурси у словенским језицима, Зборник радова са четрнаесте међународне научне конференције Комисије за творбу речи Међународног комитета слависта, Београд, 2012: Филолошки факултет, 745-755.

1301. Штасни Гордана, Реч о човеку (номинација човека у српском језику), ${ }^{146}$ Нови Сад, 2013: Филозофски факултет.

1302. Штасни Гордана, Бошњаковић Жарко, Сложенице са компонентама љуб-/-љуб-

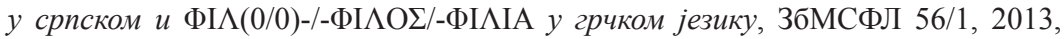
129-152. ком вијенц

1303. Штасни Р. Гордана, Штрбац Р. Гордана: Именички англицизми на -ер у српском језику, ЈФ LXXI/1-2, 2015, 43-67.

1304. Штасни Р. Гордана, Деривати са суфиксом -ина мотивисани соматизмима, КњJ LXVIII/3-4, 2016, 243-252.

1305. Штасни Р. Гордана, Суфиксална синонимија у српскм језику, ${ }^{147}$ in: ПУТЕВИМА РЕЧИ, Зборник радова у част Даринки Гортан Премк, Уредник Рајна Драгићевић, Београд, 2017: Филолошки факултет у Београду, 387-398.

1305. Štebih Barbara, Transmorfemizacija imeničkih germanizama u kajkavskome književnom jeziku, Rasprave IHJJ 32, 2006, 295-311.

1307. Štebih Golub Barbara, Hibridne složenice u kajkavskome književnom jeziku, Rasprave IHJJ 33, 2007, 391-417.

1308. Štebih Golub Barbara, Pravi tvorbeni mocijski parnjaci u kajkavskome književnom jeziku, Rasprave IHJJ 34, 2008, 393-412.

1309. Štebih Barbara, Tvorbeni obrasci neologizama u hrvatskome standardnom jeziku, in: Словообразуване и лексикология, София, 2009, 364-275.

1310. Štebih Golub Barbara, Prefiks ne- $u$ kajkavskome književnom jeziku, Rasprave IHJJ 35, 2009, 333-345.

\footnotetext{
${ }^{146} \mathrm{O}$ персоналним nomina attributiva, пре свега.

${ }^{147} \mathrm{O}$ афиксалној синонимији у категорији nomina agentis masculinum.
} 
1311. Štebih Barbara, Složenice u kajkavskome književnom jeziku, in: Відображення icторії та культури народу в словотворенні, Доповіді ХІІ Міжнародної наукової конференції Комисії зі слов'янського словотворення при Міжнародному комітеті славістів, Київ, 2010, 329-343.

1312. Štebih Golub Barbara, Okazionalizmi u hrvatskome publicističkom stilu, in: Tворба речи и њени ресурси у словенским језицима, Зборник радова са четрнаесте међународне научне конференције Комисије за творбу речи Међународног комитета слависта, Београд, 2012: Филолошки факултет, 419-433.

1313. Štebih Golub Barbara, O mociji bez emocija, ${ }^{148}$ CJ XIX, 2014, 461-478.

1314. Štebih Golub Barbara, Hrvatsko rječoslovlje - između tradicije i novih potreba, in: Swetlana Mengel (Hg.), Slavische Wortbildung im Vergleich, Theoretische und pragmatische Aspekte, Berlin 2014, 462-477.

1315. Штрбац Гордана, Деривација именица са значењем лица у делима Стефана Првовенчаног, ППЈ 56, 2005, 5-30.

1316. Штрбац Гордана, Деривациони потенцијал афективних глагола, in: Творба речи и њени ресурси у словенским језицима, Зборник радова са четрнаесте међународне научне конференције Комисије за творбу речи Међународног комитета слависта, Београд, 2012: Филолошки факултет, 757-771.

\section{3. Скраћенице}

\begin{tabular}{|c|c|}
\hline АФФ & Анали Филолошког факултета, Београд \\
\hline ГБС & Градска библиотека Суботииа \\
\hline Гласник & Гласник Одјељењь умјетности, ЦАНУ, Подгорица \\
\hline Глас САНУ & Глас Српске академије наука и уметности, Београд \\
\hline Глас СКА & Глас Српске краљевске академије, Београд \\
\hline ГФФНС & Годишъак Филозофског факултета, Нови Сад \\
\hline ДСЈК & Друштво за српски језик и књижевност, Београд \\
\hline ЗбМСФЛ & Зборник Матице српске за филологију и лингвистику, Нови Сад \\
\hline ЗУНС & Завод за уибенике и наставна средства, Београд \\
\hline ИСЈ САНУ & $\begin{array}{l}\text { Институт за српски језик Српске академије наука и умет- } \\
\text { ности, Београд }\end{array}$ \\
\hline $\mathrm{J}$ & Jezik, Zagreb \\
\hline
\end{tabular}

148 О употреби мовираних фемининума и женских презименских варијаната. Описују се актуелне друштвене расправе о тој теми, стање у легислативи и ставови језикословаца. На основу истраживања спроведеног у штампаним и електронским медијима и циљаним упитником, доносе се закључци о уобичајености и учесталости мовираних фемининума, ставовима говорника о њима, употреби именица мушкога рода као генеричког облика, те о женским презименским варијантама. 


\begin{tabular}{|c|c|}
\hline ЈД & Језик данас, Нови Сад \\
\hline $\mathrm{J} \Phi$ & Јужнословенски филолог, Београд \\
\hline KJ & Književni jezik, Sarajevo (и ћирилицом) \\
\hline Књ J & Кюижевност и језик, Београд \\
\hline NV & Nastavni vjesnik, Zagreb \\
\hline HJ & Наш језик, Београд (предратна серија и нова серија) \\
\hline НССВД & Научни састанак слависта у Вукове дане, Београд \\
\hline ОП & Ономатолошки прилози, Београд \\
\hline Пл & Примењена лингвистика, Нови Сад \\
\hline ППЈ & Прилози проучавағу језика, Филозофски факултет, Нови Сад \\
\hline PSKJ & Pitanja savremenog književnog jezika, Sarajevo \\
\hline Rad JAZU & Rad Jugoslavenske akademije znanosti i umjetnosti, Zagreb \\
\hline $\begin{array}{l}\text { Radovi } \\
\text { ANU BiH }\end{array}$ & Radovi Akademije nauka i umjetnosti BiH, Sarajevo \\
\hline $\begin{array}{l}\text { Rasprave } \\
\text { IHJJ }\end{array}$ & Rasprave Instituta za hrvatski jezik i jezikoslovlje, Zagreb \\
\hline RZJ & Rasprave Zavoda za jezik, Zagreb \\
\hline RZSF & Radovi Zavoda za slavensku filologiju, Zagreb \\
\hline RFFS & Radovi Filozofskog fakulteta, Sarajevo \\
\hline $\mathrm{C}$ & Славистика, Београд \\
\hline CJ & Српски језик, Београд \\
\hline SL & Suvremena lingvistika, Zagreb \\
\hline $\mathrm{F}$ & Filologija, Zagreb \\
\hline FOC & Folia onomastica croatica, Zagreb \\
\hline ČR & Čakavska rič, Split \\
\hline ČJOK & Četrta jugoslovanska onomastična konferenca, Ljubljana, 1981. \\
\hline
\end{tabular}


Božo B. ĆORIĆ

NEW CONTRIBUTION TO THE BIBLIOGRAPHY OF WORD-FORMATION

Summary

The bibliography contains the works on word-formation written by scholars and grammarians during the period of almost two centuries (from the first half of $19^{\text {th }}$ Century until now). It includes the monographs, studies, articles, polemics, grammars, critiques, reviews, miscellanea etc. The main part of bibliographic entries is collected from the South-Slavic area that in past was identified by different glottonyms: Serbian language, Serbo-Croatian language, Serbian or Croatian, Croatian or Serbian, Croatian etc. A part of data was taken also from publications that originated outside of this space, in various Slavistic academic centers. Among the authors are not only the native Serbists (and/or SerboCroatists), but also the native Slavists of other orientations (Russists, Polonists, Bohemists, Bulgarists etc.), as well as foreign scholars who studied the questions of Serbian, resp. Serbo-Croatian wordformation. Likewise, all more important grammars of Serbian and Croatian (resp. Serbo-Croatian) language in which the word-formation is distinguished as a particular entity are included into the list. Neither the works of contrastive (confrontative) nature are not ommited from the list, whenever the authors included, in this or that measure, the phenomena of Serbian (Serbo-Croatian) word-formation. This bibliographical material is important not merely for the Serbian language researchers (to whom it is primarily dedicated), but also for all other academic centers, which inherit, in larger or smaller measure, the results of linguistic researches in the field of word-formation in the central South-Slavic areas. 